\title{
ПОТРЕБЛЕНИЕ НАРКОТИКОВ, ПСИХОТРОПНЫХ ВЕЩЕСТВ, ТОКСИКОМАНИЯ, АЛКОГОЛИЗМ И КУРЕНИЕ ТАБАКА - ОБЩЕСТВЕННОЕ И ГОСУДАРСТВЕННОЕ БЕДСТВИЕ, ЕГО АНАЛИЗ И ПУТИ ПРЕОДОЛЕНИЯ Э.И. Слепян
}

Санкт-Петербургский лесотехнический университет, Санкт-Петербург, Россия Эл.nочma: slepyan@21mm.ru

Статья поступила в редакцию 21.10.2016; принята к печати 05.12.2016

Статья посвящена многостороннему рассмотрению наркотизма, потребления психотропных препаратов, токсикомании, алкоголизма и курения - противоправных пристрастий, опасных как для отдельного человека, так и для общества и государства, и содержит рекомендации по преодолению упомянутых пристрастий.

Ключевые слова: наркотизм, психотропные препараты, токсикомания, алкоголизм, курение.

\author{
DRUGS AND PSYCHOTROPIC SUBSTANCES ABUSE, TOXICOMANIA, \\ ALCOHOLISM, AND SMOKING AS SOCIAL AND NATIONAL CALAMITY: \\ ANALYSIS OF AND WAYS TO OVERCOME IT \\ E.I. Slepyan \\ Saint-Petersburg State Forestry University Saint Petersburg, Russia \\ E-mail: slepyan@21mm.ru
}

The article focuses on multilateral analisis of psychotropic substances use, toxicomania, alcoholism and smoking - illegal propensities, which are dangerous for society and government - and suggests ways to overcome them.

Keywords: narcotism, psychotropic substances, toxicomania, alcoholism, smoking.

\section{Введение}

Невозможно привести более убедительный пример свидетельства войны против человечества, чем распространяющаяся по всем континентам подобно пандемии наркомания - следствие потребления природных и синтетических соединений с психотропным и наркотическим действием [61, 98, 267]. Наркомания (наркотизм) приобрела значение проблемы особой социальной аномалии (по существу, социальной катастрофы) для всех народов и любых государств [6, $15,19,102,108,117,184,191,193.328]$.

В обществе XX и XXI столетий наркомания затронула многие семьи в разных странах [326]. Известны так называемые первая, вторая и третья «наркофильные революции», связанные с психоделическими переживаниями [115]. Ни на одном континенте не существуют поселения человека, в которых наркомания не может появиться. Так называемый наркоиммунитет регионов криминалистически, клинически и социологически не подтвержден [309, 317]. У наркоманов, токсикоманов, алкоголиков, практически у всех личностей с противоправными наклонностями и поведением обычен эмоциональный стресс, требующий, как правило, психофармакологического вмешательства.

Чрезвычайно важная проблема, следовательно, единовременное или близкое по срокам выполнение социологических, криминалистических, юридических и клинических анализов с соответствующей последующей оценкой наркоситуации на каждой самостоятельной и более или менее административно и географически обособленной территории (в админи- стративной области, в городской агломерации, в городе и во внегородских поселениях) и, вслед за такими анализом и оценкой, сопоставление фактических наркоситуаций с целью установления их общего состояния и тенденций изменения как в пространстве, так и во времени $[28,96,263]$. Очевидно, что исследование наркоситуаций требует сравнительного контроля и комплексного мониторинга. Именно такая методология - объективная необходимость, во-первых, в связи с постоянным имеющем место наркотрафиком $[77,96]$ и, во-вторых, в связи с контрабандой наркотиков как природного происхождения (фитогенных, зоогенных, микогенных и т. д.), так и искусственно созданных - продуктов химического синтеза и компьютерного молекулярного конструирования.

Внутригосударственный и межгосударственный наркотрафик приводит к обоснованной необходимости обращать повышенное внимание и на проблему экологического терроризма, который, в частности, вполне реален в транспортной сети, используемой для наркотрафика [258, 261-263, 265, 266].

\section{Наркотики и их действие}

В списке Всемирной организации здравоохранения (ВО3), содержащем перечень лекарств, применяемых как наркотики и подлежащих международному контролю, указывается на следующие лекарственные средства, число которых девяносто [193].

1. Ацетилдигидрокодеин (ацетилдигидрокодеин).

2. Ацетилметадол (3-ацетокси-6-диметиламино-4,4-дифенилгептан). 
3. Аллилпродин (3-аллил-1-метил-4-фенил-4-пропионоксипиперидин).

4. Альфаацетилметадол (а-3-ацетокси-6-диметил/ амино-4,4-дифенилгептан).

5. Альфамепродин ( $\alpha-3$-этил-1-метил-4-фенил-4пропионоксипиперидин).

6. Альфаметадол ( $\alpha$-6-диметиламино-4,4-дифенил3-гептанол).

7. Альфапродин ( $\alpha-1,3$-диметил-4-фенил-4пропионоксипиперидин).

8. Анилеридин (этиловый эфир 1-(р-аминофенетил)4-фенилпиперидин-4-карбоксильной кислоты).

9. Бензетидин (этиловый эфир 1-(2-бензилоксиэтил)-4-фенилпиперидин-4-карбоксильной кислоты).

10. Бензилморфин (3-бензилморфин).

11. Бетацетилметадол ( $\beta$-3-ацетокси-6диметиламино-4,4-дифенилгептан).

12. Бетамепродин ( $\beta$-3-этил-1-метил-4-фенил-4пропионоксипиперидин).

13. Бетаметадол ( $\beta-6$-диметиламино-4,4-дифенил3-гептанол)

14. Бетапродин ( $\beta-1,3$-диметил-4-фенил-4пропионоксипиперидин).

15. Каннабис (Cannabis sativa L.).

16. Клонитазен (2- - -хлорбензил-1-диэтиламиноэтил-5-нитробензимидазол).

17. Кокаин (метиловый эфир бензоилекгонина).

18. Кодеин (3-метилморфин). Сообщается и об ином молекулярном составе кодеина - ((5a, 6a)-7,8-дидегидро-4,5-эпокси-3-метокси-17-метилморфинан-6-ол), приводимом в статье о тропикамиде [62].

19. Дезоморфин (дигидродеоксиморфин).

20. Декстроморамид ((+)-4-[2-метил-4-оксо-3,3-дифенил-4-(1-пирролидинил) бутил] морфолин).

21. Диампромид (N-[2-(метилфенетиламино)пропил]-пропионанилид).

22. Диэтилтиамбутен (3-диэтиламино-1,1-ди(2'тиэнил)-1-бутен).

23. Дигидрокодеин (7,8-дигидрокодеин).

24. Дигидроморфин (7,8-дигидроморфин).

25. Левоморамид ((-)-4-[2-метил-4-оксо-3,3-дифенил-4-(1-пирролидинил)-бутил] морфолин).

26. Левофенацилморфан ((-)-3-гидрокси-N-фенацил-морфинан).

27. Леворфанол ((-)-3-гидрокси-N-метил-морфинан).

28. Метазоцин (2'-гидрокси-2,5,9-триметил-6,7бензоморфан)

29. Метадон (6-диметиламино-4,4-дифенил-3-гептанон).

30. Метадон-интермедиат (4-циано-2-диметиламино-4,4-дифенилбутан).

31. Метилдезорфин (6-метил $\Delta^{6}$-деоксоморфин).

32. Метилдигидроморфин (6-метилдигидроморфин).

33. Метопон (5-метилдигидроморфинон).

34. Морамил-интермелиат (2-метил-3-морфолино-1,1-лифенилпропан-карбоксильная кислота).

35. Морферидин (этиловый эфир 1-(2-морфолиноэтил)-4-фенилпиперидин-4-карбоксильной кислоты).

36. Морфин.

37. Морфин-N-оксид.

38. Мирофин (миристилбензилморфин).

39. Никоморфин (3,6-диникотинилморфин).
40. Нароциметадол $(( \pm)-\alpha-3$-ацетокси-6-метиламино-4,4-дифенилгептан).

41. Дименоксадол (2-диметиламиноэтил 1-этокси-1,1-дифенилацетат).

42. Димефептанол (6-диметиламино-4,4-дифенил3-гептанол).

43. Диметилтиамбутен (3-диметиламино-1,1-ди (2'-тиэнил) 1 -бутен).

44. Диоксафетилбутират (этил-4-морфолино-2,2дифенилбутират).

45. Дифеноксилат (этиловый эфир 1-(3-циано-3,3дифенилпропил)-4-фенилпиперидин-4-карбоксильной кислоты).

46. Дипипанон (4,4-дифенил-6-пиперидин-3-гептанон).

47. Экгонин ((-)-3-гидрокситропан-2-карбоксилат).

48. Этилметил-тиамбутен (3-этилметиламино-1,1ди (2'-тиэнил)-1-бутен).

49. Этилморфин (3-этилморфин).

50. Этонитазен (1-диэтиламиноэтил-2- $\rho-$ этоксибензил-5-нитробензимидазол).

51. Этоксеридин (этиловый эфир

1-[2-(2-гидроксиэтокси)-этил]-4-фенилпиперидин4-карбоксильной кислоты).

52. Фуретидин (этиловый эфир 1-(2-тетрагидрофурфурилоксиэтил)-4-фенилпиперидин-4-карбоксильной кислоты).

53. Героин (диацетилморфин).

54. Гидрокодон (дигидрокодеинон).

55. Гидроморфинол (14-гидроксидигидроморфин).

56. Гидроморфон (дигидроморфинон).

57. Гидроксипетидин (этиловый эфир 4-(m-гидроксифенил0-1-метилпиперидин-4-карбоксильной кислоты).

58. Изометадон (6-диметиламино-5-метил-4,4-дифенил-3-гексанон).

59. Кетобемидон (4-(m-гидроксифенил)-1-метил4-пропионилпиперидин).

60. Левометорфан ((-)-3-метокси-N-метилформинин).

61. Норкодеин (N-диметилкодеин).

62. Норлеворфанол ((-)-3-гидроксиморфинан).

63. Норметадон (6-диметиламино-1,1-дифенил3-гексанон).

64. Норморфин (диметилморфин).

65. Опиум.

66. Оксикодон (14-гидроксидигидрокодеинон).

67. Оксиморфон (14-гидроксидигидроморфинон).

68. Петидин (этиловый эфир 1-метил-4-фенилпиперидин-4-карбоксильной кислоты).

69. Петидин-интермедиат-А (4-циано-1-метил4-фенилпиперидин)

70. Петидин-интермедиат-В (этиловый эфир 4-фенилпиперидин-4-карбоксильной кислоты).

71. Фенадоксон (6-морфолино-4,4-дифенил-3-гептанон).

72. Фенампромид (N-(1-метил-2-пиперидин-этил) пропионанилид).

73. Феназоцин (2'-гидрокси-5,9-диметил-2-фенетил-6,7-бензоморфан).

74. Феноморфан (3-гидрокси-N-фенетил-морфинан).

75. Феноперидин (этиловый эфир 1-(3-гидрокси3-фенилпропил)-4-фенилпиперидин-4-карбоксильной кислоты).

76. Фолкодин (морфолинилэтилморфин). 
77. Пиминодин (этиловый эфир 4-фенил-1-(3фениламинопропил)-пиперидин-4-карбоксильной кислоты).

78. Прогептазин (1,3-диметил-4-фенил-1-пропионоксиазациклогептан).

79. Проперидин (изопропиловый эфир 1-метил4-4-фенилпиперидин-4-карбоксильной кислоты).

80. Рацеметорфан (( \pm$)-3$-метокси-N-метилморфинан).

81. Рацеморамид (( \pm -4-[2-метил-1-оксо-3,3-дифенил-4-(1-пирролидинил)-бутил] морфолин).

82. Рацеморфан (( \pm$)-3$-гидрокси-N-метил-морфинан).

83. Тебакон (ацетилдигидрокодеинон).

84. Тебаин (3,6-диметил-8-дегидроморфин).

85. Тримеперидин (1,2,5-триметил-4-фенил-4-пропионоксипиперидин).

86. Фентанил (1-фенетил-4-N-пропиониланилинопиперидин).

87. Никокодин (6-никотинилкодеин).

88. Норпипанон (4,4-дифенил-6-пиперидино-гексанон).

89. Петидин-интермедиат C (1-метил-4-фенилпиперидин-4-карбоксильная кислота).

90. Пиритрамид ((3-циано-3,3-дифенилпропил)4-(1-пиперидино)-пиперидин-4-карбоксильной кислоты амид) [207].

В этот список должен быть добавлен тропикамид, представляющий собой $\mathrm{N}$-этил-3-тирокси-2-фенил$\mathrm{N}$-пиридил-4-илметил-тропикамид [62].

Экспертами ВОЗ приведена классификация психотропных веществ [22]:

\begin{tabular}{|c|c|}
\hline Категория & $\begin{array}{c}\text { Характерные } \\
\text { представители }\end{array}$ \\
\hline $\begin{array}{l}\text { Нейролептические } \\
\text { средства }\end{array}$ & $\begin{array}{l}\text { Фенотиазины } \\
\text { Бутирофеноны } \\
\text { Тиоксантены } \\
\text { Производные резерпина } \\
\text { Бензохинолизины }\end{array}$ \\
\hline $\begin{array}{l}\text { Седативные средства, } \\
\text { снижающие чувство } \\
\text { беспокойства }\end{array}$ & $\begin{array}{l}\text { Мепробамат и его } \\
\text { производные } \\
\text { Диазепоксиды } \\
\text { (бензодиазепины) } \\
\text { Барбитураты }\end{array}$ \\
\hline Психостимуляторы & $\begin{array}{l}\text { Амфетамин, метилфенидат, } \\
\text { пипрадрол, кофеин }\end{array}$ \\
\hline Антидепрессанты & $\begin{array}{l}\text { Ингибиторы } \\
\text { моноаминоксидазы (MOA) } \\
\text { Имипрамин и другие } \\
\text { трициклические соединения }\end{array}$ \\
\hline $\begin{array}{l}\text { Психодислептические } \\
\text { средства } \\
\text { (галлюциногены) }\end{array}$ & $\begin{array}{l}\text { Диэтиламид лизергиновой } \\
\text { кислоты (ДЛК) Мескалин } \\
\text { Псилоцибин } \\
\text { Диметилтриптофан (ДМТ) } \\
\text { Индийская конопля } \\
\text { (марихуана, гашиш и т. д.) }\end{array}$ \\
\hline
\end{tabular}

К антинаркотическим проблемам международного значения принадлежат, во-первых, проблема обоснования российской и всемирной антинаркотической политики [123, 169, 301, 302, 316]; во-вторых, проблема обоснования антинаркотической безопасности; втретьих, проблема предупреждения чрезвычайных ситуаций, которые могут быть инициированы наркоманами, например, на потенциально опасных объектах - атомных электрических станциях и т. д. [124], причем необходимо учесть, что наркоманы, токсикоманы и криминальные личности вообще способны инициировать акты экологического терроризма [194, 195, 261-263, 265, 266]; в-четвертых, проблема лечения и социальной реабилитации наркоманов [133]; в-пятых, проблема токсичности наркотиков по сравнению с токсичностью не психотропных снадобий и с учетом критических периодов развития организма человека, его пола, возраста и состояния здоровья, кинетики выведения из организма и разрушения в нем $[4,5,107,131,164,165,168]$.

Следует отметить, что исследования в области наркологии, в том числе и с использованием одурманивающих и вызывающих оцепенение ядовитых веществ, известны едва ли не более тысячи лет. Наркология же как наука с ее практическими приложениями в современном понимании ее содержания и значения насчитывает лишь около двух столетий $[15,152,153,192,311]$. В то же время, на что следует обратить внимание, появились обоснования особой категории цивилизации, именуемой наркоцивилизацией [21].

К числу формулированных выше актуальных проблем наркологии следует присовокупить проблему анализа и оценки предпосылок первичного, вторичного и возможных последующих причин возникновения и условий сохранения наркомании вне зависимости от пола, возраста, национальности, вероисповедания (от того, принадлежит ли наркоман к православию, католичеству, протестантству, иудаизму, исламу, буддизму или иным религиозным верованиям); проблему ландшафтных отличий и экологических условий мест пребывания наркомана, от его перемещений в пределах одного или нескольких государств, от характеристик его личной и семейной жизни, от качества, уровня, условий, стиля и уклада жизни, от числа старших и младших членов семьи и их взаимных отношений, от супружества и замужества, от числа и личных качеств сотрудников, условий деятельности коллектива, от условий проживания семьи или без семьи - в отдельной комнате, квартире, в собственном доме, от личного финансового благополучия и финансового благополучия семьи и родственников, от состояния здоровья и сущности заболеваний, от инвалидности или перехода на пенсионное обеспечение.

\section{Сущность зависимости}

Как известно, у наркоманов и токсикоманов возникает зависимость от наркотиков, психотропных и токсических веществ, вызывающая необходимость получения ответа на многие вопросы. Существенны знания того, в чем заключается биологическая сущность наркотической и иной зависимости, по каким причинам, после какого срока и на основании каких механизмов при возникшей зависимости появляется абстинентный синдром - стремление не употреблять 
зелья, и возможно ли ускорение появления последнего, естественно, с учетом того, какие зелья потреблялись [136, 137, 166]. Оправдано привести определение терминов, принятых экспертами ВО3 [136]:

- лекарственная зависимость - «состояние психики, а иногда также физическое состояние, возникающие в результате взаимодействия организма и лекарственного средства, характеризующиеся определенными поведенческими и другими реакциями, которые всегда включают настоятельную потребность в постоянном или периодически возобновляемом приеме определенного лекарственного средства для того, чтобы испытать его действие на психику, а иногда для того, чтобы избежать неприятных симптомов, обусловленных прекращением приема этого средства. Индивидуум может страдать зависимостью более чем от одного лекарственного средства»;

- психическая зависимость - «состояние, при котором лекарственное средство вызывает чувство удовлетворения и психического подъема и которое требует периодически возобновляемого или постоянного введения лекарственного средства для того, чтобы испытать удовольствие или избежать дискомфорта»;

- физическая зависимость - «адаптивное состояние, которое проявляется в интенсивных физических расстройствах, когда прекращается введение соответствующего лекарственного средства. Эти расстройства, то есть синдром абстиненции, представляют собой комплекс специфических симптомов и признаков психического и физического свойства, которые характерны для каждого вида наркотика»;

- вызывающее зависимость средство - «средство, обладающее способностью при взаимодействии с организмом вызывать состояние психической или физической (или той или другой зависимости одновременно). Такое средство может быть применено по медицинским показаниям или без таковых, не обязательно вызывая состояние зависимости. Особенности состояния лекарственной зависимости, если оно уже развилось, варьирует от вида применяемого средства. Некоторые виды наркотических средств, включая те, которые присутствуют в чае или кофе, обладают способностью вызывать зависимость в самом широком смысле слова. Наличие такого состояния не обязательно является вредным само по себе. Однако принято считать, что некоторые виды наркотических средств ввиду их способности вызывать значительную стимуляцию или депрессию центральной нервной системы или расстройство восприятия, настроения, мышления, поведения или двигательной функции при определенных условиях их употребления, могут создавать проблемы для индивидуума, общества или общественного здравоохранения, или социальные проблемы» $[232,233]$.

Вызывают зависимость вещества:

1) алкогольно-барбитуратного типа - например, этиловый спирт, барбитураты и некоторые другие средства, обладающие седативным действием, такие, например, как хлоргидрат, хролдиазепоксид, диазепам, мепробамат и метаквалон;

2) типа амфетамина, например, собственно амфетамин, дексамфетамин, метамфетамин, метилфенидат и фенметразин;

3) типа каннабиса - препараты из Cannabis sativa L., такие как марихуана (бханг, дагга, киф, маконха), ганжа и гашиш (чарас);
4) типа кокаина - кокаин и листья коки;

6) типа кхат (хат, чат) - препараты Catha edulis Forssk;

5) галюциногенного типа, например, лизергид (ЛСД), мескалин и псилоцибин;

7) типа опиатов (морфина), например, морфин, героин, кодеин и синтетические аналоги морфина - метадон и петидин;

8) типа эфирных растворителей, например, толуол, ацетон, тетрахлорметан.

Важны ответы и на следующие вопросы.

1. Каковы биохимические и физиологические механизмы зависимости от курения табака и махорки? Хотя табак и махорка не включены в приведенный выше список, они, несомненно, являются веществами, вызывающими зависимость и способными наносить ущерб здоровью курящего. Курение же настолько широко распространено, что представляет серьезную проблему для общественного здравоохранения. Табак и махорка оказывают относительно небольшой стимулирующий или депрессивный эффект на центральную нервную систему. Вместе с тем, вред, наносимый ими здоровью, велик.

2. Имеет ли место генетически и (или) эпигенетически обусловленная предрасположенность к наркомании и токсикомании, и в чем сущность механизмов такой предрасположенности [120, 311]?

3. Каковы причины отчуждения младших членов семьи от старших членов семьи вне зависимости от того, кто из них и когда стал наркоманом, и каковы личные последствия наркомании [19]?

4. Какова сущность закономерностей и законов невротических состояний, в том числе и старческого психоза, истерического невроза, истерических психопатий, включая и проявившиеся в сроки пресениума $[19,303] ?$

5. Какое влияние на плод человека, его антенатальное и постнатальное формирование и его формирование в детском и в подростковом возрастах и в сроки взросления оказывают наркомания и токсикомания родителей, имеющие место в критические периоды развития, когда организм наиболее уязвим, в связи с чем возможны тератогенез и возникновение любых структурных, функциональных и метаболических нарушений, проявляющихся в самом разном возрасте [242]?

6. Какое значение в личной судьбе наркомана и токсикомана и в судьбе его родственников имело неосознание ими поразившей их патологической склонности - анозогнозия?

7. Каковы следствия обычного для лиц, испытывающих наркотическое одурманивание большей или меньшей навязчивости - диагностически известного в наркологической клинике как синдром навязчивого состояния, сопровождающегося навязчивыми аффектами, навязчивыми идеями, навязчивыми образами, навязчивой убежденностью в чем-либо, навязчивыми побуждениями к чему-либо, навязчивыми влечениями различного рода, то есть в целом в навязчивом поведении [139, 157, 200, 278, 323, 327]?

8. Какова действительная возможность обоснования, создания и использования в предупредительных, лечебных и воспитательных целях статистической и прогностической моделей наркомании и токсикомании, психических болезней в целом, установленных факторов риска, в первую очередь факторов риска неврозов и психозов $[130,256]$ ? 
9. В чем заключается сущность и значение для таких асоциальных явлений, как наркомания и токсикомания, темперамента, психической конституции и физического телосложения подверженных им лиц флегматиков, холериков, сангвиников, невропатической и психопатической конституции, конституции астеноидной, пикноидной, грацилоидной, атлетоидной - атлетической $[147,154,234,321]$ ?

10. Каково значение для конкретных психических больных, для родственных им лиц и для общества в целом этикетирования (стигматизации), соответствующего поставленному клиницистом диагнозу (его своего рода этикетка) - диагноза невроза, шизофрении и т. п., которые безусловно имеют социальный и психологический смысл и существенны как свидетельство эпидемиологии психических заболеваний $[122,231]$ ?

Весьма важны анализ и оценка взаимной зависимости психических аномалий и преступности, связанных, в частности, с невменяемостью-следствием алкоголизма [9].

Самостоятельный вопрос: в какой мере могут иметь значение модели проявления наркотизма, в частности, вызванного опиатами, каннабиноидами и иными веществами растительного происхождения, возникающие у домашних животных, в особенности жвачных [60]?

Изложенным не исчерпываются вопросы, на которые должны получить соответствующий ответ наркологи, криминалисты, врачи, социологи, юристы, священнослужители, посвятившие свою деятельность православию и вместе с тем ограничению и предотвращению распространения наркомании и токсикомании, потребления психотропных зелий и ликвидации последствий их потребления для больных и для их близких [31, 248-251].

\section{Исследовательские и практически задачи, причина которых - возникновение зависимости}

Изложенное свидетельствует, что наркомания и алкоголизм (в том числе детей и подростков) - биосоциальное расстройство, и социальная реабилитация лиц с таким расстройством должна иметь в основе семейную психотерапию, включающую в себя и психотерапию взрослых членов семьи [54].

Ответы на вопросы с упомянутым содержанием существенны для представителей любых конфессий, осознающих, какую опасность для России представляет рассматриваемое международное зло. В частности, весьма важно понимание того, что наркоманы - притягательные личности, привлекающие к себе воров, хулиганов, бандитов, нарушителей юридических норм в целом. Необходимо осознавать, что в настоящее время международная сеть Интернет приобрела значение своего рода справочной системы, дающей любому лицу возможность получить конкретные сведения о том, каким образом возможно изготовить наркотическое средство (гашиш, опиум, дезаморфин и т. д.) самостоятельно. Показательна историческая оценка менталитета многих этносов, для представителей которых потребление наркотических средств, например, потребление насвая, потребление кактуса Lophohora williamsii Y.M. Coult., коки (Cola spp. и Erythroxylum coca Lam.), ката (Catha edulis Forssk ex End1.), ибоги (Tabora iboga Baill.), священ- ного мексиканского гриба [Psilocybe cubensis (Earle Singer) и Psilocybe Mexicana Heim.], жевание листьев бетеля (Piper betle L.) - непременный атрибут повседневной жизни [12, 230, 264, 267, 295, 313].

Все более осознается необходимость диспансеризации подозреваемых на потребление наркотиков - школьников, студентов, взрослых. Становится безусловным, что лечение наркоманов требует использования соответствующих антидотов и чрезвычайно актуальна проверка их избирательного эффекта и правил применения [86, 202, 203, 284, 298]. При установлении путей наркотрафика оправдано использовать как целенаправленно обученных собак, так и специализированные одориметры - измерители запаха, создание и апробация которых - актуальная российская и международная проблема.

Так называемый наркоманами «кайф» - удовольствие, испытываемое наркоманами при потреблении (инъекциях) наркотика, - основание их заболевания и сопровождающего возникшее заболевание неадекватного поведения (включая и саморазрушающее поведение подростков), описываемого Зигмундом Фрейдом в сочинении «По ту сторону удовольствия» $[129,138,300]$. З. Фрейд отмечал, что «принцип удовольствия остается еще долгое время господствовать в сфере трудно “воспитываемых" сексуальных влечений, и часто бывает так, что он в сфере этих влечений, или же в самом Я, берет верх над принципом реальности даже во вред самому организму» [300, с. 383].

Оказалось, что потребление наркотика кокаина соответствует по последовательности изменений трем фазам реакции организма на возрастающий стимул, выявленным П.В. Симоновым, и проявлениям экспериментально установленного закона АрндтаШульца [264].

В связи с таким всесветным злом, как наркотические и психотропные средства, в особенности при чрезмерном употреблении и злоупотреблении ими, более чем своевременна и насущна одна из актуальнейших проблем современности - создание заменителей - имитаторов наркотиков, вызывающих упомянутый «кайф», наркомиметиков, психомиметиков в целом [8, 119, 144, 186, 299]. Очевидно, что разработка и создание и практическая апробация миметиков наркотических и психотропных средств мало реальна, если не невозможна без соответствующего специального моделирования вызываемого ими действия, по сравнению с тем, как это имеет место, в частности, при моделировании психики $[45,48]$. При моделировании психики, психической деятельности и отклонений и нарушений фактических и возможных, возникающих при этой деятельности, в том числе и возникающих при потреблении наркотических и психотропных препаративных средств (и их химических предшественников), непременно следует учитывать и стадии возникшей и возникающей зависимости, фактор времени в восприятии человека, время реакции человека, диагносцированная последовательность которых начинается со стадии адаптации к возникающему зелью, при его частом потреблении переходит в стадию хроническую, то есть возникшей зависимости и, далее, в стадию истощения (слабоумия и т. д.) - гашишизма, что может завершиться и часто завершается летальным исходом $[15,16,42,293]$. 
Потребление наркотических и психотропных средств приводит с понятной очевидностью к необходимости всестороннего исследования проницаемости, а также и проводимости для этих средств как структур сосудистой системы - систем макроциркуляции и микроциркуляции, так и структур макролимфатической и микролимфатической систем (естественно, и лимфатических сосудов и лимфатических узлов), причем с непременным учетом в аспекте проницаемости сосудов при внеорганном транспорте лимфы и гематолимфатических взаимоотношений $[148,149,215,238,310]$.

При исследовании проницаемости и проводимости наркотических и психотропных веществ необходимо учитывать и их потребление ингаляционным способом, с использованием которого возможно и поглощение барбитуратов [7].

Опасность наркотизма для всех стран и всех континентов столь серьезна, что важно анализировать любые пути его возникновения [252]. В связи с этим вполне оправдано внимание как к наркотическим и психотропным веществам эфирных масел, синтезируемых и продуцируемых растениями - представителями десятков семейств, сотен родов и многих сотен видов папоротникообразных, высших растений и грибов, принадлежащих флоре России, флоре Европы, флорам Азии, Африки, Австралии, флорам островов всех океанов и, соответственно, и к их микобиотам [75, 76, 91, 235, 281]. По данным М.И. Горяева, в 1952 г. в флоре СССР были известны 1054 вида эфироносных растений. Следует отметить, что изучение эфироносов осуществляется активно во всем мире. В СССР в Абхазии было создано одно из крупнейших в мире научно-производственных учреждений по интродукции, акклиматизации и всестороннему исследованию как отечественных эфироносов, так и эфироносов, произрастающих во многих иных странах. Объекты Сухумской опытной станции эфиромасличных культур - субтропические и тропические эфироносные растения - герань, пачули, евгенольный базилик, ветиверия, жасмин крупноцветный, эфиромасличная роза, лимонный эвкалипт, камфарный лавр, гардения, азалии, приморская лилия, бергамот, бигарадия, абельмош и многие другие, причем каждый эфиронос представлен различными подвидами и внутривидовыми культиварами.

Предшественник Сухумской опытной станции эфиромасличных культур в поселке Келасури - так называемый Военно-ботанический сад, созданный в Сухуми начальником Черноморской укрепленной береговой линии Н.Н. Раевским, указавшим на возможность выращивания в этом саду апельсинового, кофейного и камфорного деревьев, палиссандры, рожкового дерева (Ceratonia silique L.), бергамота и многих иных растений, сохранившихся и в двадцатом веке [70].

Душистые вещества химически весьма разнообразны и представлены соединениями многих классов [46]. Их пример: углеводороды: ациклические терпеновые - мерцен, ацимен, аллоцимен; моноциклические - лимонен, дипентен; бициклические $\alpha$-пинен, $\beta$-пинен, $\delta$-пинен, камфен, пипены; спирты: алифатические - этиловый, изоамиловый, нониловый и т. д.; ациклические терпеновые - гераниол, цитронеллол и т. д.; моноциклические терпеновые - терпенеол, ментол, виктол; ароматические - коричный, бен- зиловый, $\beta$-фенилэтиловый; простые эфиры - анизол, гваякол, эвгенол, жасмин-9, амброксид и т. д.; сложные эфиры карбоновых кислот - цитронеллилформиат, $\beta$-фенилформиат, линолилацетат, бергамилат, ветиверилацетат, стиралилацетат, этилвалериановокароновый эфир, метилбензоат, метилциннамат; эфиры антраниловой и фталевой кислот и т. д.; лактоны, альлегиды, апетали, кетоны, соединения с запахом мускуса, макроциклические диэфиры, индольные душистые вещества, душистые вещества из терпенилфенолов и т. д.

Значительный вред жителям России наносит алкоголизм, одурманивание, сопоставимое с эффектом воздействия наркотиков. Алкоголизм, в особенности затяжной, приводящий к так называемой белой горячке, к возникновению корсаковского синдрома, во многих случаях имеет следствием начало потребления наркотиков - опиофагию, кокаинизм, морфинизм, а при легком заболевании - кофеманию. Итог реактивные психозы с фугиформными реакциями, психогенным ступором, с помутневшим сумеречным сознанием и т. д. Упомянутые нарушения, как и нарушения при потреблении наркотиков и психотропных средств, имеют в результате чрезвычайно обширный и показательный комплекс возникающих отклонений, составляющие этого комплекса $[17,68$, $83,110,145,154,160,173,201,272,275]$ - нарушение понимания вопросов и ответов на вопросы, неадекватность ответов на вопросы и объяснений этих ответов, непонимание поставленных задач и их последовательности, нарушение смыслообразования и опосредованной памяти, непонимание читаемого текста, предметных образов, нарушение образной, так называемой иконической памяти, неспособность к наглядному и образному мышлению, медленность смены идей, скачки идей и возникновение нелепых идей, нарушение воли и волеизьявления, инертность, раздражительность, озлобленность и жестокость по отношению к людям и животным, агрессивность в целом, нарушение отношений с окружающими, насилие по отношению к близким в семье, к коллегам, к обществу, к государству в целом, неудачливость в личной жизни и деятельности, несосредоточенность, не оправданные и необъяснимые метания и, в связи с этим, возникновение и приобретение способности к аферам, нарушение самообладания, нарушение когнитивной способности, нарушение в оценке ценностей и обычных в бытовой жизни и в трудовой деятельности неопределенностей, неспособность к пониманию и принятию многошаговых последовательных решений, манипулятивное поведение, возникновение и проявление пассивно оборонительного рефлекса, неспособность к обучению общему и профессиональному и к переобучению, половые извращения и способность к промискуитету, ретардация и акцелерация у детей и подростков физического и умственного развития, возникновение металкогольных психозов (в том числе таких как галлюцинозы), делирий - помрачнение сознания с нарушением ориентации в пространстве и во времени, онейроид - помрачнение сознания с сновидениями и ориентационными и зрительными галлюцинациями, амения - помрачнение сознания с проявлениями растерянности, бессвязностью мышления, отсутствием памяти, двигательной возбужденностью, аутизм, нарушение краткосрочной, долгосрочной и так называемой аффективной памяти (памяти об 
эмоциональных переживаниях), шизофрения, эпилептические припадки [320]. Общий итог изложенного - оскудение и падение интеллекта и естественный летальный исход при чрезмерности потребления наркотиков, при чрезмерном алкоголизме, возникновение стремления к суициду. По существу суицид (при множественности его случаев, а такая множественность возможна при распространении как наркотизма и психотропных средств, так и при распространении алкоголизма) вполне реально оценивать как крайнее проявление геноцида по отношению к народонаселению Российского государства [88, 90, 124, 159, 293, 331-333].

Известный писатель Поль де Крюи устами героя своей книги «Борьба с безумием» Джека Фергюсона подчеркнул, что «психические болезни - химический сдвиг, поддающийся излечению (с. 13), «Безумие - это химическая проблема» (с. 29) и поставил вопрос о том (c. 27), «сколько форм у шизофрении?» (с. 89). С упомянутыми утверждениями и с содержанием формулированного вопроса нельзя не согласиться. Проблема продолжает анализироваться и в начале третьего тысячелетия, что свидетельствует о ее сохраняющейся актуальности. Алкоголизм - безусловная угроза государственной безопасности $[11,187]$.

Изложенное - свидетельство важности обеспечения своевременного начала лечения наркоманов (в том числе и лечения принудительного, донозологического, преморбидного) [188, 255]. В особенности донозологический диагноз существен, если пристрастие к наркотикам велико, в связи с чем есть достаточные и серьезные основания предполагать возникновение и внутриутробных следствия для ожидаемого ребенка [229].

Целесообразно учитывать химические взаимоотношения как наркотиков и психотропных средств, так и лекарственных препаратов друг с другом; тот факт, что наркотизм, как и алкоголизм, приводит к нейрохимическим следствиям, что имеют место пограничные психические расстройства, и достаточно часто депрессия завершается иллюзиями и галлюцинациями различного рода и, в итоге, приводит к агрессии, обращаемой к родственникам, к совершенно посторонним лицам, к животным [3, 20, 23, 50, $90,225,236,244]$. Алкоголизм - обычный источник преступлений против личности [155]. Уместно отметить [144], что при химическом наркозе, вызванном тиопенталом, закисью азота, сернокислой магнезией, хлоралгидратом, эфиром, смесью эфира и хлороформа, морфием и т. д., изменяется содержание в крови сахара, гликогена, лактата, пирувата, активность ферментов - участников углеводного обмена в головном мозге и в печени, окислительное фосфорилирование, обмен аденозинтрифосфорной кислоты, азотистый обмен, обмен белков, свободных аминокислот и аммиака в нервной ткани и т. д.

\section{Никотиномания, ее выявление и причины опасности}

Не уменьшается, несмотря на административные запреты и агитационные меры, распространение в России количества курящих, причем как взрослых мужчин и женщин, так и учащихся школьного и подросткового возрастов. Важно отметить, что курят не только папиросы и сигареты (собственно табак - Nicotiana tabacum L.), но также и махорку (Nicotiana rustica
L.). Опасность, и достаточно серьезную, для здоровья как курящих, так и некурящих, представляет имеющая место постоянно и повсеместно подверженность воздействию так называемого пассивного курения - вдыхание продуктов сгорания - табачного и махорочного дыма, распространяющегося от курящих лиц, находящихся вблизи от некурящих. Уместно отметить, что табакокурение, махоркокурение и пассивное курение факторы онкологического риска $(33,175,239,307)$.

Первостепенная по значению социальная и медицинская проблема - проблема табакокурения, никотиномании у детей и подростков. Важно распространение доказательных свидетельств об этиопатогенетических следствиях никотиномании для здоровья курящих, в особенности проявляющихся в нарушениях нервной системы, органов гемодинамики и репродуктивной сферы. Особое значение имеет оценка связи распространения курения с характеристиками жизни - образом, условиями, уровнем, укладом, стилем и качеством жизни. Важно выяснение зависимости никотиномании от взаимоотношений младших и старших членов семьи. Естественна необходимость сведений о никотиновой зависимости и обусловленной ею утомляемости.

Необходимо привлечь внимание и к актуальности прекращения потребления так называемого бездымного табака - причины рака рта и инициатора возникновения зависимости, способной вызвать летальный эффект [44].

В табачном дыме выявлены восемьдесят девять индивидуальных органических химических соединений, имеющих патогенетическое и гигиеническое значение [94].

Непременно следует отметить, что в отторжении от наркомании, потреблении психотропных зелий, алкоголизма и токсикомании, в лечении наркоманов, алкоголиков, противоправных личностей в целом и их социализацией - возвращением в нормальное общество активно и деятельно занимались и занимаются в настоящее время православные священнослужители. Их примеры - православный священник иерей Сергей Николаевич Слепян (отец Сергий) в девятнадцатом веке [249-252] и православный священник протоиерей Сергей Николаевич Бельков (отец Сергий Бельков) в настоящее время [31]. Православный священник Сергий Слепян был активным проповедником и являлся настоятелем построенной для него и по его плану церкви, находящей в Санкт-Петербурге по адресу: улица Боровая, дом пятьдесят два. Учитывая распространение наркомании, алкоголизма, пристрастия к табаку (курению) и у верующих, оправдано привести полностью содержание некоторых неоднократно изданных проповедей С.Н. Слепяна, сохранивших свое нравственное воспитательное значение и в настоящее время.

\section{«0 ПЬЯНСТВъ»}

(1886 г.)

«Пробудитесь, пьяницы, плачьте и рыдайте вси пьющіе вино» (Іоиль 1,5). «Прилично-ли и благовременно-ли бесьдовать нынь о томь предметь, который я избралъ для своей бесьды? могуть возразить нькоторые, хотя слова, берущія свое начало изъ Священнаго Писанія, всегда прилично и 
благовременно произносить в обществђ христіанъ, ибо апостоль говоритъ: «Проповьдуй слово, настрой во время и не во время» (2 Тим. 4.2). Но, христіане, прислушивайтесь къ постоянному гласу Церкви, и тогда вы убђдитесь, что всегда прилично говорить о трезвости. Святая церковь, совершая память святителей, взывает сльдующее: «воздержаніе учителя явится стаду твоему, яже вещей истина».

Итакъ, мы слышали, что святители, память которыхъ мы чтим, въ жизни своей были учителями воздержанія, так же какъ истинное христіанское благочестіе безъ воздержанія немыслемо. Теперь спрошу васъ, достояноли чтить святителей русскій народъ, когда, забывая свое христіанское званіе, онъ предается пьянству и проистекающему отсюда сквернословію и богохульству? Внимаеть-ли онъ постоянному гласу Церкви, призывающему всьхъ къ воздержанию? То широкое развитіе, которое получило на Руси пьянство, свидьтельствует, что голосъ Церкви въ этомъ отношеніи остается гласомъ вопіющимъ въ пустынь, ибо почти половина русскаго христіанского народа предается этому пагубному пороку. Въ этомъ невниманіи къ голосу Церкви и кроется главная причина широкаго развитія пьянства. Но тогда какъ одни предаются этому пагубному пороку всльдствіе невнимательного отношенія къ христианскому ученію, другіе оправдывают себя тьмъ, что будто-бь употребленіе вина дозволено Священнымъ Писаніемъ. Въ такомъ случађ указываютъ на слова апостола Павла, обращенныя къ своему ученику Тимофею: «впредь не пей одной воды, но немного вина ради желудка твоего и частыхъ недуговъ твоихъ» (Тим. 5.2.3). Но изъ этихъ словъ не видно, чтобы апостоль Павель поощряль винопитіе. Онъ прописалъ вино Тимофею, какъ лекарство противъ бользни, которой подверженъ былъ Тимофей; и онъ не могъ имьть въ виду современное пристрастіе къ вину; а потому сильно оскорбляетъ апостола всякій, предающійся вину и, Тьм болье, оправдывающійся словами-же апостола, смыслъ которыхъ онъ не понимает, или не хочет понять. Образумься, христіане! Вспомни, чьимъ словамъ ты даешь превратный смысль, говоря, что апостоль не запретиль пить вино! Апостолы или посланники Того, Который пришелъ взыскать и спасти погибшее, могли-ли терпьть въ своихъ посльдователяхъ, когда всьмъ извеђстно, что вино бываеть началомъ гнуснаго поступка и причиною зла, беспорядочности въ обществђ, ослабленіем силь государства, несчастіемъ семействъ и всякаго отдђльнаго человька.

Теперь, укажемъ на ть посльдствия, какія происходять оть пьянства. Посльдствія эти настолько печальны и ужасны, что невольно сердце содрагается при одномъ лишь размышленіи о конць пьянства. Пьяница настолько унижаеть свое человьческое достоинство, что не заслуживаеть названія человђка; настолько унижаетъ въ себь христіанское званіе, что не вправь называть себя столь высокимъ именемъ. Богь далъ человьку великія преимущества дущи: умъ - к познанію истины, свободу воли, чтобы онъ не сльдовалъ сльпымъ влеченіямъ и наклонностямъ чувственности, но повиновался Закону Божію и исполняль его волю. Пьяницаже лишенъ этихъ преимуществъ, дьлающихъ насъ богоподобными. Онь пренебрегаеть ими и доходить всльдствіе невоздержимости до такого состоянія, гдь онъ теряетъ разумъ, сознаніе, гдь онъ не знаеть, что говорить и дьлает; гдђ, скажу болье, онъ оскорбляетъ и прогньвляетъ Бога своими грђхам болье, нежели всякій другой грђшникъ. Обыкновенный грђшникъ преступаеть одну какую-либо заповьдь Божію, пьяница же грБшить противъ всьхъ заповьдей Закона Божія. Преступаетъ онъ первую и вторую заповьди, ибо творитъ себь множество кумиров похотливое сердце его, не останавливаясь ни предъ чьмъ, лишь-бы угодить себь и діаволу. Третья заповьдь гласит: «не пріемли имени Господа Бога своего всуе» (Исх. 20.7), а пьяница за рюмку водки на кольняхъ божится хоть сотню разъ. Нечего говорить, что пьяница преступает и четвертую заповђдь. Онъ только и радъ субботнему дню, чтобы удовлетворить своей страсти, напивается до безпамятства и, вмћсто того, чтобы освятить этоть день, который долженъ быть посвященъ Господу Богу, онъ старается, какъ можно болье, послужить вђрно въ угоду діаволу, губителю душ нашихъ. Пятая и шестая заповьди гласять: «чти отца своего и матерь твою», «не убій», а пьяница нерьдко дьлается и убійцею родителей, да и готовъ всякому встрьчному безъ всякой причины голову разсьчь. Грьшить пьяница и противъ восьмой заповьди - «не укради», ибо онъ не останавливается предъ чужою собственностью, лишь бы утолить жажду водкою. Седьмая заповђдь - «не прелюбодђйствуй». Но начало блудодђянія и лежитъ именно въ пьянствђ, почему св. Апостолъ Павелъ и говоритъ - «не упивайтеся виномъ, въ немъ же есть блудъ» (Ефес. 5.16). Десятая заповьдь - «не лжесвидђтельствуй». Но предъ какою ложью у пьяницы можеть явиться мысль, что она ложь? Онъ сколько угодно будеть говорить ложь или дђлать лживыя показанія, въ особенности, если за эту ложь ему будет предложено вино. Десятая: «не пожелай себь жены ближняго твоего, не пожелай себь дома его»... Этою заповђдію запрещается не только дђлать вредъ ближнему, но даже желать ему чего-нибудь дурнаго. Пьяница же въ своемъ разгоряченномъ состояніи не останавливается ни предъ чьмъ и весьма часто наносить не только незначительный вредъ ближнему, но даже дьлается убійцею его. А если такъ, то не остается повода думать, чтобы пьяница оть всего сердца не пожелаль ближнему своему всякаго рода зла и несчастій. Воть таковъ конецъ пьянства. Оно ведеть къ полньйшему нарушенію всьхъ заповьдей Закона Божія. Ньть зла, котораго пьяница неспособенъ-бы сдьлать. Можетли такой человђк, рабъ постыднћйшей страсти, быть блаженным въ вђчности? НБтъ, «пьяницы царствія Божія не насльдятъ» (1 Кон. 6.10), потому что они служать не Богу, а діаволу, и не вправь такіе люди называть себя христіанами, потому что они покорнђйшия дђти діавола. «Вы отца вашего діавола есте и похоти отца вашего хощете творити» (Іоан. 5.44). Можно-ли назвать ту страну и 古 народы христіанскими, у которыхъ дни, установленные Самимъ Богомъ для тьлеснаго отдыха и освященія души, проводятся въ пьянствђ, противномъ Богу и всьмъ порядочнымь людямъ? Когда въ Ть дни, которые болье другихъ прилично провести въ Церкви, въ этомъ училищь благочестія, где благословеніе Божіе рђкою льется на вьрующихъ, или въ благочестивой 
бесьдђ въ кругу своего семейства, чего въ другіе дни не всякому возможно, Церковь на половину бываеть пустою, и эта половина, можно сказать, такъ задумывается о житейскомъ, что часто, не дожидаясь окончанія службы, спьшить выйти изъ храма Божія. Въ этомъ случађ религіозно-нравственное огрубленіе христіанскаго общества обнаруживается во всей силь. Такавые христіане вполнь позабыли, что вьдь Самъ Господь Бог, установляя день субботній или воскресный, повельвает святить его. «Помни день субботній, еже святите его», говоритъ Богъ (Исх. 20.8), и начало ему Самъ положиль: «и благословиль Бог день седьмый и освятиль его» (Быт. 2.2-3). Посль приведенныхъ словъ Священнаго Писанія, скажите - исповьдуеть-ли тоть апостольскую вьру, живеть-ли онъ согласно заповьдямъ Божіимъ, илиже преступаетъ ихъ въ ужасной мьрь, и заслуживаеть-ли онъ христіанскаго имени, кто, не дождавшись окончанія службы, спьшить выйти изъ храма, чтобы угодить діаволу и оскорбить Христа Бога и святыхъ угодниковъ, которые въ это время ходатайствують предъ престоломъ Всевышняго о ниспосланіи роду человьческому благодати и нужныхъ ему милостей. Да, въ то время, когда въ Церкви Христовой одни вьрующіе, изображающіе Херувимовъ и Серафимовъ, воспьвають Богу ангельскую пьснь, другіе, тоже называемые членами Церкви, крещеные во имя Отца и Сына и Святаго Духа, широко раскрывають двери воздвигаемыхъ ими храмовъ для восхваленія діавола и угожденія ему. Пьяница настолько вьрно служить діаволу, что забываеть даже христіанскій долгь исповьди, на которой онъ не бываеть по нБскольку льть. Правильно гворить апостолъ: «какое общеніе свьта съ тьмой, Христа съ Веліаромъ» (2 Кор. 6.14)? Къ чему пьяниць Богь и Церковь, когда они говорять противъ него? Пьяницамъ, если и нравятся установленные Богомъ праздничные дни, то потому лишь, что могуть усерднће служить діаволу. Посльдній-же радуется, когда христіанинъ начинаеть пить крБпкіе напитки, онъ знаеть, окаянный, что пьяница весь тогда принадлежить ему и въ сей жизни, и въ будущей.

Однако пьянство, лишая человька христіанскаго званія и насльдованія царства Божія, дьлаеть его негоднымъ не только для религіозно-нравственной жизни, но и для жизни общественной и государственной. Живя въ государствь, каждый гражданинъ несеть какой-либо трудъ, который служить на общую пользу государства, и поэтому каждый человьк является общественнымъ дБятелемъ. Всякій, призванный на военную службу, заботится о вньшнемъ благополучіи своего отечества, оберегаетъ государство оть нападенія вньшнихъ враговъ, стоить за вьру, Царя и отечество, словомъ, является общественнымъ дьятелемъ. Такимъ же общественнымъ дБятелемъ является и всякій, рБшившись работать на фабрикь, ибо онъ способствуеть матеріальному обеспеченію своего отечества. Но приносить-ли воинъ или человькъ, работающій на фабрикь, обществу и государству какую либо пользу, если онъ въ высшей степени преданъ пороку пьянства? НБть, не приносить, потому что пьяница безпеченъ и льнивъ къ труду, отличается неряшествомъ, пренебрегаеть своими занятіями и вносить въ общество одно лишь ослабленіе силъ. Итакъ, пьяница не можеть быть общественнымъ
дБятелемъ и только отягощаеть общество своимъ существованіем.

ДБлая человька непригоднымъ для общественной жизни, пьянство доводить его до того, что онъ бываеть несносенъ и для жизни семейной. Трудно предположить, чтобы пьяница могь быть вьрнымъ супругомъ, благопопечительнымъ отцом, чтобы онъ въ состояніи былъ дать своему семейству доброе воспитаніе и чтобы могь управлять своимъ домомъ. Каждый, кто въ сношеніи с нимъ, долженъ страдать оть его отвратительнаго характера и сварливости, долженъ терпьть грубости и оскорбленія. Мало того, семейство, Въ которомъ отец или мать преданы пороку пьянства, часто не имъетъ теплой комнаты, а обрьтаеть себь пріють въ темномъ углу, въ которомъ ему нерБдко приходится холодать и голодать, потому что родители всь зароботки свои несутъ въ питейныя заведенія, чтобы удовлетворить своей страсти и угостить знакомыхъ. Семейство же, оставленное на произволъ судьбы, перенося голодъ и холодъ, подвергается различнымъ бользнямъ и умираеть, не дождавшись медицинской помощи, а все почему? - потому что отець или мать пьяницы; деньги имъ нужно пропить, а не позвать доктора и подать больному помощь вовремя.

Для болье нагляднаго представленія того зла, которое пьянство вносить въ семейную жизнь, разскажу вамъ факть, котораго я былъ очевидцемъ.

Наканунь одного праздника, поздно вечеромъ, охая и ломая руки спьшитъ женщина, плохо одьтая на видъ, изнуреннаяи убитаягоремъ. Видъэтойженщины невольно остановилъ мое вниманіе, и я рБшился сльдовать за ней. Она поспьшно вошла въ ближайшій трактиръ, обошла всь комнаты и, не найдя нужнаго ей человька, поспьшно вышла. Я за ней, стараясь не быть ею замђченнымъ. Противъ этого же трактира былъ другой, куда она съ тою же поспьшностью завернула и, снова обойдя всь комнаты, хотьла уйти, какъ голосъ изъ билліардной остановиль ее вниманіе. Не блестящее освьщеніе, не веселые звуки органа и голоса пьсенниковъ влекли ее въ ту комнату; ньтъ! Она слишком много испытала, чтобы узнать, до какой печали, до какихъ тяжелыхъ посльдствій доводить это сборище. Она вошла въ ту комнату въ виду того, что услышала голосъ своего мужа, который передъ алтаремъ Божіимъ присягнулъ быть ея вьрнымъ соучастникомъ во всБхъ случаяхъ жизни, въ радости или печали. Она могла разсчитывать на него болье, чьмъ на кого-либо, ТБмъ болье, что этоть человькъ есть главный виновникъ ея страданій и безконечныхъ слезъ, и отецъ ея дБтей - этихъ невинныхъ страдальцевъ и мученниковъ. Она увьщевала его идти, но онъ не шелъ и угощалъ себя и другихъ своихъ пріятелей, такихъ-же безсердечныхъ людей. Горе заставило эту женщину повторить свое увьщеваніе, а этоть сильный и тучный мужъ, силою легіона бБсовъ, въ немъ обитающихъ, толкнулъ разстроенную здоровьемъ жену свою, и она, ни слова не говоря о только что совершенномъ поступкь, едва слышнымъ голосомъ сказала: «Андрей, сжалься надо мною хоть на этотъ разъ, дай мнь сорокъ копьекъ, и я үйду. Я ждала тебя весь вечеръ съ жалованьемъ, твой обьдъ простылъ, и Маша также хотьла тебя видьть, но ты не пришелъ, хотя раньше и обьщаль возвратиться». 
«Ничего не дамъ, ступай вонъ, развђ женское дьло по трактирамъ шляться».

«Андрей, - повторяеть она, - мнђ для себя ничего не нужно; но дай мнђ сорокъ копьекъ для Маши на лекарство, еще съ утра думскій докторъ прописалъ и вельль скорђе ей давать».

«Не уйдеть вьдь, скажите на милость», - обращается мужъ къ своимъ сообщникамъ, которые усердно поддерживаютъ авторитеть и право мужа надъ женою, кивая головами.

«Андрей, - повторяетъ она, но уже съ великимъ усилиемъ, - ты больше Маши не увидишь, докторъ сказалъ, что она умретъ».

И женщина ушла, заливаясь горючими слезами.

Воть въ какомъ аду живеть женщина, мужъ которой пьяница! Ей легче-бы лежать трупомъ въ могиль, чьмъ жить съ такимъ мүжемъ и видђть, какъ всльдствіе безпечнаго отношенія его къ своему семейству онъ допускаеть умереть быть можеть единственное ея дちтище. Только что разсказанный факть повторяется очень часто, и грђшно, и непростительно христіанскому обществу допускать, чтобы они повторялись. ВБдь даже животное по инстинкту заботится о своихъ дьтенышахъ, питаеть и грьеть ихъ, а человькъ, созданный по образу и подобію Божію, извращаеть всякое понятіе о своемъ семействђ, заставляеть его нерьдко холодать и голодать, подвергая этихъ невинныхъ страдальцевъ различнымъ бользнямъ.

Воть какъ гибельно дЂйствует пьянство на семейное благополучіе. Оно вполнь разстраиваеть семейный союзъ и пускаетъ терпьть семейство постоянную нужду в чемъ-нибудь. Но еще ужаснђе представятся намъ посльдствія пьянства, если мы примемъ во вниманіе, что такая жизнь родителей совершается на глазахъ молодаго покольнія, которое въ скоромъ времени должно начать свою самостоятельную семейную жизнь. Оно, какъ уже видЂвшее, что родители его постоянно пьянствовали, бушевали и производили различнаго рода безобразія, само начинаеть жить такою-же жизнію. И воть цьлыя покольнія растутъ въ такомъ пагубномъ направленіи. Неудивительно поэтому, что столбцы газеть переполнены извьстіями, повђствующими намъ о томъ или другомъ проступкь на поприщь государственной и общественной дьятельности. Неудивительно, что тюрьмы переполнены заключенными, а мћста на скамьђ подсудимыхъ занимаеть и старъ и младъ, и женщины, и даже дьти. И горе современному христіанскому обществу; ему приходится строить тюрьмы даже для малольтнихъ преступниковъ! Откуда это зло? Изсльдуйте причины, и вы найдете ихъ именно въ винь. Отецъ или мать были пьяницами и своимъ безобразнымъ поведеніемъ и безнравственными поступками пріучали собственное семейство къ такому-же образу жизни. Вотъ причина столь печальнаго явленія.

Кстати разскажу вамъ, что я читаль въ одной газеть. Юноша, будучи заключенъ въ тюрьму за проступокъ и осужденъ въ каторгу, просилъ тюремнаго начальника дозволить ему сходить на могилу матери, которая умерла нちсколько льть тому назадъ. Конечно, начальство, видя въ просьбь юноши благое стремленіе, разрьшило отпустить его на могилу. Приблизясь къ ней и видя разстройство преступника, солдаты оставили его, а осужденный, взойдя на могилу, опустилъ голову и затьмъ такъ сильно удариль ногами о могилу матери, что цБпи брякнули.

Юноша-же залился слезами и раздирающимъ душу голосомъ проговорилъ: «Это ты, мать моя, довела меня до такого состоянія: ты пьянствовала и учила меня воровать, чтобы тебь было что носить въ кабакъ и пропить; теперь же я иду на пожизненныя страданія, но такъ будь проклята такая мать!» Да, грустны такія проявленія в обществђ! Это сотни могиль пьяницъ, которыя вырывають каждый годъ, будуть всегдашними памятниками нашего нерадьнія о спасеніи ближнихъ и лучшими свидьтелями грядущему покольнію.

Теперь позволь-же мнь, собрать и сонасльдникъ небеснаго царствія, обратиться къ тебь лично со словомъ. Ты, содержатель питейнаго дома, ты, членъ Церкви Христовой, носишь кресть какъ символь вьры, прощенія, умиротворенія съ Богомъ, чаянья воскресенія мертвыхъ и жизни будущаго вька, а между тьмъ ставишь преграды спасительным дђйствиямъ на земль Христа Бога твоего? Какое богохульство! Ты вьшаешь въ питейныхъ домахъ святыя иконы, зажигаешь предъ ними лампады! Это только доказываетъ сльпое состояніе вьры въ твоей душђ; и как несообразно, чтобы ты, занимающійся такимъ неблаговиднымъ промысломъ, занималъ обязанности попечителя въ различныхъ богоугодныхъ учрежденіяхъ, каковыя мћста ты себь какимъ-то путемъ завоевываешь. Обыкновенно говорять: «Смотрите, какіе благотворители!» Но куда намъ такихъ благотворителей; если они не будуть спаивать народъ, если пьянству не дадутъ такого простора, какимъ оно пользуется теперь, - тогда не нужно будеть намъ заботиться о пріисканіи средствъ на содержаніе столькихъ домовъ для умалишенныхъ, идиотовъ, сироть, вдовъ и безвременной дряхлости, ибо каждый отецъ семейства, будучи всегда трезвымъ, способен будеть трудиться и содержать какъ свое семейство, такъ и своихъ родныхъ и ближнихъ. Конечно, вы опасаетесь, что тогда не будеть мьста ничьмъ незаслуженныхъ почестямъ и титуламъ; но я вамъ скажу, что только тогда и будеть мьсто почестямъ и похваламъ, но истинно заслуженнымъ на поприщь общественной дьятельности, именно для народнаго образованія, религіознаго и нравственнаго просвђщенія и общественнаго благоустройства. Многимъ будетъ, конечно, трудно согласиться съ мыслію оставить такой промысель, который требуеть столь малаго труда и даеть столько прибыли. Діаволь обращаеть взорь кабатчика на его пяти и шести-этажные дома, на великольпную обстановку въ его квартирь, на звуки фортепіано, которые кажуться ему тьм слаще, что его дочь на немъ играетъ, на его положеніе въ обществђ, на его голосъ въ дђлахъ общественныхъ, тьмъ болье вспоминая, кちмъ и чБмъ онъ былъ, - и все это дала ему рюмка, которой онъ и жена его вьрно служили; но вспомнилъбы кабатчикъ-христіанинъ, во что она ему обходится? Какою цьною все это куплено и дома, выстроенные на эти деньги, справедливо назвать «акелъ дама» (мћесто крови), и будуть они свидђтельствовать противъ него въ день судный, а соучастнику такой благотворительной дђятельности Господь скажеть тогда: «Іуда! Цђлованіемъ- 
ли предаешь сына человьческого и Господа твоего» (Лук. 22.28). Къ такимъ благотворителямъ примьнимы грозныя слова Господа: «Невозможно служить двумъ господамъ, - сказал Спаситель, - не можете служить Богу и мамонь» (Матө. 6.24). Нельзя служить и участвовать въ дђлахъ Церкви Христовой, скажемъ оть себя, оставаясь внь ея. Одной рукой указать въ рай, а другою въ адъ, подать исцьленіе и отраву, заботиться о распространеніи свьта Христова и сьять мракъ, служить образцомъ благоразумія и благочестія и быть соблазномъ. Любезные слушатели, читатели, очень можеть быть, среди вась есть именно такіе, о которыхъ идеть рьчь, прошу васъ во имя Христа и Его страданій простить меня, если мои слова могуть огорчить васъ; это говоритъ вамъ друг, имћющій одну надежду съ вами на вђчную жизнь, не огорчайтесь и не отчаивайтесь, но вступите въ добрые воины Христовы, стряхните съ себя вьтхаго человђка со всьми дьяніями его и подымите сердце ваше горь, облекитесь въ новую одежду праведности и ризу всь ту Христова (Ефес. 4.24). Вспомните Матөія мытаря, Марію Магдалину у ног Іисусовыхъ, произнесите мытарскую молитву: «Боже милостивъ, буди мнь грђшному». Но не такъ, какъ произносите ее каждый день по привычкь, а произнесите ее съ искреннимъ сердечнымъ сокрушеніемъ проводить жизнь, согласную христіанскому идеалу. Разставаясь съ вашимъ промысломъ, не жальйте его, какъ не жальли своего промысла Андрей и Симонъ, сыновья Іонины. Спасайся какъ оть огня, ибо слова господа непреложны - «горе тому человьку, чрезъ котораго соблазнъ происходитъ» (Лук. 17.12). Поступая такимъ образомъ, не оглядывайся назадъ, а позабывъ прошедшее, стремись впередъ, подражая святымъ. И ты, создавшій свой содомъ, будучи рабомъ золотаго тельца, вспомни жену Лота и наказаніе за ослушаніе не оглядываться на оставленный ею противный Богу городъ Содомъ. Не сожальй о такихъ прибыляхъ, которыя даютъ тебь въ замћнъ вђчнаго блаженства вђчныя муки. Господь говорить: «ищите прежде царстія Божія и правды его, и все это приложится вамъ» (Матө. 6.33). Болье-же всего опасайтесь сьтей діавола, который слишкомъ лукавъ. Смотрите, какъ онъ всь обряды и установленія Церкви, которыя должны служить человьку ко спасенію души, успьль или старается завоевать себь. Въ дни ангеловъ, которые должны служить ничьм инымъ, какъ днемъ молитвы и служенія Богу, діаволъ велить созывать гостей, чтобы пировать и оскорблять Ангела Хранителя, да и часто гости бываютъ недовольны угощеніемъ и пріемомъ хозяина, когда не напились пьяными и не вернулись домой съ расшибленными головами и грязною душою. О дняхъ праздничныхъ нечего и говорить, такъ какъ всякій знаетъ, какъ проводятся эти дни. Поминовеніе усопшихъ установлено Церковью для молитвъ объ отпущеніи грьховъ усопшихъ, а православный христіанинъ не задумывается и предается въ эти дни разгулу и излишеству. Вообще всь душеспасительныя, благія установления Церкви, посредством пьянства, превращаются въ ньчто, не похожее на вьрующихъ въ истиннаго Бога, а скорье на сластолюбивыхъ язычниковъ, что и служитъ позоромъ для христіанъ. Православная цьрковь молить каждый день объ обращеніи невђрующихъ, но пьянство противорьчитъ этому и служить величайшею помђхою дЂлу распространенія христіанской вьры. Откуда у насъ христіанъ такое равнодушіе къ богослуженію, къ слову Божію, къ нуждающимся въ вашей помощи. Сколько горя, сколько слезъ, сколько страдальцевъ!

Почему такъ трудно христіанское общество увьрить, что всь эти страдальцы - наши братья, наши сестры, соучастники небеснаго царствія, и что они имьють право на наше сочувствіе, на нашу помощь словомъ и делом? Отвђть готовъ, какъ только посмотримъ, какъ большая часть христіанъ живеть и проводить дни праздниковъ. Въ будни некогда пьянствовать, такъ любовь и ревность к наживь, замьтьте, болье имьють силы удержать оть пьянства, чемъ обязанность христіанская и богоугожденіе. Одинъ молодой человькъ шелъ въ Церковь. Друг его, встрђтившись съ нимъ, сталъ говорить: Гриша, пойдемъ со мной, я иду за городъ, и мы весело проведемъ воскресный день. Ньть, отвьчалъ Гриша, я намьренъ сегодня идти в Церковь. О, Гриша! Говоритъ ему друг, въ церковь всегда можно идти и, такъ какъ день сегодня прекрасный, то пойдем со мной, и мы весело проведемъ время. Искушеніе было слишкомъ велико. Гриша не могь не согласиться. И такъ, они пошли за городъ и провели весь день въ пьянствь и разгуль, а вечеромъ отправились по жельзной дорогь домой и, выходя изъ вагона, Гриша упалъ подъ него и былъ раздавленъ. Лежа въ своей крови, онъ говорилъ другу своему: «Дьло плохое, ты виноватъ всему этому, ты соблазнилъ меня и отвлекъ оть Церкви. Теперь, я хочу, чтобы завтра ты сказаль нашим товарищамъ, что причиною настоящаго приключенія послужило пьянство и несоблюденіе Воскреснаго дня, и знай, Иванъ, что ты виновникъ всего этого». «Пробудитесь, пьяницы, плачьте и рыдайте всь пьющіе вино». И такъ, жаль, что всь благія намьренія отца отечества и честныхъ тружениковъ общества разбиваются объ этотъ камень преткновенія - пьянство. Что можно сдБлать съ народомъ пьянствующим? Какія реформы, какія улучшенія можно провести на поприщь государственного и общественного благосостоянія, когда народъ одержимъ дремотою и сльпотою? Да, теперь, именно теперь, не откладывая, мы должны встать, какъ одинъ человькъ, и всячески стараться ослабить эту заразу, этот недугь. Къ вамъ, отцы! къ вамъ, матери, обращаемся со словомъ увьщанія! Пробудите и пощадите юношество, не шутите вьчностію вашею и вашихъ дЂтей, остерегайтесь пьянства и пьяницъ, Бог посмьянъ не будеть. Въ другихъ государствахъ и въ Россіи самымъ лучшимъ средствомъ противъ этого зла служать общества трезвости. Такія общества очень желательно основать какъ можно больше и организовать какъ можно систематичнье. Въ этомъ дђль нужно обращаться за руководствомъ къ нашимъ просвђщеннымъ пастырямъ церкви нашей. Русь побьдила много враговъ, какъ внђшнихъ, такъ и внутреннихъ. И теперь, братья, выступимте христовымъ именемъ против діавола, и успьхъ и побьда обезпечены».

\section{БЕСЕДА «0 ТАБАКЕ»}

$$
\text { (1897 г.) }
$$

Признаюсь, не безъ страха и трепета начинаю я, братія, вести съ вами бесьду о табакь. 
Куреніе есть зло, вньдрившееся во всь слои общества и имьющее своими приверженцами сильныхъ и мудрыхъ міра сего и какъ прихоть и пристрастіе имеђть, конечно, свою неестественную силу, которая здраваго обсужденія не принимаетъ, такъ, напримьръ, Китайцы, Индђйцы, пристрастившись къ потреблению опіума, несмотря на явный вредъ его для здоровья, продолжают его выкуривать, зная, что человькъ, предающійся этой прихоти, умираетъ постепенно, каждый день, такъ что, по истеченіи нђкотораго времени, дђлается живымъ мертвецомъ. Несмотря же на это, онъ, лежа на одрь смерти, причиной которой было употребленіе опіума, все еще продолжает курить его и всасывать въ себя ядъ до последнего своего издыханія.

я долженъ васъ предупредить, что, говоря о табакокуреніи, ябуду касаться преимущественнотого, насколько оно вредно человђку-христіанину въ нравственномъ отношеніи. Всьмъ извьстно, что все нужное и полезное человьку передается ему или попечительными родителями, или наставниками; табако-куреніе же есть только одинъ произволъ, потому что ни одни родители, какъ бы худы они ни были, не пріучають своихъ дьтей къ куренію, зная не только его бесполезность, но и вредъ, ибо дђти начинаютъ курить сначала совершенно безсознательно и тайно, затьмъ мало-по-мало втягиваются такъ сильно, что ужъ оставить табакъ не могуть и, вступая въ самостоятельный возрасть, курять открыто, не отдавая себь никакого очета: полезно-ли или вредно это.

Теперь приступимъ къ болье подробному разъясненію начатой мною бесьды. Табако-куреніем человькъ произвольно лишаеть себя и другихъ драгоцьннаго здоровья и подвергаеть себя и другихъ опасностямъ и величайшимъ несчастіямъ; есть явное противленіе человька своему Богу и твари Своему Творцу и Создателю вселенной, есть для всьхъ христіанъ явное служеніе сатань, врагу нашего спасенія.

Человђкъ, не чуждый чувства справедливости, конечно, не станетъ спорить о томъ, что табакъ вреденъ для здоровья курящаго и нерьдко бываеть причиною весьма печальныхъ посльдствій и несчастій, какъ отдьльныхъ людей курящихъ, такъ и совмћстно живущихъ съ ними.

$\mathrm{Bъ}$ табакь содержится весьма ядовитое вещество никотинъ, и этоть ядъ, всасываясь въ организмъ человђка-курильщика, рано или поздно производить на него свое разрушающее дЂйствіе.

Куреніе табаку причиняетъ исхуданіе, ослабленіе силь и вызываеть обильное отдђленіе слюны, столь необходимой для пищеваренія. Оно производить сильное біеніе сердца, сердечные спазмы, нервное возмущеніе и ослабленіе зрьнія.

Табакъ наводитъ на человђка мрачное настроеніе и дБлаеть его эгоистомъ. Доктор Декенъ, серьезно изучившій вопросъ о табакь съ точки зрьния гигіены и вліянія табаку на здоровье человька, доказываеть самымъ очевиднымъ образомъ, что куреніе производить разстройство въ кровообращеніи, въ пищеварительныхъ органахъ, тупость умственныхъ способностей, но это еще не все, оно имьет еще одно худое качество, оть котораго все человьчество стенаеть, именно развиваеть склонность к пьянству. у табако-курильщика еще замьчено самостоятельное развитіе жабы, воспаленіе гортани, рака языка и губъ; у людей же слабаго сложенія - чахотки.

Д-ръ Фрейманъ (въ Риґь) на себь самомъ наблюдалъ весьма доказательно хроническое отравленіе табакомъ. Авторъ, никогда не злоупотреблявшій ни алкоголемъ, ни возбуждающими средствами, но постоянно выкуривавшій от 6 до 8 очень крьпкихъ и большихъ сигаръ, въ теченіе 6 льть страдаль следующими бользнями:

1) болью подъ ложечкою, тошнотою, а иногда (особенно по утрамъ) и позывомъ на рвоту; преимущественно своеобразнымъ отсутствіемъ аппетита, который появлялся только при насильственномъ употребленіи пищи, при пребываніи на чистомъ воздухь и посль сильной мышечной работы; 2) сосудодвигательнымъ насморкомъ съ краснотою и зудомъ въ кожь; 3) мрачнымъ настроеніемъ духа, безсонницей и различными судорожными припадками въ органахъ дыханія и кровообращенія, въ кишкахъ и въ мочевомъ пузырь. Посль 6-ти мьсячнаго полнаго воздержанія оть табаку всь бользненныя явленія постепенно и, наконецъ, совершенно исчезли и больше не возобновились. Во время упомянутаго 6-ти мьсячнаго воздержанія авторъ 2 раза позволиль себь выкурить по очень хорошей сигарь и оба раза появилось сердцебіеніе, одышка, кашель, тошнота, рђзкая слабость, бльдность кожи, холодный потъ и, наконец, рвота.

Изъ вышесказаннаго ясно видно, что курильщикъ прямо дЬйствуеть противъ того, что есть самое драгоцьнное для человька и что составляетъ одно изъ главныхъ условий его счастія и благосостоянія на земль, - здоровья. «Ты же, отецъ семейства, не извинителенъ посль этого, губить свое здоровье такъ нужное тебь для пропитанія своего семейства».

Извђстно, что привыкшій къ табаку, когда только перестаеть курить, когда ньть возможности это дьлать, но при первой возможности берется за зелье. Бываеть такъ, что руки грязны, или заняты работою, тогда просить онъ близко стоящаго подать еу въ ротъ папироску и, такимъ образомъ, насыщается эта неестественная алчба. Курильщику ни почемъ ни присутствіе старшихъ, которымъ таковое д屯йствіе бываеть весьма противно, ни Тьснота комнатъ, въ которой нерьдко живутъ дьти маленькія, ни другія условія, необходимыя для ихъ развитія, по скудости средствъ родителей, не могуть быть доставлены. По крайней мьрђ, свьжій воздухъ становится въ такихъ случаяхъ самымъ необходимымъ, но и туть курильщикъ налагаетъ свою святотатственною руку.

ВБдь воздухъ Божій и Бог его даеть чистымъ, освьжающимъ и исцьляющимъ, а ты, курильщикъ, какое право имьешь отнять его, и распоряжаться здоровьемъ другихъ, да еще маленькихъ невинныхъ дђтей, которыя могли бы вырости людьми болье полезными церкви и отечеству, чБмъ ты, прихотливый курильщикъ.

Позвольте представить вамъ и факть, очевиднђйшимъ образомъ доказывающій, какъ табако-курильщикъ, повинуясь своей прихоти, нерьдко поступаеть не то что несправедливо, но крайне безчеловьчно.

$\mathrm{Bъ}$ одно приходское братство передъ праздникомъ Рождества Христова поступила просьба одной престарьлой вдовы, находящейся въ весьма 
бользненномъ состояніи, объ оказаніи ей немедленной помощи. Прочитавъ эту просьбу, предсьдательствующій этого братства обратился съ сльдующими словами: «Братчики христіане, средства братства оскудђли, просящихъ много, но согласно этой просьбы я считаль необходимымъ предложить вамъ изсльдовать дђло этой вдовы, и если она окажется заслуживающимъ вниманія, то нужно будетъ оказать пособіе во что бы то ни стало, ибо положеніе этой вдовы, какъ описано въ просьбь, должно быть ужасное». На завтрашній день одинъ изъ братчиковъ отправился по адресу, чтобы узнать положеніе этой вдовы и въ какомъ размьрь требуется ей пособіе, и воть что представилось глазамъ его: на чердакь 5-ти этажнаго дома, въ маленькой комнать, на постель, полной лохмотьевъ, лежало исхудалое, похожее на трупъ тьло дряхлой старухи. На его привьтствіе: «Какъ здравствуть Анна Тимофьевна». - «Охъ, благодђтели, отвБтствуеть она, - гдђ туть до здоровья, воть Бог бы душу мою скорье взялъ-бы въ ту страну, гдь ньтъ воздыханій, ни печали». - «Зачђмъ отчаиваться, говорит надзиратель, - Богь милостивъ». - «Да, отвђчаетъ она, - Бог-то милостивъ, да люди нынче совсьмъ безъ милостей стали... На что родной мой сынъ и то»... Туть слова ея прервались, такъ какъ сынъ ея вошелъ съ трубкою во рту, молодой человђкъ, повидимому ремесленникъ. «Такъ вотъ что, Вася, ты мнь поскорђй дай лекарство, я мучаюсь удушьемъ, а докторъ вђдь говорить, что лекарство, имъ прописанное, должно сразу освободить меня оть этого». - «Лекарства еще ньтъ», - грубо отвђчалъ сынъ. «Какъ такъ ньтъ, родной мой, нешто ты не досталь?» - «Да вотъ за одђяло дали всего 55 коп., да за подушку 60 коп., а на остальныя купиль себь немного... табаку». - «Ах, Вася, родной мой, грьшно тебь такъ поступать, немного мнь осталось и жить-то, а ты еще болье сокращаешь ее... Истину тебь скажу, что дымъ отъ твоего куренія сокращаеть мою жизнь, а ты еще, при такомъ недостаткђ, тратишь посльднія крохи на этакую прихоть: грьшно, Вася, грьшно»...

Надзиратель, посланный оть братства, хотя и много въ своей жизни видаль горя у людей, но туть былъ такъ тронуть, что сейчасъ же вышель, чтобы, какъ можно скорье, помочь бБдной вдовь и, купивъ лекарство и необходимую провизію, принесъ ей и, преподавъ сыну нужное наставленіе, удалился. Такъ вотъ что дьлаеть пристрастіе къ табаку.

Господь Іисусъ Христосъ въ наставленіе всьмъ порицалъ дЊйствіе фарисеевъ тогдашняго времени, которые давали на храмъ Божій, но не давали нуждающимся родителямъ.

Темъ больше осужденія тебь, христьанинъ, что ты, лишая дряхлыхъ родителей нужной имъ помощи, не имьешь даже и того оправданія, что даешь на храмъ Божій для поддержанія его благольпія, но тратишь эти деньги на совершенно ненужное, и весьма вредное во многихъ отношеніяхъ зелье - табакъ. И сколько несчастныхъ случаевъ оть куренія табаку, сколько людей лишаются всего добытаго неусыпнымъ трудомъ? Сколько непріятностей, обидъ и лишеній готовъ переносить человькъ для того, чтобы пріобрьсти себь и дђтямъ кровъ и все необходимое для жизни?.. А прихотливый табачникъ туть налагаеть свою святотатственную руку, берется за трубку или папиросу, зажигаеть это зелье, чтобы всосать въ себя, спичку бросаеть, а тутъ и пожаръ, и многольтній трудъ иногда цьлыхъ смействъ предается уничтоженію; дряхлые старики, слабыя женщины и дђти оть испуга подвергаются увьчьямъ, лишаются ума, теряютъ зрьніе, такой великій даръ Божій, и остаются несчастными на всю жизнь. Иногда табачникъ долженъ употреблять всевозможныя хитрости, чтобы удовлетворить своей прихоти.

Иногда м屯сто, время или компанія не благопріятствуютъ тому, чтобы покурить, а покурить хочется; воть и пускается табачникъ на всякій обманъ, придумывает ложь, лишь бы покурить.

Лавка, наполненная москательными и легковоспламеняющимися товарами; кладовыя, полныя товара, упокованнаго бумагою и соломою; контора полна нудныхъ документовъ; но тутъ служащій курильщікъ тайно оть хозяина хочетъ покурить; а всльдствіе же какихъ либо обстоятельствъ уроняеть огонь, отчего происходить пожаръ; состояніе хозяина уничтожается, изъ богатаго хозяинъ нерђдко дђлается нищимъ, десятки служащихъ и ихъ семейства лишаются средствъ къ жизни, благодаря прихоти одного человђка.

Въ льтній прекрасный день пароходъ съ пассажирами уходитъ в море для пріятной прогулки; все, повидимому, благопріятствуеть тому, чтобы весело провести льтній день, наслаждаясь красотой природы, чтобы по ней узнать и уразумьть Всемогущество и Всемудрость ея Виновника Бога; ђздили часъ, два, все хорошо, всь веселы, наслажденіе полньйшее, пассажиры вполнь вознаграждены за подъятый имъ трудъ и спћшку для морскаго пути. Но тутъ на пароходь, вьдь, табачникъ-курильщикъ, ему во что бы то ни стало надо покурить, а то ему и радость не въ радость, и вотъ он закуриваеть папироску, курить и наслаждается, но, по привычкь, бросаеть окурокъ, который попадаетъ на близлежащій багажъ, откуда, по истеченіи ньсколькихъ минуть, показывается языкъ дыма. Пассажировъ, увид屯вшихъ клубы дыма съ огнемъ, обнимаеть страхъ и ужасъ; суматоха, паника общая, истерика, обморокъ. Плачъ женщинъ, крики стариковъ, жалобные голоса дБтей невинныхъ, вопіющихъ къ Богу о вразумленіи развращеннаго рода человьческаго, прихоть которыхъ увеличиваеть горе и страданія. Но, о ужас! надежда на спасеніе исчезла, смерть передъ глазами, глубокое море поглощаетъ безразлично старика и младенца, и вотъ дно морское дьлается могилою для ньсколько сотъ человькъ, нћсколько часовъ тому назадъ наслаждавшихся сладостями міра, сотни дђтей дђлаются безвременно сиротами, дряхлые старики выслушивают горькую вђсть о потерь своей утехи и подспорья попечительныхъ дђтей, плачъ и горе вселяются въ сердца друзей погибшихъ, а вина всему этому что? - необходимое условіе жизни, непредвидђнный случай? НБть - и ньть: прихоть, пристрастіе, народившееся оть глупаго подражанія.

Табако-куреніе, какъ и пьянство, оть частыхъ пріемовъ переходить въ страсть, становится необходимостью. Несмотря ни на какое время дня и ночи, если табачникъ не встрђтитъ препятствій, онъ непремђнно покурить, утромъ-ли, передъ обьдом, посль обьда и, пробудясь ночью, пьяница-курильщикъ ощупываеть мћсто, чтобы найтитабакちиспичкуипокурить. О, сколькобезпокойствъ, 
тревогъ, сколько вреда здоровью своимъ ближнимъ причиняеть куреніе? Наступиль поздній вечеръ, миръ успокаивается, труженики отдыхаютъ и сладокъ сонъ; дちти улеглись спать, благословенныя попечительными родителями: бользни и недуги, неминуемые спутники человђчества, на время оставляють в покођ свои жертвы и много сердецъ возносятъ за это время хвалы и благодарности Создавшему все премудростью Своею; но туть табако-курильщикъ, сообщникъ темнымъ силамъ, исконнымъ врагамъ человђческаго рода, выступаеть со своею ролью - разрушить созданное, разорить пріобрьтенное, отнять жизнь, данную Богомъ, сьять скорбь и производить слезы. Среди ночи крики... «Пожаръ! Горимъ! Спасите!» Испуганныя лица матерей умоляютъ о помощи съ оконъ съ грудными дьтьми на рукахъ, юноши и дЂвицы бросаются съ верхнихъ этажей, чтобы болье не увидьться съ жизнью, дряхлые старики и болящіе тьломъ задыхаются на ложахъ своихъ, напрасно умоляя о спасеніи. «Маменька! Папенька!» - кричать дьти съ колыбели, думая найти помощь, съ смежныхъ домовъ несутъ милосердіе Божіе, сокровище семейное.

$\mathrm{Bъ}$ теченіе нђсколькихъ часовъ десятки жизней погибають - всюду нищенство, опустошеніе. Конечно, причина (что это все произошло оть куренія) остается неизвђстною, курильщикъ избђгаетъ кары людской, но не избьгаеть онъ кары Божьей.

Право, я задумываюсь, не знаю, что и сказать еще o табако-куреніи женщинами. Развь оно недостойно порицанія? О, женщина, тебь дано самимъ Богомъ высокое назначеніе имьть такое громадное вліяніе какъ въ нравственномъ, такъ и въ физическомъ отношеніи на воспитаніе ребенка, - сдьлать изъ него человька, полезнаго обществу, угоднаго Богу, вьрнаго слугу Царю и отечеству, и это вліяніе никьмъ не оспаривалось, а наобороть, возвышало тебя въ глазахъ общества и тьмъ самымъ какъ бы опровергаешь усвоенное обществомъ высокое о тебь мньніе. Если мою брошюру будеть читать женщина, мать-христіанка, то я, конечно, могу предложить ей и увьщанія Ап. Петра (1 посл. 3 гл., 2 ст.), что женщина-христіанка должна соблюдать чистое и богобоязненное житіе, сльдовательно, и куреніе должно быть устраняемо, какъ противное сему завђщанію.

Куритель явный противникъ Богу, который, по премудрости Своей, сотворилъ человька и все нужное для его благосостоянія и счастія предоставилъ въ его власть и безпрепятственное пользованіе. Земля произрастаеть плоды и растенія, домашнія животныя дополняють питательный продукть человьку и служатъ необходимою помогою въ его трудахъ. Льса, звћри, вода, воздухъ, травы - все это, какъ необходимое, предоставлено въ пользованіе такъ, что царь-пророкъ, образцовый молитвенникъ и пьснопьвецъ, завђщаеть грядущимъ покольніямъ (Ис. 77,4): «Благослови Душе моя Господи» (пс. 103, 1), и изъ всего этого можно заключить, что все, дђйствительно необходимое въ жизни человьку, онъ ощущаетъ потребностью и, лишаясь которыхъ, существованіе его становится невозможнымъ. Табакъ-же никоимъ образомъ не можеть считаться необходимостью и непремьннымъ условіемъ жизни, такъ какъ куреніе только стало извьстно съ 1492 года, въ Европь къ нему стали привыкать лишь съ 1496 года, а у насъ и того еще позже: приняли же къ стыду нашему эту гибельную страсть просвђщенные христіанскою вьрою европейцы отъ дикихъ индђйцевъ-язычниковъ, сльдовательно, человьческій родъ существовалъ безъ всасыванія этого яда около 7000 льть, а потому и становится яснымъ, что куреніе и есть, какъ выражается профессоръ Догель въ своемъ публичномъ чтеніи о вредь табака, - прихоть и несчастіе человька.

Табако-курильщикъ выступаетъ явнымъ воздержателемъ Творцу Вселенной, находя, что свђжій воздух лишній для человђка, тогда какъ свђжій воздухъ настолько необходимъ ему, что люди обыкновенно за измђненіемъ свђжаго воздуха дђлаются бльдными, теряють аппетить, здоровье ихъ ухудшается, а медицина прибьгаеть къ свђжему воздуху какъ къ наилучшему средству для скорьйшаго изльченія своихъ паціентовъ, такъ какъ всьмъ извђстно, что въ льтнее время для болье удобнаго пользованія больныхъ свђжимъ воздухомъ устраиваются временные бараки. Вообще, медицина находитъ свђжій воздух лучшей охраной здоровья человька, чьмъ можно объяснить обязательное примьненіе вентиляторовъ во всьхъ техъ помђщеніяхъ, гдђ находится человђкъ, какъто: въ больницахъ, на фабрикахъ, заводахъ и жилыхъ помещеніяхъ.курильщикъ же говоритъ: «НЬть, не нужно человђку свђжаго воздуха» и курить, наполняя воздухъ смраднымъ дымомъ. И какое, въ самомъ дьль, безуміе въ льтнее утро или вечеръ, такъ изобилующіе свђжестью драгоцьннаго воздуха, табачнику выходить съ трубкою или сигарою во рту, окружать себя табачнымъ дымомъ и какъ бы говорить: «Человьку вовсе не нужно такого свђжаго, полнаго наслажденія воздуха, какого Бог далъ!» и, продолжая курить, лишаеть и другихъ этого дара Божія. Воть въ большихъ городахъ для удобства публики заведены конно-жельзныя дороги, и другой, чтобы наслаждаться свђжимъ воздухомъ, береть место наверху конки, на открытомъ воздухь, но рьдко такое благо и совершенно цьлесообразное намьреніе бываеть удачно, ибо тутъ-то и встрьчаются табачники и первымъ ихъ дьлом - куреніе этого зелья. Какъ нужно благодарить умное и вполнь справедливое распоряженіе нашего Г. Министра путей сообщенія за его приказаніе не пускать курильщика въ вагонъ некурящихъ, а имьть для нихъ отдђльные вагоны, а то отъ нихъ въ пођздахъ пощады не было. И поистинь такая жестокость со стороны курильщиковъ: вагоны бываютъ переполнены народомъ, людьми, не терпящими табачнаго дыма, женщинами и слабыми дЂтьми, которыя начинають кашлять, какъ естественный протестъ, противъ изобрьтенія человьческаго ума, а курильщикъ и знать не хочеть и считаеть себя въ полном правь продолжать свое мнимое наслажденіе, доставляющее другим столько неудобствъ и непріятностей, а иногда на просьбы матерей не курить вблизи ихъ дЂтей слабогрудыхъ и бользненныхъ, курильщикъ считаетъ таковыя просьбы не заслуживающими удовлетворенія и даже посягательствомъ на его личную свободу.

«К чему-же Богь произрастиль табакъ?» - защищаются прихотливые курильщики, а мы скажемъ: мало-ли родовъ растеній произрастаетъ намъ мать земля. Нちкоторыхъ трав свойства и назначенія намъ уже извьстны, а некоторыя еще не изсльдованы. Одни травы бывають 
питательны и цьлебны для человька, а другія - могуть служить на пользу звьрямъ и наськомымъ. Что табакъ не есть питательное растеніе, это уже подтверждается медицинскою наукою; если же онъ цьлебнаго свойства, то употребленіе его не должно быть постоянно, но временное, смотря по нуждђ, то есть должно употреблять въ извђстныхъ количествахъ, смотря въ какомъ состояніи находится организмъ чловька и по опредђленію медицины.

Противъ вышеизложеннаго немногіе будуть спорить и стараться доказать противное; они, пожалуй, согласятся, что табако-куреніе есть вредная привычка, посльдствія которой бывають весьма печальны, какъ въ отношеніи благосостонія отдБльныхъ людей, преданныхъ ей, такъ и въ отношеніи цђлаго народа, такъ какъ народъ вђдь и состоить изъ отдђльныхъ лицъ.

Но надо ожидать, что многіе возмутятся противъ посльдней мысли, что табако-курильщикъ - орудіе въ рукахъ сатаны, врага нашего спасенія.

«Какимъ образомъ, - скажут, - мы, курильщики, сообщники сатаны есмы? Какая смђлость сказать подобное?» Такія возраженія весьма часто приходится слышать оть пристрастниковъ къ чему-либо, которые просять непремьнно указать буквальный тексть въ книгахъ Св. Писанія противъ извђстнаго общественнаго порока, но потому только они такъ говорять, что они потеряли твердую почву вьры. Противъ табаку не можеть быть упомянуто въ Св. Писаніи уже потому, что табако-куреніе только стало извьстно цивилизованнымъ народамъ, какъ я уже говорилъ выше, лишь съ XV стольтія посль Р. Х., но я только и предлагаю мою брошюру в рующимъ, то есть истиннымъ христіанамъ, а таковые, конечно, знають, что всякое излишество, лишеніе себя или другихъ здоровья, необходимаго условія въ счастьи человеька, - уже есть грьхъ, а сльдовательно, также и исполненіе желанія сатаны, или сообщника его. А еще скажуть: если на табако-куреніе смотрђть, какъ я смотрю, то какъ же это на сборищахъ у лучшихъ людей свьта допускается и принято куреніе? «Послушай, собратъ мой христіанинъ, мало-ли что дьлается на сборищахъ у таъ называемыхъ лучшихъ людей свьта; тамъ и винопитіе не въ мьру, и картежная игра, и всенощная пляска... Неужели, положа руку на сердце, станешь утверждать, что все это хорошо и достойно подражанія? НБть... Печально и достойно оплакиванія видђть, что руководители и наставники народа вмьсто того, чтобы бороться съ такимъ зломъ, служать еще соблазномъ. Весьма похвально поступають ть благочестивые христіане, которые не дозволяютъ въ своихъ квартирахъ курить, такъ какъ это, дђйствительно, есть нерадђніе и даже оскверненіе святыни, которая находится въ домахъ христіанъ, какъ лики Спасителя, Пречистой Его Матери и Св. угодниковъ Божіих. А то нерьдко приходится видьть въ домахъ тотчасъ посль молебновъ, на имянинахъ или крестинахъ, что пристрастные табачники приступають къ воскуренію сатань тамъ, гдь за ньсколько минутъ воскуривался фиміамъ Богу и Спасу. Куреніе же табаку на оградахъ церковныхъ и на паперти, развь хорошо и не осквернительно для чувства истиннаго христіанина? Идешь въ храмъ Божій, стараешься уже на пути приготовиться къ священнодђйствію, отогнать козни діавольскія оть сердца, ума и воли твоей, чтобы достойнымъ образомъ поблагодарить Господа за изліянныя на тебя и любимыхъ тобою неисчисленныя милости, просить для себя и другихъ прощенія грьховъ, благодати и милосердія Божія; уже приближаешься къ церкви съ благоговьйнымъ чувствомъ и сокрушеніемъ сердца, вздохи невольно вырываются изъ сердца твоего какъ знакъ благодати Божіей, приближающейся къ тебъ; но туть-то на паперти церковной стоятъ курильщики и предаются, вблизи милосердія Божія и видимаго присутствія Его, своей пагубной и богопротивной прихоти. Да, вьрю тебь, христіанинъ, что ты ужасаешься при видь этого. Тебь становится обидно за святость мьста и нарушенія благочинія въ домь Господнемъ, но ты не смђешь спорить, опасно заступиться и св. вера твоя и домъ Божій должны быть въ поруганіи, да еще оть кого?.. от своихъ же присныхъ единовђрцевъ. Обыкновенно удары сильнье чувствуются, если они бывают оть друга, чемъ отъ врага. Еще обидно и то, что на твой справедливый протесть ты слышишь поруганіе и осмьяніе, да еще изрБдка оть людей, не достигшихъ совершеннольтія, 10-12-льтнихъ мальчиковъ. Да, собрать мой, грустно, потому именно, что это порокъ общественный; зараза приняла весьма широкіе размћры и борьба неравная. Князь міра сего силенъ на время, а приверженцы и сообщники его сьютъ этотъ смертоносный ядъ направо и нальво. Со стороны злодьятелей и богопротивниковъ употребляются всь усилія, чтобы сьять мракъ и болье угодить діаволу, «ибо сыны вька сего мудрье сынов свђта» (Лука, 16.9).

Для всякого рода предпріятій, имьющих цьлью наживу или удовольствія, находятся люди, и капиталы, и время. Для борьбы же со зломъ, для защиты вьры и нравственности народа - не находится ни людей, ни средствъ. Что хорошо и полезно, можно заимствовать отъ другихъ народовъ. Вотъ, за границей, а особенно въ Англіи, сушествуютъ общества и кружки для борбы съ пороками общественными и для удержанія и утвержденія доброй нравственности въ народђ, напримеръ, против пьянства, табако-куренія и другихъ пороков. Мы же перенимаемъ все что угодно отъ другихъ народовъ: и моды, и усовершенствованія въ дБлахъ промышленности, и удобства въ жизни, но что касается до нравственности народа, то какъ будто намъ и дђла ньтъ.

Подражаніе, вообще, не подобаетъ существамъ разумнымъ, у нашей же просвђщенной части населения (конечно, свђтско-просвђщенной) слишком замћтна страсть къ подражанію всему иноземному и печальнье то, что все подражаніе состоить въ томъ, что наносить большой ущербъ народному благосостоянію и наносить чувствительный ударъ общественной нравственности. Свое-же доброе, старое забывается, или предается открыто уничтоженію.

Оставить вкоренившійся порокъ трудно только до тьхъ поръ, пока почва вђры не прочна въ сердце человђка, пока не омраченъ и человькъ видить счастье въ чувственности и мірскихъ наслажденіяхъ; страхъ же Божій и загробная жизнь забыты, пока сердце не внимаеть любви Небеснаго Отца и не размышляеть о промысль Божіемъ, - цьли и назначенія жизни человька на земль. Человьку же, истинно вьрующему въ Бога, часто 
помышляющему о любви Небеснаго Отца къ ниспадшему роду человьческому, человьку, достойно оцьнивающему крестныя страданія своего Господа и Спсителя (насколько это возможно человьку), вникающему его божественному голосу: «Вы есте (Матө, 5.14) свђть міру», конечно, какъ свђту должно свђтить, а не окружать себя мракомь табачнаго дыма, который омрачаеть умъ и притупляеть умственныя способности человька.

Теперь табачникъ-христіанинъ, если ты прочтешь внимательно мою брошюру и вникнешь въ смысль моей бесьды, то ты поймешь, конечно, какъ табако-куреніе вредно для здоровья и какой громадный ущербъ оно наносить народной нравственности, и потому будешь стараться искоренять это зло, надБясь на Господа, который укрьпить и утвердить тебя на этомъ добромъ, достойном христіанина пути, согласно словъ Апостола Павла: «Все могу во укрьпляющемъ меня Іисусь Христь» (Пос. Филип. 4.13).

Примьчаніе. Кстати я могу указать вамъ ть средства, которыя употреблялись курильщиками для того, чтобы отучить себя оть куренія. Во время позыва къ куренію надо съ屯сть какіе-либо сладкіе фрукты (яблоки, сливы, груши и т. п.). Это средство доступно каждому курильщику, потому что оно только нужно въ начале оставленія куренія, а сравнительно съ потерей здоровья отъ табако-куренія и расхода на самый табакъ, расходъ на фрукты окажется совершенно ничтожнымъ».

\section{«ПОУЧЕНІЕ ПРОТИВЪ ПЬЯНСТВА»}

$$
\text { (1891 г.) }
$$

«На піанство вооружимъ языкъ и обличимъ въ немъ действующыя: не яко да посрамимъ ихъ, но да тьхъ отъ срама премьнимъ: не яко да поносимъ Тьхъ, но яко да ТЬхъ исправимъ».

Св. I. Щлат. въ Маргар. лис. 186

«Когда пьяный придеть въ чувство, опиши все его безобразіе. Тちхъ, кои заразились пьянствомъ, исхищайте изъ бьды, дабы не было между вами людей, которые хуже безсловесныхъ» (Св. Іоан. Злат. въ бесьд. на Еван. оть Мат. Моск. 1859 г. II, ст. 488). Братіе христіане, согласно съ симъ наставленіемъ вселенскаго учителя, мы, духовные ваши отцы, по долгу нашему, въ предостереженіе ваше, желаем побесьдовать съ вами объ этомъ ужасномъ порокь - пьянствь. Кто самъ ему подверженъ, позаботься о себь и остерегись! Кто, благодареніе Богу, не подверженъ этой слабости, пожальй и предостереги другаго! Вы знаете, какъ на страшномъ судь Господь наградить милостливыхъ, а спасти ближняго отъ гибельнаго порока - пьянства, это великое дьло милосердія!

Пьянство само говоритъ о своемъ безобразіи. Посмотрите на пьянаго: если онъ еще на ногахъ, какія говорить глупости, какія дђлаетъ нельпости! А между ТЬмъ доволенъ собою и еще обижается, что его не слушають, не забавляются его нескладными рьчами и поступками! Хочешь его остановить, онъ сердится, начинаеть браниться; придирается ко всякому встрђчному, знакомому и незнакомому: то униженно кланяется, то безъ всякой причины бранится. Какой позоръ!.. Какая жалость! А когда дойдеть до безчувствія, тогда и совђсть и стыдъ, и даже чувство самосохраненія - все пропадаеть въ немъ! А вЂдь это человђкъ, созданный по образу Божію и по подобію. А вьдь это христіанинъ, освященный благодатію Духа Святаго въ таинствахъ крещенія, миропомазанія, причащенія!.. Это христіанинъ, который чаеть воскресенія мертвыхъ и жизни будущаго вちка, обращаеть себя, можно сказать, въ скота! «Ибо, говориль Св. Іоаннъ Златоустъ, - скоты не требують ничего более того, что нужно; а сіи (то есть пьяные) становятся безсмысленнье оныхъ, преступая границы умьренности. И подлинно, не гораздо ли лучше таковыхъ людей осель? Не гораздо ли лучше песъ? Каждое изъ сихъ животныхъ и всь прочія вообще, ьдять ли, пьють ли, знають предђл довольства и не простираются далье нужды. И хотя бы тысячи человькъ принуждали ихъ, никогда не дадутъ себь дойти до неумьренности. И такъ, вы хуже безсловесныхъ... это видно изъ того, что сихъ животныхъ не заставляетъ ђсть сверхъ мьры. Почему же это такъ, спросять? Ты скажешь, чтобы не нанести имъ вреда, а о себь ты этой предусмотрительности не употребляешь. И такъ, ты думаешь о себь хуже, нежели о скотахъ, и всегда обуреваемый нерадишь о себђ» (Тамъ же, стр. 483). Спаси, Господи, всякаго оть такого позора и такой бъды!

Теперь представьте, что должно быть съ человђкомъ, если онъ привыкъ быть часто пьяным. Съ ранняго онъ чувствуеть себя какъ бы нездоровымъ; ему чего-то недостаеть; онъ какъ будто голоденъ! Спьшитъ скорье выпить и принимается за дьло! Хмьльный, съ тяжелою головой, работаетъ безъ охоты, безъ рассужденія и много портить. А тут страсть опять зоветь его къ вину! Затемъ следуеть полное опьяненіе, совершенно омраченіе разсудка и неспособность къ работь! Хотя, можетъ быть, онъ и умный мастеръ своего дђла, но какая польза оть его ума и его искусства, когда вся жизнь его проходить во хмђлю да похмьльђ. Гибнетъ таланть его, зарыль онъ его въ землю, и дасть за то отвьть Господу!

А сколько вреда дђлаеть своему здоровью человђкъ, преданный пьянству! Какъ укорачиваеть жизнь свою! Нちтъ такого крђпкаго здоровья, котораго не сломило бы пьянство. Одни изъ людей, пристрастныхъ къ вину, подвергаются бБлой горячкь, Въ которой дьлаются подобно сумасшедшимъ; другіе оканчиваютъ чахоткою; иные умираютъ отъ удара, который вдругь и неожиданно прекращаетъ жизнь ихъ! Кромь того, что пьянство само по себь сокращаеть нашу жизнь, пьяный обыкновенно не бережетъ самъ себя - стало быть, легко подвергается разнымъ другимъ повержденіямъ и бользнямъ. Если разобрать, оть чего у людей произошли разныя поврежденія: разбитое лицо, испорченный глазъ, изувеченная рука или нога, окажется, что большая часть нажили увьчье во хмьлю (Притч. XXIII. 29, 30).

Вредъ оть пьянства не останавливается на одном человькь, подверженномъ этому пороку. Зло пьянства черезъ него разливается и на другихъ людей. Прежде всего пьянство разжигаеть въ человькђ нечистую, плотскую похоть. Потерявши отъ вина разсудокъ, пьяный не боится грђха, о которомъ можьть быть прежде боялся и думать. Потому и Апостоль говорить: не упивайтеся виномъ, въ немъ же есть блудъ (Ефес. V, 18). 
А сколько злодђйствъ и звђрскихъ убийствъ совершается людьми оть пьянства! Оно доводить и до воровства, и до грабительства, и до всякаго другаго преступленія. Если узнать навьрное, отчего многіе злодђи дошли до преступленія, окажется, что большая часть ихъ, начавши съ вина, дошли до пьянства, сдђлались ворами, а потомъ грабителями и убійцами.

А каково хозяйство у человька, преданнаго пьянству? у кого ньтъ лошади или коровы? У кого домъ или дворъ стоять раскрытыми? Или у безпомощной вдовы, или у пьяницы. За кьм недоимки? За кого платитъ общество? Опять за того же пьяницу! Вдовы и сироты имьють право на состраданіе и помощь общества; но пьяница не имћеть права на милость общества, хоть и пользуется ею: онъ ћсть даромъ чужой хльбъ, когда бы самъ могь кормить другихъ. Какъ раззоряеть пьянство, это можно видђть на цьлыхъ селеніяхъ. Гдђ много пьютъ, какой видъ представляють тамъ села и деревни! Вездь пустота, запущенность и бездомовность. Дома безъ дворовъ; кровли на половину раскрыты - ни сада, ни огорода! Какъ раззоряетъ пьянство крестьянина, такъ же точно раззоряеть и ремесленника и всякаго другаго человька. Богатства и порядка пьянство никакого не приносить. Оно ведеть съ собою праздность и льность, небреженіе къ собственнымъ выгодамъ и положительное мотовство; а за нимъ и въ хорошія хозяйства войдетъ недостатокъ и нужда: всякъ пьяница и блудникъ обнищаетъ, сказано въ Писаніи (Притч. XXIII, 21).

А что же можеть быть жальче семьи пьянаго человька? Надъ покойником не прольють столько слезъ, сколько придется пролить ихъ жень и детямъ пьющаго человька. Ни одинъ больной не надьлаетъ столько хлопоть и заботь семьђ своей, сколько наделаеть ихъ пьяный человђкъ. Да и вообще, никакой врагь не надђлаеть столько зла своей семьђ, сколько сдђлаетъ онъ самъ. Жена и дьти терпятъ крайнюю нужду и голодъ отъ того только, что мужу нужно вино. Жена жалуется на разорительное пьянство, а мужъ или безъ чувства или смысла смьется надъ жалобами жены, или еще какъ правый сердится на жену, а иногда начинаетъ бить ее чем попало, какъ будто отъ его брани и побоевъ семья будетъ сыта и довольна! По вечеру жена должна ждать пьянаго мужа; иногда отыскивать его; она боится, чтобы с пьянымъ не случилось какой бъды; она должна бросить дђтей своихъ, чтобы няньчиться съ пьянымъ мужемъ, который за всь ея заботы заплатить ей только бранью или побоями... Господи, Господи! И такъ много горя на земль, и такъ много нужды и заботь бБдным женамъ и матерямъ; а тут еще и мужъ дьлаетъ новое горе и новыя заботы, - мужъ, который долженъ отстранять отъ семьи своей всь нужды и всякое горь, который долженъ любить и беречь жену и дБтей, защищать и покоить ихъ. Терпите, терпите, бъдныя жены, и молитесь Богу; ваши слезы дойдуть до Бога! Он вразумитъ вашихъ мужей! Молитесь, молитесь матери, чтобы помиловалъ Господь дђтей вашихъ, чтобы не пошли они по грђшнымъ сльдамъ отцовъ своихъ, чтобы нужда и горе, какія они перенесли, научили ихъ не дђлать другимъ того же горя и нужды, а беречь другихъ оть горя, чтобы дурной примьръ не заразилъ ихъ, а научиль добру!..

Многомилостиве Господи! Церковь скорбить, видя, какъ гибнуть оть пьянства многія чада ея, цьлые семьи и селенія, - гибнуть здђсь, и обрекають себя на вьчную гибель; ибо пьяницы царствія Божія не наследять (1 Кор. VI, 10). Что-жь они насльдятъ? - Одно вьчное мученіе въ страшномъ адскомъ пламени (Лук. XVI, 24). Умилосердись надъ ними, Господи, и ими же вђси путями, останови и прекрати это страшное зло!

Аминь».

\section{«ПЬЯНСТВО-ОКАЯНСТВО»}

(1893 г.)

«Часто приходится слышать: радъ бы въ рай - да грђхи не пускаютъ! Такъ и ты верно говоришь: радъ-бы остановить пьянство и сопряженныя съ нимъ Богопротивныя дђла, но привычка слабость... хочу спасти душу свою, да не могу!..

Такъ позволь мнь на это сказать тебь, что слова твои лишены здраваго разума и смысла. Что обыкновенно дБлаешь ты, когда хочешь избавиться оть тяготьющаго надъ тобою бьдствія, или бользни, или другой какойлибо напасти?

Ты скажешь, конечно: я стараюсь употреблять всь мБры къ тому, чтобы избавиться отъ тяжкаго моего положенія. Точно так же дБлай и поступай противъ твоего пристрастія къ вину - это отрава христіанскихъ душъ! Вообще всь пьяницы много говорятъ о ихъ желаніи оставить этотъ гнусный порокъ, а сами ничего не придумають, чтобы действительно его оставить. Они только что не ищуть средства къ отрезвленію своего ума и отрБшенію своей злой воли оть этой пагубы, но рады случаямъ, чтобы напиться пьяными и своими поступками уподобиться несмысленнымъ скотамъ. Ибо кто это?

Человькъ-ли это, который валяется въ грязи, лишенный здраваго разума и воли, и который не понимаеть словъ человьческихъ, и котораго въ свою очередь не понимають другіе? Конечно, это не человБкъ, а животное неопределеннаго еще названія. Человькъ-ли это, который своимъ гнуснымъ поступкомъ, всльдствіе своей пагубной страсти, губить не только свою жизнь, но и единокровныхъ своихъ, отнимая нерьдко посльднее отъ единородныхъ своихъ?

Конечно, - скажешь ты, - звђрь, не имђющій чувства любви и жалости.

Человькъ-ли это, один видъ котораго уже внушаеть страхъ и опасеніе за свою жизнь всьм встрьчающимся съ нимъ. Не хищный ли это звьрь, который нападаетъ, чтобы разрушить, уничтожить не только предметы житейскіи, но и самую жизнь людей, ни въ чемъ неповинныхъ и даже питающихъ къ нему чувство любви и сожальнія, как-то: жены и дђтей, на которыхъ обезумћвшій отъ вина нападаетъ съ сатанинскою силою, чтобы терзать и губить. Да, во истинь, если есть что гнусное между людьми - то это пьянство! Пьяница живетъ, существуеть для того только, чтобы собрать себь гнћвъ на день гнђва и страшнаго суда Божія (Римл. 2.5).

Пьяница - это точно идоль, имьеть уши и не слышитъ, имђетъ глаза и не видить, имћеть ноги, но которыя отказываются служить ему, руки, которыя не дちйствують. Одинъ только голосъ иной разъ слышно, но не человђческій, а звђроподобный, точно ревъ 
хищнаго звьря. И живеть себь пьяница, именующійся христіаниномъ, - безъ Бога, безъ Христа и безъ надежды въ мірь.

Въ праздничный день церковь призывает в ьрующихъ на пиръ вђры, а пьяница спђшитъ на пиръ нечестивцевъ. Въ церкви вьрующіе устами прославляють Бога, а пьяница дерзаеть открывать свои уста, чтобы осквернить воздухъ Божій бранью и гнилыми словами на радованіе бћсов? Церковь предлагаеть чашу спсенія, а пьяница и знать ее не хочетъ, а стремится къ чашь гнђва Божія. Но возможно ли описать всю гнусность и Богопротивность жизни и поступковъ пьяницы? И какъ ихъ вразумить и чьмъ ихъ убьдить, когда они сами не желають и вразумленій не понимаютъ! Имъ говоришь о ихъ погибели, а они въ отвђтъ какую-нибудь шутку сострятъ; напомнишь имъ о Боґ, а они говорять - мы все это знаемъ. Да, на слова и вздохи они щедры, а своими дђлами стремятся къ бъсу и вьчной гибели.

Посль всего сказаннаго мною довольно будетъ, если еще сказать тебь, что ты, пьяница, если намьренъ продолжать свою Богопротивную жизнь, то на вБки погибнешь! Будетъ Страшный Судъ Христовъ - боишься ли ты, или не радиши о немъ? - по дђламъ твоимъ воспріимеши - признаешь-ли или ньтъ? Адъ и муки вђчныя существуютъ для сыновъ погибели, и пьянство туда тебя ведетъ ближайшимъ и вђрнђйшимъ путемъ. Во всемъ этомъ убьждаеть насъ слово Божіе и бывшее уже наказаніе на противниковъ Божіихъ. Бог поругаемъ не бываетъ (Гал. 6, 7), - говоритъ Апостолъ Христовъ! Божіе прощеніе рано ли поздно и тебя постигнеть, несчастный! Возстани спящій въ нерадђніи о душђ своей и воскресни изъ мћртвыхъ, ибо ты воистину мертвый для Бога и вьчной блаженной жизни - и освятить тя Христосъ Богь вездђ и вся исполняй! Твоими силами ты не можешь встать и быть живымъ членомъ тьла Христова, то есть Его Церкви. Но моли Господа, говоря: Боже, милостивъ буди мнь грђшному! Господи! Не остави мене! И Господь по благости и человьколюбію Своему услышитъ моленіе твое, оть искренняго сердца возносимое, и ты получишь Просвьщеніе и освященіе. Сердце чисто созижди во мнь Боже, и духъ правъ обнови въ утробь моей (Псал. 50.12). Куда спБшишь, куда стремишься ты, русскій ремесленникъ, рабочій, въ Воскресный день? Звонъ Церковнаго колокола не доходить до ушей твоихъ, обязанность христіанина не стучить въ дверь сердца твоего? Повидимому, ты, христіанинъ, крестное знаменіе творишь неоднократно, а на зовъ церкви не отзываешься. Святыя Тайны не признаешь нужнымъ для себя. Гдђ причина твоей холодности, твоей безпечности, - твоей неблагодарности, къ Тому, Который такъ видимо благодьтельствоваль тебь, твоему Отечеству, твоимъ Царямъ. Подумай - ты одержимъ такимъ недугомъ, который силенъ разрушить не только твое собственное благосостояніе, но и семейное и общественное! Недуг, который долженъ окончиться непремьнно смертію временною, а затьмъ и вђчною, - это пьянство!

Въ одно воскресенье, утромъ, выходя изъ дома, увидьлъ я одного ремесленника, выходящаго изъ своего дома и спьшившаго куда-то. Проходя часто мимо окна его мастерской, гдђ онъ работаеть, и видя его постоянно за работою, я теперь недоумьваль, увидьв его бользненный видъ лица, вмьсто сапог опорки, лохмотья еле прикрываютъ его тьло и его самого, дрожащаго какъ оть сильной лихорадки, шедшаго скорымъ шагомъ. Сльдуя за нимъ, я долго не могь рђшить свое недоумћніе. Чувство сожальния сильно тьснило мою грудь о моемъ соотечественникь-труженикь. Не болезнь-ли подтачила здоровье повидимому дюжаго человька? Не семейныяли обстоятельства заставили этого человђка одьться кой какъ и прикрыть наготу свою? Такъ думалъ я, сльдуя за нимъ. Но не долго былъ я въ недоумћніи, нђсколько минутъ времени уяснили мнђ причину бђдствія этого человька. Отойдя шаговъ на пять-десять, вижу я, онъ завернуль въ ближайшій трактиръ, гдђ выпилъ за гривенникъ полный чайный стаканъ водки, называемой "русское добро". Это такое добро, православные, которое бываетъ причиною всякаго зла и несчастія, которое отнимаеть отца-кормильца оть семьи, которое человђка превращает въ звьря, родного отца и мужа - въ тирана, христіанина дьлаеть - хуже невьрнаго, который позорит наше дорогое отечество, осмђиваеть Христа и Церковь Его Святую, за которую пролита драгоцьнная кровь Спасителя на Кресть. Да, Богь долго терпить, но бываеть предьль Его долготерпьнію!

Православные, ревнующіе о Господь и Вђрь Святой, подымите вашъ взоръ и посмотрите на погибающій въ пьянствђ русскій народъ! Помолясь Господу, подумайте - не можете ли общими силами, или личнымъ содђйствіемъ, помочь столь великому горю; ослабить, если не уничтожить, этотъ недуґ, эту язву семейную и общественную? Апостоль повельваеть всьмъ вразумлять безчинныхъ, обратить грђшниковъ оть ложнаго пути ихъ (Іаков. 20).

$\mathrm{Bъ}$ настоящее время рђдко встрђчается русскођ семейство, котораго не коснулось бы разрушающее дちйствіе пьянства. Не пора ли серьезно подумать объ этомъ? Помните, что пьянство ведетъ къ распутству, которое осльпляетъ человђка, и какъ узникъ, самъ не въ силахъ освободиться, но другіе должны хлопотать и содђйствовать его освобожденію, так и узникъ діавола, врага нашего спасенія, требуеть нашего содђйствія духовнаго и нравственнаго. Богь вамъ укажеть путь. Он же и силенъ, обогатить васъ всякою Благодатію къ совершенію добрыхъ дђлъ - временнаго и вьчнаго блага ближняго.

Вы члены одного тьла: если одинъ членъ страдаеть, говорить Апостол Христов, - и всь остальные съ нимъ страдають (Коринф. 12.26). Сльдовательно, никто не долженъ говорить - не мое дђло, пускай губить себя пьяница, если ему угодно, а мнь то что! Такія слова можеть говорить только тоть, который не понимаеть сущности христіанской вђры.

Христіанинъ должен пребывать въ любви со всьми, иначе онъ ничто по слову Апостола, и даже жертвы такого христіанина непріятны Господу; а потому долженъ всячески стараться объ исправленіи брата своего. Вы есте соль міра (Мат. 5.13), и как соль предохраняеть предметы пищевые оть гніенія, такъ и христіанинъ долженъ оберегать присныхъ своихъ оть духовнаго гніенія безвьрія и распутства. ВБрно и всякаго пріятія достойно слово, что Христосъ Іисусъ пришелъ въ міръ грьшниковъ спасти (Тимоф. 1.15). Въ этихъ словахъ Апостола прямое 
для христіанина побужденіе къ ревностной дьятельности касательно вђры и нравственности; а для отступниковъ и нерадивыхъ христіанъ - надежда на милость Божію къ истинно-кающимся и желающимъ вступить на путь спасенія. Сими словами ободритесь и вы, пьяницы. Оставьте такъ губящее васъ пьянство скорье, не медлите обратиться къ Богу съ мольбою и слезами - да помилуеть васъ, пощадить и сохранить души ваши для вьчной жизни.

Живъ Господь - нехощу бо смерти грьшника, но еже обратитися, ему и живу быти (Іезек. 18.22).

Господи, помози всьмъ и каждому!»

Анализируя последствия табакокурения и махоркокурения, следует отметить, что в табаке и в махорке содержатся несколько алкалоидов, основные из которых никотин, норникотин и анабазин, и сопутствующие норникотирин, никотирин, миозмин, анабазин и котинин.

\section{Разобщение общества и природы и вызванные} им проблемы

Общепонятно, что со времени начала индустриальной революции - научно-технической и научно-технологической революции в целом, охватившей все стороны, формы и проявления жизни и деятельности как отдельного человека, так и всего общества, в результате в большинстве случаев недостаточно обоснованных, а нередко и полностью необоснованных деяний - проектов и их решений, произошло предсказываемое естествоиспытателями и социологами разобщение общества и природы, оказавшее значительное влияние не только на генетический фонд растений, животных и человека, но и на заболеваемость человека, включая заболеваемость нервной системы и нарушения психики [22, 66, 67, 93, 243].

Анализируя разобщение общества и природы, необходимо ознакомиться с содержанием вышедшей в свет в 1866 году книги «Человек и природа, или О влиянии человека на изменение физико-географических условий природы», автор которой - Георгъ Маршъ, а издатель - Поляковъ (Санкт-Петербург, 1866. - 592 с.).

Очевидно, что поведение отдельных людей и всего населения, обусловившее разобщение общества и природы, предопределяется в том числе и мерой потребления ими наркотиков, психотропных средств, алкоголя, табака и махорки, вызывающих зависимость от них. В связи с этим весьма показательна оценка этого потребления в соответствии с экспериментально апробированным законом Арндта-Шульца [241, 264], отражающим соотношение дозы действующего начала и вызываемого этой дозой биологического следствия. При незначительных, малых дозах раздражение вызывает стимулирующий эффект - стимуляцию активности. При больших дозах действующего начала вызываемый им эффект оказывается депрессивным, парализующим. Кокаин, например, при многих разведениях приводит к возбуждению, увеличению подвижности, учащению дыхания, усилению сосудистой пульсации и т. д. В то же время при больших дозах воздействия кокаин инициирует паралитические явления, сонливость, упадок сердцебиения, дыхания и кровяного давления. Морфий при малых дозах возбуждает рвотный центр, а при больших дозах морфий этот центр парализует. Действие алкоголя сопоставимо, причем на многие организмы, включая протисты и растения. Оправдано подчеркнуть, что употребление кофе, кофеинсодержащих продуктов, алкоголя, а также курение в сроки беременности инициирует тератогенез конечностей, ретардацию развития плода, уменьшение массы тела новорожденного, мертворождение и так называемый алкогольный синдром плода [10].

C XIX столетия стало признанным и непререкаемым, что любые проблемы познания человека (человековедения), чему би они не были посвящены, должны иметь в своей основе генетику, в частности, генетику человека и ее самостоятельный раздел медицинскую (клиническую) генетику. В настоящее время очевидно, что необходимы и эпигенетические исследования [18, 26, 65, 67, 226, 315, 319, 322].

Генетические и эпигенетические эксперименты и анализы и установленные в их итоге сведения - условие объективной разработки и объективного понимания многих аспектов взаимосвязанных друг с другом проблем контроля за незаконным оборотом наркотиков и психотропных средств, проблем алкоголизма, табакокурения и махоркокурения, в связи с чем обязательны, во-первых, организация и осуществление соответствующего мониторинга [194] и, во-вторых, организация и осуществление соответствующего медико-генетического консультирования [51, 178, 306]. При этом в процессе упомянутого мониторинга следует учитывать, что активные опийные наркотики производятся их потребителями, в частности, е только из плодов Papaver somniferum L., но и из содержащихся в этих плодах семя [240].

Следует отметить, что на содержание опийных алкалоидов в Papaver somniferum L. значительное влияние оказывают паразитические фитонематоды, инвазирующие корни, в том числе: Plectus granulosus (Bastian) de Coninck et Stekh., Monhystera agilis de Man, Monhystera bulbifera de Man, Prismatolaimus dolichurus de Man, Prismatolaimus intermedius (Bütschli) de Man, Mononchus papillatus (Bastian) Cobb., Dorylaimus filiformis Bastian, Eudorylaimus acuticauda (de Man) Andrassy, Eudorylaimus obtusicaudatus (Bastian) Andrassy, Audorylaimus papillatus (Bastian) Andrassy, Eudorylaimus paraobtusicaudatus (Micol.) Andrassy, Mesodorylaimus bastiani (Bütschli) Andrassy, Dorillium uniforme Cobb., Alaimus primitirus de Man, Diphtherophora communis (de Man) Goodey, Rhabditis brevispina (Claus) Bütschli, Rhabditis intermedia de Man, Cephalolobus persegnis Bastian, Mesodiplogaster itheritieri (Maupas) Goodey, Eucephalobus elongates (de Man) Thorne, Eucephalobus oxyuroides (de Man) Steiner, Eucephalobus striatus (Bastian) Thorne, Chiloplacus symmetricus (Thorne) Thorne, Acrobeloides buetschlii (de Man) Steiner and Bührer, Acrobeloides uberrinus Anderson, Panagrolaimus hyagrophilus Bassen, Panagrolaimus rigidus (Schneder) Thorne, Panagrolaimus subelongatus Cobb., Aphelenchus avenae Bastian, Paraphelenchus pseudoparietinus (Micol.) Micol., Paraphelenchus tritici Baranovskaja, Aphelenchoides fragariae (Ritzema Bos) Christie, Aphelenchoides parietinus (Bastian) Frranklin, Aphelenchoides saprophilus Franklin, Aphelenchoides subtenuis (Cobb.) Stener, Aphelenchoides subparietinus Sanwal, Tylenchus Agricola (de Man) Andrassy, Tylenchus davainei (Bastian) Andrassy, Aglenchus costa- 
tus (de Man) Andrassy, Tylenchus filiformis (Bütschli) Filipjev, Neotylenchus abulbosus (Steiner) Goodey, Hexatylus viviparous Goodey, Nothotylenchus acris Thorne, Helicotylenchus multicinctus (Coob) Golden, Helicotylenchus nannus Steiner, Pratylenchus montanus Zubin, Pratylenchus scribneri Steiner, Pratylenchus vulnus Allen and Jensen, Heterodera schachtii Schmidt, Criconemoides tenuiannulata (Tulaganov) n. comb., Paratylenchus hamatus Thorne and Allen, число видов которых 56 - представителей подклассов Adenophorea и Secernetea, отрядов Chromadorida, Enoplida, Rhabditida и Tylenchida, 21 семейства и 35 родов [13]. Фитонематодная инвазия корней вызывает безопийность («эркечность») опийного мака, которая достигает почти 39\%. Причина безопийности - ферментативное окисление млечного сока, инициирующее ее коагуляцию, - следствие заражения фитонематодами. Выявленное нарушение - указание на возможную паразитарную технологию достижения безгашишности.

Контролю должны подлежать не только наркотики, но и любые сильнодействующие на организм человека вещества, подобные, например, гормонам, мутагенам, канцерогенам, тератогенам, стимуляторам и ингибиторам роста и развития [127]. Осуществляя генетически и эпигенетические исследования организма человека, важно осознавать, что необходимо принимать во внимание и возможности плазматического - внеядерного, внехромосомного наследования [35, 217, 304].

Для предотвращения наркомании, токсикомании, алкоголизма, кофеиномании, никотиномании в практике деятельности соответствующих организаций должны быть использованы психофармакологические и медикоправовые исследования наркотически активных и психотропных соединений и их биотрансформации, причем все вопросы должны рассматриваться с учетом возможностей психопрофилактики, психофармакотерапии и последующей психосоциальной реабилитации [41, 49, 56, 218, 221, 275, 288].

Специальное внимание должно быть обращено на личностные психологические отличия наркоманов, токсикоманов, алкоголиков и никотиноманов, на естественный полиморфизм наследственных болезней нервной системы и психики человека, на любые токсиканты - провокаторы противоправного поведения и, прежде всего, на нейротоксины, на перспективные антинаркотики, в особенности на те, которые разрешено вводить в организм больного человека, на психическую реактивность человека в целом [83, 133, 142, 234, 284]. Уместно отметить, что для выявления и количественного определения фитогенных алкалоидов (морфина, кодеина и т. д.) издавна и успешно применяется технология хроматографии на полиамидных сорбентах [291].

В настоящее время обращают на себя внимание возможности и условия применения для выявления и лечения наркоманов, токсикоманов, алкоголиков и иных криминальных личностей с помощью сорбционных технологий: количественного электрофореза, регионарной химиотерапии, регионарной перфузии и парентеральных воздействий [30, 55, 63, 73, 318]. Выявление наркоманов и токсикоманов реально и с использованием технологии применения жидких кристаллов, позволяющей осуществлять диагностику и возникающих патологических явлений - следствий криминальных пристрастий $[102,286,287]$. Такая возможность была отмечена и ранее [265].
Объективны перспективы лечения наркоманов с церебральными лимфомами - клинически выраженным результатом потребления наркотиков [292]. Принципиально важно отметить, что обоснованы условия разработки и создания системы этиологического диагностикума для выявления шизофрении, болезни Дауна и иных синдромов у каждого больного, причем синдромов не только генетически обусловленных [43, 84, 232, 233]. В основном установлены закономерности цитогенетических и генетических в целом последствий применения наркоманами в качестве наркотика лекарственных средств с выявленной мутагенной активностью - кофеина (1,3,7-триметилксантина) и теобромина (3,7-диметилксантина) - индукторов хромосомных аберраций, которые важны при лечении криминальных личностей. Существенное значение имеет выявление того факта, что сопоставимое влияние на наркоманов оказывают потребляемый ими в качестве наркотика диэтиламидлизергиновой кислоты, алкоголь и табакокурение, увеличивающие частоту аберраций хромосом [277]. Экспериментально установлено, что кофеин и теобромин наряду с уже отмеченными эффектами вызывают подавление митозов и отмирание клеток, причем оба эффекта зависимы от концентрации [109]. Кофеин также влияет на галлюцинацию [221]. Экспериментально выявлено, что в некоторых тест-системах кофеин оказывается не мутагеном, а антимутагеном [2]. Упоминая шизофрению, нельзя не привлечь внимание к ее оценке как информационного психоза. Такая оценка может оказаться одним из объяснений патогенетического механизма ее возникновения.

Со времени начала широкого и по существу всесветного распространения наркомании как тягчайшего по своим последствиям заболевания значительный интерес наркологов вызывает проблема установления порога насыщения организма наркоманов легкими наркотиками и их смесями (сочетаниями), в том числе и с учетом рецидивов наркомании, если такой рецидив после излечения у наркоманов наступает.

Представляет большой интерес сопоставление накопления в организме наркомана поглощенных им наркотиков и накопления в организме человека продуктов первичного метаболизма, так называемый тезаурисмоз [268]. Больные наркоманией и больные с болезнями накопления различны и накапливают в своем организме химически принципиально различные вещества. Вместе с тем, процесс накопления как процесс оправдано анализировать и сопоставлять, и результатом сопоставления может оказаться выяснение ранее не известных закономерностей.

Наркотики, с учетом их химической природы и распространения на всех континентах, естественно, вовлекаются в круговорот веществ в природе и в обществе - в глобальные биогеохимические циклы [38]. Тем самым болезни и причинно связанная с ними смерть человека (смерть - обычный итог жизни наркомана) оказываются, во-первых, обязательным объектом танатологического анализа [176, 314], и, во-вторых, тела умерших оказываются составляющими скоплений органического и неорганического вещества (учитывая химизм человеческого организма, подвергающегося естественному разложению).

Разлагающиеся органические и неорганические вещества вполне оправдано рассматривать, следова- 
тельно, с точки зрения тафономии как элементы тафоценоза, танатоценоза, мероциеноза и батибия [87, $100,325]$. Как вполне оправдано полагал В.И. Вернадский, одно из важнейших явлений природы - неразрывная связь мертвого и живого [58]. Было отмечено, что живое вещество может быть видовым - однородным и расовым - также однородным. Как видовое, так и расовое (внутривидовое) живое вещество представляет собой сгущение жизни. Примеры сгущения жизни на ограниченных территориях - посевы конопли, посевы мака, причем вне зависимости от отличий химического состава конопли и мака в пространстве их посевов и от времени высаживания. Упоминая существование сгущений растений в искусственных посевах и в естественных сообществах, важно привлечь внимание к особому феномену - толерантности к таким сгущениям, которая представляет собой самостоятельное явление [188].

Сгущениями живого вещества являются массовые посадки растений эфироносов, по существу любые одновидовые и многовидовые фитоценозы. Уместно отметить, что многосотлетнее использование наркотикосодержащих растений, в частности, конопли, в ритуальных национальных этнических целях, сведения о чем содержатся у этнографов классиков, например, у Л.П. Потапова, который сообщает, что у алтайцев в соответствии с их верованиями властитель Шаныру - богатый охранитель жилища и Алтая как такового, привязывает к нижней части своего изображения коноплю (продуцент каннабиноидов) [224]. Шаманские медицинские практики, как свидетельствует исторический опыт, достаточно действенные технологии, например [71].

Важно обратить внимание на то, что посевы Cannabis sativa L. - особые сгущения жизни, используемые наркоманами, экологически зависимы. Короткий день, искусственное освещение, структурные повреждения - причина обратимого превращения пола конопли. При этом осуществляющийся в ценопопуляциях конопли негативный отбор приводит к изменению у этого растения соотношения полов [129].

В связи с панглобальным распространением как наркотизма и токсикомании, так и алкоголизма и никотиномании, все большее и большее значение приобретают обоснование, разработка и юридическая, криминалистическая и наиболее ответственная - клиническая апробация целевых стандартов на дифференциальную диагностику, лечение и послелечебную социальную реабилитацию наркоманов, токсикоманов, алкоголиков и никотиноманов. Очевидно, что упомянутые стандарты окажутся востребованными даже в тех случаях, когда будет исследована и создана система, в том числе и приборная (аналитическая), предвидения, предвосхищения, предопределения и предотвращения взаимосвязанных друг с другом процессов возникновения и становления упомянутых криминальных и асоциальных явлений. Одна из таких возможностей - создание специальных имитаторов каннабиноидов, опиатов и т. д. (в том числе имитаторов амфетамина и дезаморфина).

В связи с наблюдающимся у наркоманов и иных криминальных личностей летальных исходов жизни, вызванных асоциальными склонностями, становится необходимым установить причины и забо- левания и ухода из жизни в соответствии в первую очередь с классификацией болезней и причин смерти $[177,314]$. Многим упомянутым личностям присущи лизергиновый и мескалиновый психозы, у их детей диагностически определены синдром Дауна, синдром Кляйнфельтера, синдром Марфана и иные наследственные синдромы, слабоумие - следствие гашишизма. Им самим, как и их потомкам, присущи ограниченная способность или же неспособность оценивать объективно сроки собственной жизни и риски, возникающие на протяжении жизни, в том числе и риски экологические $[256,260]$, определять приемлемые для них планы и структуру поведения [185] и т. д. Показательно, например, что по данным 1971 г. в Ленинграде синдром Дауна у новорожденных определялся в числе 1 : 912, а в Москве с 1959 по 1965 г. число новорожденных с синдромом Дауна было равно $1: 700[18,85]$. Демонстративно, далее [42], что в зависимости от дозы фенамина (как и брома) время проявления реакции больного человека может быть как укороченным, так и удлиненным, что свидетельствует о безусловной важности исследований в области близких друг другу экологической психиатрии и психоэкологии [42, 83, 269].

Актуальная проблема - реклама средствами массовой информации (в публикуемых изданиях, с помощью кинематографа, телевидения, театра) как опасности наркомании, потребления психотропных зелий, токсикомании, никотиномании, алкоголизма, сложностей избавления от них, так и лечения и возвращения к нормальной жизни [133, 326].

Реклама должна быть убедительной, постоянно привлекающей к себе внимание, рассчитанной на школьников, студентов и взрослых. Она должна свидетельствовать о реальной опасности для конкретной личности и для его близких, о неизбежности судебного наказания и о возможностях удовлетворения чувственных исканий иным путем - занятиями спортом, в том числе и атлетизмом, а также хореографией, скалолазанием, водным и пешеходным туризмом, ориентированием в лесной и иной обстановке и т. д.

Проблема экологической зависимости наркомании как вопиющего по своим последствиям социального зла с точки зрения любого морально здорового и специально целенаправленно неангажированного человека - безусловно, одна из основополагающих. Для того чтобы по возможности наиболее адекватно смыслу определить значение этой проблемы, необходимо установить сущность термина «экология» как пограничного и междисциплинарного, соответствующего особой науке. Классическим определением экологии признано определение, формулированное Эрнстом Геккелем, который полагал, что «под экологией мы подразумеваем общую науку об отношениях организма к окружающей среде, куда мы относим все “условия существования” в широком смысле этого слова. Они частично органической, частично неорганической природы; поскольку оказывают влияние на форму организмов, то тем самым они заставляют их приспосабливаться к этим условиям. К неорганическим условиям существования, к которым должны приспосабливаться все организмы, относятся в первую очередь физические и химические особенности его местообитания, климат (свет, тепло, влажность и электрические свойства атмосферы), неорганическая пища, состав воды, почвы и т. Д. Под органическими 
условиями существования мы подразумеваем общее отношение организма к другим организмам, с которыми он вступает в контакт и среди которых большинство способствует его пользе или вредит. Каждый организм имеет среди остальных своих друзей и врагов, таких, которые способствуют его существованию, и тех, кто ему вредят. Организмы, которые служат пищей остальным или паразитируют в них, во всяком случае относятся к данной категории органических условий существования. Сколь крайне важны все эти приспособительные отношения для формообразования организмов или как влияют на борьбу за существование, условия жизни, особенно органические и в меньшей мере неорганические, все это нам может объяснить теория отбора. Однако, несмотря на исключительно важное значение этих условий, должное научное исследование их не было произведено» [294, 329].

Следует отметить, что в своей академической лекции «О ходе развития и задачах зоологии», опубликованной в 1869 г., Эрнст Геккель выступает против тенденции именовать экологию биологией [294, c. 18].

В.И. Вернадский, используя термин «экология», ни в одном из сочинений не предложил его определение, причем в основном он писал не об общей экологии, а упоминал лишь экологию растений [58]. Вместе с тем, анализ опубликованного В,И. Вернадским, в том числе и его высказывания, дает основание полагать, что В.И. Вернадский рассматривал экологию как обобщающую науку о взаимоотношениях организмов друг с другом и с окружающей их природной средой.

Разнообразие опубликованных определений экологии весьма велико. Их существует более ста. Предложено определение экологии как науки о законах, отражающих:

1) сущность взаимоотношения организмов продуцентов, консументов и редуцентов друг с другом, с атмосферой, гидросферой, пелосферой, педосферой, литосферой и искусственно созданными материалами, свидетельствующее об отличиях экологии как науки и наук об окружающей среде - географии, геологии, климатологии, гидрологии, океанологии, педологии и т. д.;

2) процесс возникновения и функционирования экологических систем (основывающейся на содержании системологии, на системном подходе и системном анализе);

3) определяющих взаимную зависимость и взаимную обусловленность в пространстве биосферы как сверхбольшой и сверхсложной экосистемы биогеохимических и биогеофизических циклов;

4) обмен потоками массы, энергии и информации между организмами (живым веществом) и между организмами и веществом Земли как планеты, возникшим и возникающим в ее геологической истории вне зависимости от деятельности организмов, в зависимости от их деятельности или созданным и создаваемым человеком с утилитарными целями [258, 264].

Последнее из предложенных определений экологии наиболее обобщающее и отражающее представление о том, каким требованиям должны удовлетворять законы науки, учитывая, естественно, что в основе любых из них должны быть системный подход и системный анализ. Каждый из законов нау- ки, следовательно и законов экологии, должен быть справедлив (естественно с определенными допущениями) и должен выполняться в соответствующих для него пространстве и времени [59]. Такое требование свидетельствует о том, что как экологическая безопасность и характеристики жизни человека. так и экологическая опасность и создаваемые инженерно-мелиоративные системы экологической защиты, служащие цели охраны человека, общества, результатов их труда и органы природы, обязаны быть действенны в установленные сроки и в установленном месте [258, 259, 264]. Это условие удовлетворяет интересам и приоритетам России, включая интересы и приоритеты экологические.

\section{Озеленение, фитотоксины, микотоксины, зоотоксины, биотерапия онкологических болезней}

Одно из наиболее действенных составляющих системы экологической защиты - целенаправленное озеленение, стратегии которого, определяющие и выбор видов растений, их культиваров и сочетание выбранного - условие достижения эффективности [257]. Уместно подчеркнуть, что наркотически активные, психотропные и любые ядовитые растения, а также гименомицеты, - элементы той или иной местной флоры и грибной биоты (в том числе и специально выращиваемые, в частности, и для криминальных целей) и, тем самым, составляющие растительного и грибного покровов $[57,81,146]$.

В связи с этим актуальная проблема - определение количественного содержания в растениях и в грибах, в частности, в Amanita phalloides (Fr.), Amanita virosa (Fr.), Amanita muscaria (L.), Amanita pantherina (D.C.), Amanita mappa (Batsch.) и Amanita porphyria (A. et S.), синтезируемых, накапливаемых и опасных для человека, а также и для животных химических соединений и их комплексов - каннабиноидов, опиатов, ядовитых веществ в целом (число видов и культиваров ядовитых растений в флоре России варьирует у разных исследователей от 170 до 690, число видов ядовитых грибов, в первую очередь высших, в Европейской части страны - семь, число видов низших грибов, содержащих ядовитые вещества, во многие десятки раз больше) $[13,57,60,71,81,97,146]$.

Основные микотоксикозы: стахиботриотоксикоз, фузариотоксикозы, лейкоэнцефаломаляция, сафраминотоксикоз, афлатоксикоз, охратоксикоз, дендродохиотоксикоз, миротециотоксикоз, питомикотоксикоз, клавицепстоксикозы, треморгенотоксикоз, рубратоксикоз, патулинотоксикоз, люпиноз, диплодиоз, фоматоксикоз.

Характеристики наиболее распространенных из этих митоксикозов следующие. Стахиботриотоксикоз (продуцент Stachybotrys alternans Bonord.) стахиботриотоксины сходны с сердечными ядами растительного и животного происхождения. Их действующее начало - роридин Е, сатратоксин $\mathrm{H}$, сатратоксин Д, сатратоксин C, сатратоксин F, веррукарин А.

Фузариотоксикозы (продуцент Fusarium spp.) трихотецены, зараленон, монилиформин, и т. д. (наиболее распространенные Т-2 токсин, НТ-2 токсин, неосоланиол, диацетоксискирпенол, ниваленол, фузаренон-X, дезоксиниваленол и монилиформин (продуценты Fusarium moniliforme J. Sheld., Fusarium ox- 
ysporum Schlecht. C., Gibberella acuminata Wollenw. Синоним Fusarium acuminatum Ellis et Everh.)), а также фузариоцин А, фузариоцин С, бутенолид.

Афлатоксикоз - действующее начало афлатоксины (продуценты Aspergillus flavus, Link, Aspergillus parasiticus Spear) - экзотоксины и эндотоксины - производные дегидрофурана. Наиболее распространены и опасны афлатоксин В1, афлатоксин В2, афлатоксин $\mathrm{J}_{1}$, афлатоксин $\mathrm{J}_{2}$.

Миротециотоксикоз - действующее начало миротециотоксины веррукарин А и роридин А (продуценты Myrothecium verrucaria (Abb. et Schwein.) Ditmar, Myrothecium roridum Tode, Xepicula leucotricha (Peck) Nag Raj (синоним Myrothecium leucotrichum (Peck) M.C. Tulloch.).

Эрготоксикоз - действующее начало эрготоксины (продуценты виды спорыньи Claviceps purpurea (Fr,) Tul. и Claviceps paspali F. Stevens et J.G. Hall.), синтезирующие алкалоиды на основе лизергиновой и изолизергиновой кислот: эргин, эргинин, эргокорнин, эргокорнинин, эргокристин, эргокристинин, $\alpha$-эргокриптины, $\beta$-эргокриптины, эргометрин, эргометринин, эргосекалин, эргосекалинин, эргозин, эргозинин, эргостин, эргостинин, эрготамин, эрготаминин, изолизергиновую кислоту, лизергид и клавиновые алкалоиды: агроклавин, секаклавин (ханоклавин-I), ханоклавин-II, костаклавин, циклоклавин, дигидролозергол-I, элимоклавин, элимоклавин-О- $\beta$ Д-фруктозид, фестуклавин, фумигаклавин А и В, изоханоклавин-I, изолизергол, изоленниклавин, пенниклавин, изосетоклавин, лизерген, лизергин, лизергол, сетоклавин, норсетоклавин.

Рубратоксикоз - действующее начало рубратоксины: рубратоксин А, рубратоксин В, обладающие тератогенным, мутагенным и гепатотоксическим действием (продуценты Talaromyces ruber (Stoll) N. Yilmaz, Houbtaken, Frisvad et Samson (синоним Penicillium rubrum Stoll) и Talaromyces purpureus (E. Müll. et Pacha-Aue) Stolk et Samson (синоним Penicillium purpureum Stolk et Samson)) [220].

Ядовитые растения являются продуцентами более 160 ядовитых химических соединений - представителей разных химических классов, а также 15 эфирных масел. Как известно, популяции растений, а также грибов существующих видов в зависимости от условий произрастания различаются по содержанию действующих веществ, и у них формируются внутривидовые отличия - хемотипы [296, 297].

Актуальная проблема при решении столь серьезной международной проблемы, как уменьшение опасности наркомании, - создание безгашишной конопли, которое осуществляется в настоящее время с использованием генетических технологий [95]. Нельзя не упомянуть, что, как на эту возможность обращалось внимание и ранее [252], уменьшение и целенаправленное увеличение содержания фитогенных наркотиков в растениях-продуцентах может быть достигнуто с помощью технологий генетической инженерии - генетического модифицирования [106, 197$].$ Следует отметить вместе с тем, что уже существуют сорта Cannabis sativa L., содержание каннабиноидов в которых уменьшено, хотя биомасса их продуцентов и может быть выращена в условиях in vitro практически до любого количества $[111,318]$.

Всесторонне исследуя коноплю, крайне существенно обратить внимание на следующее. Биомасса конопли, ее вегетативных и репродуктивных органов - источник действенных наркотических средств. Несмотря на исследование конопли на протяжении многих столетий, необходимая система представлений о ней все еще отсутствует. Вместе с тем, такая система представлений - обязательное условие для обоснования и осуществления мероприятий по предотвращению распространения изготавливаемых из конопли наркотических средств.

Важнейшие из вопросов, требующих специального анализа и решения, следующие:

1) анализ системы рода конопля - Cannabis L.(в coответствии с опубликованными данными (Н.И. Вавилов, И.А. Сизов, О. Heuser, Т.Я. Серебрякова, Д.Э. Янишевский, И.Л. Никифоров) в состав рода Сannabis L. включались:

Cannabis sativa L.

var. culta var. spontanea Serebr. var. praecox Serebr.

Cannabis indica Lam. var. afganica Vav. var. kafiristanica Vav. var. transcaucasica

Cannabis chinensis Delile

Cannabis gigantea Horst.

Cannabis americana ex Wehmer

Cannabis x intensita Soják subsp. x intensita (Soják) Soják

Cannabis foetens Gilib.

Cannabis ruderalis Janisch. раса мелкосемянная, раса крупносемянная

Cannabis macrosperma Stokes,

причем видовая и подвидовая самостоятельность отдельных таксонов требует подтверждения, в особенности учитывая выраженную пластичность и увеличение морфологического разнообразия конопли при разных условиях произрастания; подтверждение такой необходимости - указания на то, что

C. sativa L. var. cilta $=$ C. indica Lam. var. culta

C. sativa L. $=$ C. foetens Gilib.

C. $\mathrm{x}$ intensita Soják. $=$ C. sativa L. subsp. $\mathrm{x}$ intensita (Soják) Soják.

C. ruderalis Janisch $=$ C. sativa L. subsp. spontanea Serebr.

C. indica Lam. $=$ C. sativa L.

C. indica Lam. = C. macrosperma Stokes;

установление действительного состава рода требует одновременных с морфологическим анализом также цитогенетического, хемотакономического и молекулярно-генетического анализов, без учета выводов которых нереально и определение самостоятельности и распространения внутривидовых популяций, создающих наркотический риск);

2) анализ молекулярного состава наркотического вещества (молекулярный состав биомассы вегетативных и репродуктивных органов конопли включает в себя биологически активные:

тетрагидроканнабинолы,

$\Delta$-9-тетригидроканнабинол,

никотин,

никотиновую кислоту (= ниацин),

каннабигерол,

кннабигероловую кислоту,

каннабидиол, 
каннабидиоловую кислоту,

каннабидихромен,

каннабиноиды с структурой, окончательно не установленной,

пиперидин,

$\beta=$ резерпиновой кислоты дериваты,

тригонеллин,

(c)-5-изопропенил-2-метил-2-циклогексенон (= карвен),

евгенол,

$\mathrm{B}_{2}, \mathrm{~K}_{1}$ и иные витамины, причем из этих соединений

четыре ( $\Delta$-9-тетрагидроканнабинол и другие тетрагидроканнабинолы, каннабидиол, никотин) - наркотики, два (каннабиноиды, евгенол) - анестетики, одно (каннабидиол) - анальгетик, несколько (каннабидихромен, дериваты $\beta=$ резерпиновой кислоты) характеризуются седативным действием, одно (карвен) - стимулятор активности центральной нервной системы, и т. д., что свидетельствует о множественности химических соединений, оказывающих влияние на проявление у конопли наркотического эффекта);

3) установление сущности взаимодействия индивидуальных биологически активных химических соединений, образующихся в конопле, в проявлении наркотического эффекта (учитывая синтез в конопле биологически активных соединений, способных одновременно оказывать различные воздействия, необходимо понимание их синергизма, антагонизма, взаимного потенцирования, проявления кумуляции и закона Арндта-Шульца, и т. д. (свидетельство важности отмеченного - установление того, что каннабиноиды - анестетики, гипотензивные противоэпилептики и т. Д., $\Delta$-9-тетрагидроканнабинол - наркотик и антигистаминный эффектор, каннабидиол - наркотик и анальгетик, и т. д.));

4) установление значения в накоплении наркотически активных соединений и предшественников их синтеза календарных сроков созревания конопли на протяжении вегетационного периода (так как виды и культивары конопли различаются по срокам созревания);

5) установление динамики накопления наркотически активных соединений и предшественников их синтеза в конопле популяций поскони и популяций матерки в связи с их отличием по срокам начала цветения;

6) установление динамики накопления в конопле наркотически активных соединений и предшественников их синтеза до достижения ею биологической зрелости и начала уборки на зеленец;

7) установление количественного и качественного состава наркотически активных соединений и предшественников их синтеза у конопли, принадлежащей популяциям поскони и популяциям матерки в целом, что важно и в связи с реальностью переопределения пола у конопли (в частности, при гибридизации);

8) установление отличий в динамике накопления наркотически активных соединений и предшественников их синтеза в конопле, различающейся по половой принадлежности (в матерке, в матерке однодомной, в матерке маскулинизированной, в матерке феминизированной, в поскони феминизированной однодомной, в поскони маскулинизированной однодомной, в гермафродитных растениях);
9) установление отличий в динамике накопления наркотически активных соединений и предшественников их синтеза в конопле местных сортов самостоятельных так называемых кряжей (пример которых - сорта «Каменец-Подольская», «Старооскольская», «Трубческая», «Новгород-Северская», «Золотоношская». «Проскуровская») и в конопле географических типов (число основных из которых шестнадцать);

10) установление зависимости динамики накопления в конопле наркотически активных соединений и предшественников их синтеза от использования азотных удобрений (определяющих в значительной мере сроки бутонизации и завершения цветения поскони), калийных удобрений (определяющих в значительной мере сроки цветения и завершения цветения поскони), фосфорных удобрений (определяющих в значительной мере сроки формирования и созревания семян матерки);

11) установление зависимости динамики накопления в конопле наркотически активных соединений и предшественников их синтеза при использовании в ее селекции эффектов гетерозиса, полиплоидии (в частности, тетраплоидии) и при появлении мужской стерильности;

12) установление реальности и биосинтетических механизмов изменения количественной и качественной динамики содержания наркотически активных соединений и предшественников их синтеза в конопле новых сортов после третьего поколения (третьей репродукции);

13) установление закономерностей влияния на динамику накопления наркотически активных соединений и предшественников их синтеза:

- опыления конопли, содержащей наркотически активные соединения, коноплей, не содержащей их, и коноплей с минимальных их содержанием (с учетом содержания предшественников их синтеза);

- опыления конопли, не содержащей наркотически активные соединения или с минимальным их содержанием (с учетом содержания предшественников их синтеза), коноплей, содержащей наркотически активные соединения;

14) установление целесообразности и действенности осуществления селекционного процесса при создании конопли новых и совершенствовании существующих сортов с целью уменьшения содержания наркотически активных соединений технологий

химического мутагенеза,

физического мутагенеза,

импульсного освещения,

ультрафиолетового облучения,

молекулярной генетики (генетического модифицирования);

$15)$ установление критических сроков синтеза и накопления в конопле наркотически активных соединений и возможностей блокирования синтеза этих соединений в критические сроки воздействием на коноплю антиметаболитами, химическими регуляторами роста, химическими стерилизаторами и т. д. с использованием микроаэрозольного и ультрамикроаэрозольного опрыскиваний;

16) установление наркотической активности экстрактивных комплексов, образующихся в конопле, с использованием скрининговых технологий биотестирования, биосенсометрии и хемосенсометрии; 
17) установление динамики количественного и качественного содержания наркотически активных соединений в конопле на протяжении ее онтогенеза с использованием

методики химического анализа газофазных и жидкофазных выделений листьев,

методики жидкокристаллической идентификации;

$18)$ установление возможности регуляции численности конопли в ее посевах и при естественном размножении с использованием биологических технологий (в частности, технологий использования монофагов, например, подобных по эффективности Pyrausta nubilalis Hb., Psylliodes attenuata Koch., и т. д., которые могут быть выведены с использованием специальных генетических методик).

Осуществление изложенного оправдано, так как ожидаемые результаты должны способствовать разработке биологически обоснованной стратегии и оперативных частных тактик уменьшения пространств распространения конопли, способствующей наркомании, и созданию технологии растениеводства конопли, экономически необходимой для изготовлений изделий, производимых предприятиями легкой промышленности.

Оправдано обратить внимание на то, что продуцентами наркотических и психотропных химических веществ являются не только уже упомянутые Cannabis sativa L. и некоторые иные представители рода Cannabis, Papaver somniferum L. и некоторые иные представители рода Papaver, Lophophora williamsii Y.M. Coult., Erythroxylum coca Lam., Catha edulis Forssk ex Endl., Piper betle L., Tabora iboga Baiil, Psilocybe Mexicana Heim, но и Nicotiana tabacum L., Nicotiana rustica L., Theobroma cacao L., Coffea arabica L., Psilocybe cubensis (Earle) Singer, Panaeolus papilionaceus (Bull. ex Fries) Quélet, Stropharia inuleta (Fries) Quélet, из высших грибов Amanita spp., но также и цианеи и зеленые водоросли, следует привлечь внимание к экспериментально установленному явлению [79] - действенной задержке роста высших растений под влиянием никотина, кокаина, бруцина (его гидрохлорида), стрихнина (нитрата) и гидрохлорида морфина. Необходимо упомянуть, что химическое соединение псилоцибин, продуцируемое представителями рода Psilocybe, принадлежит по своей биологической активности к категории психомиметиков, способствующих созданию психомиметических и наркомиметических препаративных средств, существенных для ограничения распространения наркотизма и токсикомании [24]. Такое ограничение необходимо наркоманам, потребляющим наркотики постоянно, в связи с возникновением у них зависимости и образованием церебральных лимфом, лечение которых - сложная и многоаспектная клиническая проблема [292]. Уместно все же отметить и полезное значение опиатов, кодеина и морфина несмотря и на привыкание к ним, так как их прием по рецепту врача - условие обезболивания больных раком [196].

Продуцентами наркотических и психоактивных веществ помимо растений и грибов являются также наземные и водные (океанические и морские) беспозвоночные и позвоночные животные - из мира беспозвоночных некоторые виды Protozoa, Porifera, Cnidaria, Mollusca, Arthropoda, из мира позвоночных рыбы, амфибии, рептилии и млекопитающие [27, 223].

Оправдано отметить, что с биологически активными веществами, продуцируемыми некоторыми простейшими, связаны события, обсуждавшиеся правительствами СССР, США и многих иных стран [99]. Из организма паразитического простейшего Schizotrypanum cruzi (Chagas) было выделено биологически активное вещество с противораковой активностью, положившее начало биотерапии рака и названное по виду организма - продуцента круцином $[132,134,227]$.

Основа клинического использования круцина сведения о том, что при болезни чагаса число заболевших раком оказывается меньшим, чем обычно. Обсуждая проблему биотерапии рака с использованием паразитического жгутиконосца Schizotrypanum cruzi (Chagas) - продуцента круцина, необходимо отметить, что болезнь Чагаса, известная в Южной Америке, - следствие внесения в кровь губ спящего человека испражнений так называемых поцелуйных клопов - представителей семейства Triatomidae. При расчесывании губ и при зуде в них, возникающем после укола клопами, в губы попадает и Schizotrypanum cruzi (Chagas) - обитатель органов пищеварительнотранспортного конвейера клопа [125].

Следует отметить, что применение круцина не единственная возможность биотерапии рака. Вторая возможность биотерапии, клинически анализируемое использование для лечения больных раком онкотропных энтеровирусов - энтеровируса Коксаки B-5 и ECHO-7, характеризующихся, как экспериментально установлено на модели перевиваемой ангиосаркомы, онкотропностью, онколитическими свойствами, способностью вызывать регрессию опухолей $[130,205]$.

Как продуценты нейротоксичных психотропных веществ хорошо известны пауки - тарантул (Lycosa singoriensis (Laxmann)) и каракурт (Latrodectus tridecemguttatus (Rossi)), причем целесообразно отметить, что все пауки при поражении выделяют нейротоксические соединения, обладающие выраженной психотропной активностью $[116,172,290]$. В особенности опасны представители семейств Aviculariidae (подотряд Mygalomorphae), Dysderidae, Agelenidae, Segestridae, Eresidae, Lycosidae, Theridiidae, Argiopidae, Scytoidae, Heteropidae, Attidae, Ctenidae, Clubonidae подотряд Arachnomorphae [212, 213].

Все более известным становится жабий яд - активное психотропное вещество буфотонин [108]. Зоотоксинология - наука, пограничная между зоологией и токсикологией, возникшая и оформившаяся в XX в., располагает множеством фактических сведений о наркотических и психотропных веществах, содержащихся в выделениях беспозвоночных и позвоночных животных, образуемых ими как при защите от нападения, так и при нападении.

Психоактивные соединения выделяют при поражении многие беспозвоночные. их примеры - аргиопин, сакситоксин, нейротоксин актиний, коралловых полипов рода Palithoa - политоксин (одно из самых действенных природных ядовитых веществ), нереистоксин - продукт Lumbriconereis heteropoda, токсины скорпионов, токсины Myriapoda, токсины жалящих перепончатокрылых - пчел и ос, пример последних - шершень Vespa crabro L. [27, 32, 64, 78, 128, 162, 179-183, 207, 208, 211, 274]. В настоящее время привлекают к себе внимание достаточно активные вещества с действенными психотропными и раздражающими свойствами - продукты анальных желез 
представителей семейств хищных млекопитающих Viverridae и Mustelidae, пример которых цибетин пахучий секрет представителей видов рода Viverra, специально вылавливаемых в Индии, Китае, Непале, на Филиппинах и в странах Азии с целью еженедельного получения 3-4 граммов пахучего секрета. В Индии, Шри-Ланка, Южном Китае и на Филиппинских островах содержат и представителей рода Viverricula, секрет анальных желез которых добавляют к табаку для придания ему специфического запаха. Развитыми анальными железами характеризуются особи родов Paguma и Cynogale. У Cynogale, как и у представителей рода Galidia, секрет с сильным запахом выделяется кожными железами, находящимися около половых органов. Самки особей рода $\mathrm{Ga}-$ lidictis продуцируют секрет кожными железами, pacположенными у мочеполового отверстия. У особей родов Galidia и Cryptoprocta пахучий секрет выделяется анальными и пресакральными железами. У особей рода Hemigalus анальные железы маленькие, а у особей родов Fossa и Eupleres анальные железы вообще отсутствуют. Скунсы - представители семейства Mustelidae, хорошо известны сильным и даже отвратительным запахом хорошо развитых анальных желез. Представители родов Memphitis, Pteronura и Spilogale способны выбрасывать секрет на некоторое расстояние, и при попадании в глаза он вызывает сильное жжение [272]

Следует отметить, что воздействие ядов животных по своей направленности на нервную систему и психическое состояние человека вполне сопоставимо с воздействием наркотиков растительного происхождения. Эти яды воздействуют как психостимуляторы и нейролептики, умерщвляя при частых нападениях жертву [1, 32, 64, 78, 128, 162, 179-183, 207-211, 276, 279].

Анализ экологической зависимости наркомании и пользования психотропными средствами должен основываться на содержании экологии как междисциплинарной науки и, следовательно, во-первых, отразить соотношение в природе конкретных территории и акватории видов продуцентов, консументов и редуцентов (то есть прежде всего флористический и фаунистический составы биоты и состав микобиоты), а также своеобразие занимаемого организмами географического пространства; во-вторых, дифференциацию в этом пространстве экологических систем различного размерного ранга; в-третьих, важнейшие отличия в обсуждаемом географическом пространстве основных биогеохимических и биогеофизических циклов (в особенности существенных, если они включают в себя перенос радионуклидов), и, в-четвертых, главные сведения о потоках вещества, энергии и информации, осуществляющихся между организмами, веществом Земли - горными породами, грунтами, почвами, донными осадками, водной и воздушной средами и созданной человеком продукцией. Очевидно, что при анализе, приводимом с использованием упомянутых данных, должны быть учтены природная очаговость трансмиссивных болезней, если, безусловно, в видовом составе беспозвоночных и позвоночных животных есть виды переносчики и виды - окончательные и промежуточные хозяева [214-216].

Естественно, что для ожидаемого анализа целесообразно установить по возможности наибольшее количество объективных показателей, включая и показатели, уточнение которых связана с исследовательскими трудностями.

К каким трудновыявляемым и труднооцениваемым показателям принадлежат показатели числа существующих хемотипов - организмов с видовыми и внутривидовыми отличиями по химическому составу, характерными для животных и, в особенности, для растений $[112,296,297]$; климатотипы как по химическому составу, так и по морфологическим признакам, в том числе количественным, число и разнообразие генетически модифицированных организмов различной систематической принадлежности, постоянно изменяющие биомассу на многих территориях и во многих акваториях; естественно возникающие при изменении пространства обитания экотипы (экоморфы) и организмы с отличиями по сезонным циклам и ритмам жизнедеятельности (феноритмам), причем любые из упомянутых отличий организмов должны характеризоваться определенной приуроченностью к пространству занимаемого ими ареала.

Важно, чтобы определенная приуроченность к ареалу (у больных - нозоареалу) была выяснена при никотиновой наркомании, при кофеиномании, всех формах наркотизма и потребления психотропных средств [41, 275].

Безусловное осложнение для рассматриваемого анализа - миграции как человека, так и беспозвоночных и позвоночных животных, появление вселенцев, во многих случаях оказывающих действенное влияние на виды аборигены, что во многих отношениях опасно, если вселенцы - хищники и паразиты.

Необходимо отметить, что анализ наркомании и токсикомании как асоциальных явлений и оценка их экологической зависимости должны характеризоваться безусловной целостностью. У этих анализа и оценки должны быть учитывающие присущую им чрезвычайную многоаспектность и сложность определенные последовательность и преемственность в согласованных системных решениях и действиях.

Очевидно, что первостепенное значение для любой личности, в том числе и личности наркомана, токсикомана, никотиномана и алкоголика, имеет выздоровление с последующей социальной реабилитацией, восстановление нервной системы и психической адекватности, сохранение семьи, возможностей продолжения рода и воспитания потомков, что требует выполнения определенных фармацевтических, фармакологических, терапевтических, социальных и юридических требований.

Следует отметить, что несмотря на государственные запреты противоправных действий все еще до недавнего времени сохранилось учреждение, способствующее никотиномании, - Институт табака, махорки и табачных изделий. Присущие табаку и махорке запахи оказывают, как известно, привлекающее действие на никотиноманов и курильщиков. Принципиальны в связи с изложенным учет фармакологических, фармакогенетических и токсикологических закономерностей и возможности экспериментального моделирования, использующего, в частности, и ветеринарную токсикологию [29, 40, $80,166,174,228,280]$. Целесообразно отметить и абсолютную необходимость учета сведений о лекарственных препаратах с искусственно конструируемой молекулярной структурой [69], которые непременно должны привлечь к себе внимание в 
связи с распространяющимися угрозами наркомании, возникающими на потенциально опасных объектах [124].

Экологическая зависимость - зависимость от влияния собственно экологических факторов биологического, физического, химического, географического и социального происхождения. Наркотизм, токсикомания, склонность к никотину, алкоголизм, фактически любые нежелательные для человека и противоправные пристрастия в той или иной мере зависимы от действенности экологических факторов и от их сочетания. Температура, влажность и водообеспеченность, атмосферное давление, активность электромагнитных полей, освещенность, солнечная инсоляция, вибрационное непостоянство места нахождения (пола, поверхности земли, водной среды и т. д.) оказывают непосредственное влияние на действия наркоманов и иных противоправных личностей, на саму возможность введения наркотика, вдыхания ядовитого вещества, потребление алкоголя, курения табака и т. д.

Изложенное - основание оценивать рассматриваемую социальную аномалию как особое экологическое преступление, представляющее собой угрозу государственной безопасности Российской Федерации $[282,283]$.

Самостоятельная проблема - сравнительная оценка высших и низших растений и низших грибов продуцентов опасных для человека и животных атропина, бруцина, героина, камфары, кофеина, кодеина, кокаина, кураре, морфина, никотина, опиатов, папаверина, скополамина, тебаина, теобромина, стрихнина, строфантина, эфедрина и дезоксиэфедрина, представителей цианей из родов Anabaena, Aphanizomenon, Microcystis и Nodularia, возбудителей так называемого цветения воды, смертельно опасного для человека юксовско-сартланской или так называемой Гаффской болезни [171], а также низших грибов - спорыньи Claviceps purpurea (Fr. Icl. (бича Европы - гангренозного эрготизма или «антонова огня»), фузарий (причины так называемого «пьяного хлеба» и т. д.), патогенных для человека [36, 37, 52, 53, 74, $104,126,171,237,245-247,273,285,289,308]$. Следует отметить, что многие из упомянутых выше алкалоидов - атропин, скополамин и т. д. - успешно исторически используются в терапевтической практике.

Сопоставимая проблема, на которую уже обращалось внимание, - сравнительная оценка ядов низших и высших беспозвоночных животных и низших позвоночных животных. Яды беспозвоночных рассмотрены выше. Яды низших позвоночных животных - прежде всего яды рыб. Наиболее патогенный из них тетраодотоксин, продуцируемый видами родов Lagocephalus spp., Sphaecoides spp., Tetraodon spp., Fuga spp. [1, 274], а также яды амфибий, в частности батрахотоксин Phyllobates. Яды позвоночных животных, находящихся в филеме позвоночных на ступени, следующей за амфибиями, - яды рептилий, прежде всего яды змей. Эти яды - преобразованная слюна, их действующее начало - белки и ферменты. Выделяются яды при укусе ядовитыми зубами. В результате действия змеиного яда происходит свертывание кровяных клеток и разрушение стенок капилляров системы микроциркуляции. Их эффект гемотоксический и геморрагический у одних видов змей и нейротоксический, вызывающий паралич сер- дечных мышц и остановку дыхания, у других видов змей. В России наиболее опасны яды змей десяти видов - кобры Naja oxiana (Eichw.) - представителя семейства аспидов Elapidae, носатой гадюки Vipera ammodytes (L.), обыкновенной гадюки Vipera berus (L.), кавказской гадюки Vipera kaznakowi Nik., гюрзы Vipera lebetina (L.), малоазиатской гадюки Vipera raddei Boett., степной гадюки Vipera ursine (Bonap.), эфы Echis carinatus (Schneid) - представителей семейства гадюк Viperidae, восточного щитомордника Agkistrodon blomhoffi (Boie) и обыкновенного щитомордника Agkistrodon halys (Pall.) - представителей семейства ямкоголовых змей семейства Crotalidae.

Весьма показательно сравнение эффектов действия ядовитых начал растительного, животного и грибного происхождения, учитывая их химизм, концентрацию, проницаемость, распространяемость по организму, растворимость в биологических жидкостях, прежде всего в крови и лимфе [27]. Экспериментально установлено, что эффект диазепинов в умеренных дозах сопоставим с действием барбитуратов, опиатов, кодеина и метадона.

Следует привлечь внимание к тому, что беспозвоночным и позвоночным животным свойствен врожденный иммунитет, основанный на антибиотических пептидах, пример которых - дефенсимы насекомых, паукообразных (в том числе скорпионов), мечехвостов и моллюсков, амебопоры протистов, ускропины и магейнины, исполняющие функцию медиаторов эндокринноимунных взаимодействий [135].

Оценивая такое психотропное явление, как никотиномания, следует отметить, что у курящих, в особенности курящих часто, моча мутагенна [330]. Мутагенность мочи курящих аналитически экспериментально выявлена еще в конце двадцатого столетия. Клинические выводы для судьбы курящих и судьбы их потомков осознать не трудно.

Изложенное - свидетельство многоаспектности рассматриваемой социальной аномалии. Ликвидация этой аномалии может быть достигнута лишь на основе повышения уровня и качества жизни, духовности, постоянного приобщения к культуре и использования достижений цивилизации и ее основы - науки.

\section{Заключение}

Пути и условия преодоления опаснейшего для каждого человека и человечества в целом всемирного зла - наркомании, потреблении психотропных зелий, алкоголизма, токсикомании, никотиномании известны, проверены и подтверждены судьбой многих людей разных пола и возраста.

Содержание рекомендаций по преодолению рассматриваемого зла следующие.

1. Повышение уровня и улучшение качества жизни.

2. Изменение в благоприятном направлении индивидуальных особенностей жизни - их образа, уклада и стиля.

3. Улучшение состояния окружающей среды.

4. Постоянное приобщение к знаниям, их расширение и углубление.

5. Замена чувственных исканий, находимых в аномальных склонностях и привычках, в приобщении к спорту, к искусству, к изобретательской деятельности, к литературному творчеству, к рукотворному труду - вышиванию, обработке металла, дерева, кости, кожи, камня и т. д. 
6. Повышение духовности.

Изложенное убеждает и свидетельствует, что преодоление рассматриваемых аномальных склонностей и пристрастий вполне возможно.

Для создания объективного и большего представления об аномальных пристрастиях важно рассмотрение многих взаимосвязанных тем, содержание некоторых из них следующее:

1. Наркомания как историческое составляющее конфессиональных и этнических традиций.

2. Антинаркотическая агитация, ее значение в ограничении распространения наркомании и возможности совершенствования.

3. Наркомания как система: реальное и нереальное в ее предотвращении с использованием общественных организаций.

4. Наркомания как феномен конфликтной философии.

5. Психоанализ и возможности его применения для предупреждения склонности к наркомании.

6. Рецидивы наркомании: условия и возможности их предупреждения.

7. Использование эффекта Кирлиан для установления склонности к наркомании и эффективности излечения

8. Возможности использования жидких кристаллов для установления меры наркотической зависимости и действенности лечения.

9. Возможности молекулярной генетики и генетической инженерии для ограничения распростра- нения растений, грибов и животных - продуцентов наркотических веществ

10. Биорегуляторы и избавление от наркотической зависимости.

11. Возможности молекулярного конструирования соединений с наркотической и антинаркотической активностью.

12. Проблема химической чистоты наркотиков и ее значение.

13. Наркомания как пандемия и как эпидемиологический фактор.

14. Наркология и сексология, гендерные характеристики, половой и возрастной преферендум.

15. Наркотики - закономерности токсикогенеза и применимость закона Арндта-Шульца.

16. Употребление наркотиков: радиационный риск.

17. Энзиматическая деструкция наркотиков и энзимотерапия наркотической зависимости.

18. Фотодеструкция наркотиков и продукты фотолиза.

19. Термолиз и пиролиз наркотиков и их продукты.

20. Наркотики как составляющие пищевой и питьевой диеты.

21. Наркотики как составляющие аллопатической и гомеопатической фармакотерапии.

22. Наркотики как оружие нелетального действия.

23. Наркозависимость и злокачественные опухоли головного и спинного мозга, включая лимфомы, и возможности нейрохирургической помощи.

24. Биологически активные добавки и наркотическая зависимость.

\section{Литература}

\section{Список русскоязычной литературы}

1. Ажгихин ИС, Шпаков ЮН, Кипиани РЕ, Гандель РВ. Морская фармация (Теория и практика нового направления в фармацевтической науке). Кишинев: Штиинца; 1982. 260 с.

2. Алекперов УК. Особенности действия антимутагенов и перспективы их практического применения. Успехи современной генетики. Сборник 8. Отв. ред. НП Дубинин. М.: Наука; 1979. с. $168-81$.

3. Александровский АЮ. Пограничные психические расстройства. Руководство для врачей. М.: Медицина; 1993. 400 с.

4. Альберт А. Избирательная токсичность. Физико-химические основы терапии. М.: Медицина; 1989а. Т. 1. 399 с.

5. Альберт А. Избирательная токсичность. Физико-химические основы терапии. М.: Медицина; 1989б. Т. 2. 428 с.

6. Анаша под окнами милиции. Материал подготовлен Г.Ф. Андросенко после беседы с капитаном милиции 3.М. Укасовой. Жизнь и безопасность. СПб.; 1998;(2-3):210-1.

7. Аничков СВ. Нейрофармакология. Руководство. Л.: Медицина; 1982. 384 с.
8. Анохина ИП. Нейрохимические механизмы психических заболеваний. М.: Медицина; 1975. $320 \mathrm{c}$.

9. Антонян ЮМ, Бородин СВ. Преступность и психические аномалии. М.: Наука; 1987. 208 с.

10. Ариас Ф. Беременность и роды высокого риска. М.: Медицина; 1989. 656 с.

11. Аристович ВЮ, Аристович ЮВ, Соколов АЮ, Торопков ВВ, Бахир ВМ, Паничева СА, Альтшуль ЭВ. Русская водка - вперед в прошлое. Жизнь и безопасность. СПб.; 1999;(3-4): 94-6.

12. Бетель, кава, кола, чат. Жевательные стимуляторы в ритуале и мифологии народов мира. Малкаевский сборник. Вып. 5. Отв. ред. и сост. МВ Станюкович. СПб.: МАЭ РАН; 2002. 247 c.

13. Астахова ВГ. Загадки ядовитых растений. М.: Лесная промышленность; 1977. 176 с.

14. Бабоян Д. Путевка в АД. М.: Международные отношения; 1974. 232 с.

15. Бабоян ЭА, Гонопольский МХ. Наркология. М.: Медицина; 1987. 336 с.

16. Багрова НД. Фактор времени в восприятии человеком. Л.: Наука; 1980. 96 с. 
17. Бадалян ЛО. Невропатология. М.: Просвещение; 1982. $350 \mathrm{c.}$

18. Бадалян ЛО, Таболин ВА, Вельтищев ЮЕ. Наследственные болезни у детей. М.: Медицина; 1971. 367 с.

19. Байкова ВГ, Брюн ЕА, Гаранский АН, Колесникова ТИ, Ясонов ОВ. Наркомания в России: состояние, тенденции, пути преодоления. Пособие для педагогов и родителей. М.: ВЛАДОС-Пресс; 2003. 352 с.

20. Бакин АА. Влияние наркотических препаратов на формирование криминальной агрессии. Теория и практика противодействия незаконному обороту наркотиков. Материалы Всероссийской научно-практической конференции 15-16 декабря 2009 г. Ч. 1. Ленинградская обл.: СЗ ИПК ФСКН России; 2010. с. 91-4.

21. Баландин РК. Наркоцивилизация. Мнимая реальность. М.: Алгоритм-Книга; Эксмо; 2003. 448 c.

22. Балицкий КП, Векслер ИГ, Винницкий ВБ, Сыромятников АВ, Шмалько ЮП. Нервная система и противоопухолевая защита. Киев: Наукова думка; 1983. 256 с.

23. Балткайс ЯЯ, Фатеев ВЯ. Взаимодействие лекарственных веществ (фармакотерапевтические аспекты). М.: Медицина; 1991. 304 с.

24. Банщиков ВМ, Столяров ГВ. Новое психомиметическое средство - псилоцибин. Психические нарушения при интоксикациях и органических поражениях головного мозга. Труды 1-го Московского медицинского института им. ИМ Сеченова. Т. XXVII. Ред. ВМ Банщиков, ВВ Русских. М.: 1-й Московский медицинский ин-т им. ИМ Сеченова; 1963. с. 21-30.

25. Баранов АА, Кучма ВР, Звездина ИВ. Табакокурение детей и подростков. Гигиенические и медико-социальные проблемы и пути их решения. НИИ гигиены и охраны здоровья детей и подростков РАМН. Сер. «Социальная педиатрия». Вып. 3. М.: Литерра; 2007. 216 с.

26. Баранов ВС, Баранова ЕВ, Иващенко ГЕ, Асеев ТВ. Геном человека и гены «предрасположенности». Введение в предиктивную медицину. СПб.: Интермедика; 1999. 272 с.

27. Барбье М. Введение в химическую экологию. М.: Мир; 1978. 229 с.

28. Барковская ЕВ, Павлов ДВ. Наркоситуация: проблемы контроля и мониторинга. Теория и практика противодействия незаконному обороту наркотиков. Материалы Всероссийской научно-практической конференции 1516 декабря 2009 г. Ч. 2. Ленинградская обл.: СЗ ИПК ФСКН России; 2010. с. 19-23.

29. Барлоу Р. Введение в химическую фармакологию. М.: Изд-во иностранной литературы; 1959. $463 \mathrm{c}$.

30. Беленький БГ. Высокоэффективный капиллярный электрофорез. СПб.: Наука; 2009. $320 \mathrm{c.}$

31. Отец Сергий Бельков. Взаимодействие Русской Православной Церкви и Федеральной службы Российской Федерации по контролю за оборотом наркотических средств и психотропных веществ в сфере снижения спроса на наркотики как одно из приоритетных на- правлений антинаркотической политики. Деятельность правоохранительных органов и специальных служб в сфере противодействия незаконному обороту наркотиков: вопросы организации и координации, взаимодействия и международного сотрудничества. Материалы Всероссийской научно-практической конференции 15-16 декабря 2010 г. Ч. 1. Государственная политика, взаимодействие органов власти, общественно-государственное партнерство и международное сотрудничество в сфере противодействия незаконному обороту наркотиков. Ленинградская обл.: С3 ИПК ФСКН России; 2011. с. 8-11.

32. Бердыева ФТ. К патогенезу интоксикации ядами среднеазиатских змей гюрзы и кобры. Ашхабад: Ылым; 1972. 142 с.

33. Бернштейн ЛМ. Онкоэндокринология курения. СПб.: Наука, 1995. 127 с.

34. Бехтель ЭЕ Донозологические формы злоупотребления алкоголем. М.: Медицина; 1986. $272 \mathrm{c}$.

35. Бил Дж, Ноулз Дж. Внеядерная наследственность. М.: Мир; 1981. 168 с.

36. Билай ВИ. Биологически активные вещества микроскопических грибов и их применение. Киев: Наукова думка; 1965. 267 с.

37. Билай ВИ. Микроскопические грибы продуценты антибиотиков. Киев: Изд-во АН Укр. ССР; 1961. 183 с.

38. Биогеохимические циклы в биосфере. Материалы VII Пленума СКОПЕ, Москва, 1522 ноября, 1974. Гл. ред. ВА Ковда. Отв. научн. ред. АГ Назаров. М.: Наука; 1976. 356 с.

39. Биохимия психозов. Материалы симпозиума по химическим концепциям психоза II Международного психиатрического конгресса в Цюрихе (Швейцария) 1-7 сентября 1957 г. Ред. ДД Федотов. М.: Медгиз; 1963. 423 с.

40. Бирюков ДА. Экологическая физиология нервной деятельности (некоторые вопросы биологических основ теории медицины). Л.: Медгиз; 1960. 144 с.

41. Бодров ВЕ. Никотиновая наркомания и последствия табакокурения. теория и практика противодействия незаконному обороту наркотиков. Материалы Всероссийской научно-практической конференции 15-16 декабря 2009 г. Ч. 1. Ленинградская обл.: СЗ ИПК ФСКН России; 2010. с. 95-100.

42. Бойко ЕИ. Время реакции человека. История, теория, современное состояние и практическое значение хронометрических исследований. М.: Медицина; 1964. 440 с.

43. Болезнь Дауна. Клинические и цитогенетические исследования. Ред ЕФ Давиденкова. Л.: Медицина; 1966. 202 с.

44. Борьба с потреблением «бездымного» табака. Доклад научной группы ВОЗ. Серия технических докладов. № 773. Женева: ВОЗ; 1991. 84 с.

45. Братко АА. Моделирование психики. М.: Наука; 1969. 173 с.

46. Братус ИН. Химия душистых веществ. М.: Агропромиздат; 1992. 240 с.

47. Брежнев ДД, Шмараев ГЕ. Растениеводство Австралии. М.: Колос; 1974. 351 с. 
48. Брушлинский АВ. О некоторых методах моделирования в психологии. Методологические и теоретические проблемы. Отв. ред. ЕВ Шорохова. М.: Наука; 1969. с. 246-73.

49. Бурназян ГА. Психофармакотерапия. Ереван: Айастан; 1985. 344 с.

50. Буров ЮВ, Ведерникова НН. Нейрохимия и фармакология алкоголизма. М.: Медицина; 1985. $240 \mathrm{c}$.

51. Бэбсон СГ, Бенсон РК, Пернолл МА, Бенда ГИ. Ведение беременных с повышенным риском и интенсивная терапия новорожденного. М.: Медицина; 1979. 496 с.

52. Вавилов НИ. Центры происхождения культурных растений. Труды по прикладной ботанике и селекции. Т. 16, № 2. Л.; 1926. 248 с.

53. Вавилов НИ, Букинич ДД. Земледельческий Афганистан. Труды по прикладной ботанике, генетике и селекции. Приложение 33. Л.; 1929. $610 \mathrm{c}$.

54. Ваисов СБ. Наркотическая и алкогольная зависимость. Практическое руководство для детей и подростков. СПб.: Наука и техника; 2008. 272 с.

55. Вайсман ГЯ, Ямпольская ММ. Применение ионообменных адсорбентов в фармацевтическом анализе. Киев: Госмедиздат УССР; 1959. $88 \mathrm{c}$.

56. Вальдман АВ, Бабоян ЭА, Звартау ЭЭ. Психофармакологические и медикоправовые аспекты токсикоманий. М.: Медицина; 1988. $286 \mathrm{c}$.

57. Васильков ЮП. Съедобные и ядовитые грибы средней полосы Европейской части СССР. Определитель. М.; Л.: Изд-во АН СССР; 1948. 135 с.

58. Вернадский ВИ. Живое вещество. М.: Наука; 1978. 358 с.

59. Вернадский ВИ. Размышления натуралиста. Пространство и время в неживой и живой природе. М.: Наука; 1975. 174 с.

60. Вильнер АМ. Кормовые отравления. Л.: Колос; 1974. 408 с.

61. Владимиров ВЮ. Наркотики как оружие массового поражения пролонгированного и избирательного действия. Актуальные проблемы биологии и экологии. Сборник научных трудов. Отв. ред. АВ Селиховкин. СПб.: Санкт-Петербургская Гос. Лесотехническая академия; 2011. с. 51-64.

62. Владимиров ВЮ, Каймак ЕВ. Рост использования глазных капель «Тропикамид» в качестве заменителя наркотических средств. Биосфера. 2012;(4(1)):86-9.

63. Гаспарян СА, Островерхов ГЕ, Трапезников НН. Регионарная длительная внутриартериальная химиотерапия злокачественных опухолей. М.: Медицина; 1970. 208 с.

64. Гелашвили ДБ. Нейрогуморальные механизмы стрессорного действия зоотоксинов и физиологические основы коррекции их повреждающих эффектов. Автореф. дис. ... д-ра биол. наук. Тбилиси: Ин-т физиологии им. ИС Бериашвили АН Груз. ССР; 1989. 47 с.

65. Геномика - медицине. Ред. ВИ Иванов, ЛЛ Киселев. М.: Академкнига; 2005. 392 с.
66. Генофонд и геногеография народонаселения. Т. 1. Генофонд населения России и сопредельных стран. Ред. ЮГ Рычков. СПб.: Наука; $2000.611 \mathrm{c}$.

67. Генофонд и геногеография народонаселения. Т. 2. Геногеографический атлас населения России и сопредельных стран. Ред. ЮГ Рычков. СПб.: Наука; 2003. 673 с.

68. Гиляровский ВА. Психиатрия. М.: Медгиз; 1954. 520 с.

69. Голендер ВЕ, Розенблит АБ. Вычислительные методы конструирования лекарств. Рига: Зинанте; 1978. 231 с.

70. Головкин БН. История интродукции растений в ботанических садах. М.: Изд-во МГУ; 1981. 125 с.

71. Голосницкий АК. Профилактика отравлений животных растительными ядами. М.: Колос; 1979.165 с.

72. Гончарова ОА. Народная медицина Горного Алтая. Горно-Алтайск: Юг-Сюмер-Белуха; 2005. $120 \mathrm{c}$.

73. Горчаков ВД, Сергиенко ВИ, Владимиров ВГ. Селективные гемосорбенты. М.: Медицина; 1989. 223 с.

74. Горюнова СВ, Демина НС. Водоросли продуценты токсических веществ. М.: Наука; 1974. $256 \mathrm{c.}$

75. Горяев МИ. Эфирные масла флоры СССР. Алма-Ата: Изд-во АН Казахской ССР; 1952. $380 \mathrm{c}$.

76. Горяев М, Плива И. Методы исследования эфирных масел. Алма-Ата: Изд-во АН Казахской ССР; 1962.752 с.

77. Гришин АГ. Наркотрафик - проблемы нашего времени. Деятельность правоохранительных органов и специальных служб в сфере противодействия незаконному обороту наркотиков: вопросы организации, координации, взаимодействия и международного сотрудничества. Материалы Международной научнопрактической конференции 15-16 декабря 2010 года. Часть 1. Государственная политика, взаимодействие органов власти, общественно-государственное партнерство и международное сотрудничество в сфере противодействия незаконному обороту наркотиков. Ленинградская обл.: СЗ ИППК ФСКН России; 2011. с. 27-43.

78. Грищенко ЕВ. Что нужно знать о ядовитых рыбах Таджикистана. Душанбе: Дониш; 1984. $16 \mathrm{c}$.

79. Грюммер Г. Взаимное влияние высших растений - аллелопатия. М.: Изд-во иностр. лит.; 1957. $262 \mathrm{c}$.

80. Гудман М, Морхауз Ф. Органические молекулы в действии. М.: Мир; 1977. 335 с.

81. Гусынин ИА. Токсикология ядовитых растений. М.: Гос. изд-во сельхоз. лит.; 1951. 295 с.

82. Давиденков СН. Проблема полиморфизма наследственных болезней нервной системы. Клинико-генетическое исследование. Л.: Издво Всесоюзного ин-та экспериментальной медицины; 1934. 139 с.

83. Давиденков СН. Эволюционно-генетические проблемы невропатологии. Л.: Гос. ин-т усовершенствования врачей; 1947. 382 с. 
84. Давиденкова ЕФ. Болезнь Дауна. Л.: Медицина; 1966. 202 с.

85. Давиденкова ЕФ, Либерман ИС. Клиническая генетика. Л.: Медицина; 1975. 426 с.

86. Давиташвили ЛШ. Курс палеонтологии. М.; Л.: Гос. изд-во геологич. лит.; 1949. 835 с.

87. Давиташвили ЛШ. Причины вымирания организмов. М.: Наука; 1969. 440 с.

88. Данилин АГ. LSD. Галлюциногены, психоделия и феномен зависимости. М.: Центрополиграф; 2001. 521 с.

89. Де Крюи П. Борьба с безумием. М.: Издво иностр. лит.; 1960. 230 с.

90. Демчук СД. Общество потребления, девиантное поведение и угрозы благополучию природы. Биосфера. 2012; (4(2)):217-24.

91. Демьянов НЯ, Нилов ВИ, Вильямс ВВ. Эфирные масла. Их состав и анализ. М.; Л.: Гос. химико-технологич. изд-во; 1933. 300 с.

92. Димитров С, Жмуров А, Антонов С. Диагностика отравления животных. М.: Агропромиздат; 1986. 283 с.

93. Динамика популяционных генофондов при антропогенных воздействиях. Ред. ЮП Алтухов. М.: Наука; 2004. 619 с.

94. Дмитриев МТ, Растянников ЕГ, Малышева АГ. Табачный дым. Гигиеническая оценка органических веществ в табачном дыме. Жизнь и безопасность. СПб. 1998;(2-3):452-4.

95. Драгавцев ВА, Чесноков ЮВ. Перспективы генетических экспериментов по удалению гашишности у конопли. Жизнь. Безопасность. Экология. 2009;(3-4):41-5.

96. Дрожжин АИ, Иваненков ВВ, Митягин СА, Крысанов ВП. Организация системы мониторинга и комплексного анализа наркоситуации в регионе. Деятельность правоохранительных органов и специальных служб в сфере противодействия незаконному обороту наркотиков: вопросы организации, координации, взаимодействия и международного сотрудничества. Материалы Международной научно-практической конференции 15-16 декабря 2010 г. Часть 1. Государственная политика, взаимодействие органов власти, общественногосударственное партнерство и международное сотрудничество в сфере противодействия незаконному обороту наркотиков. Ленинградская обл.: СЗ ИПК ФСКН России; 2011. c. $50-65$.

97. Дударь АК. Ядовитые растения лугов и пастбищ. М.: Россельхозиздат; 1980. 112 с.

98. Евтеев СП. Незаконный оборот наркотических средств, психотропных, сильнодействующих и ядовитых веществ. Энциклопедический словарь-справочник для оперативных и следственных подразделений. Под ред. ИИ Батыршина. Учебное пособие. 2-е изд., испр. и доп. М.: ФКУ НИЦ ФСКН России; 2015. $440 \mathrm{c.}$

99. Есаков ВД, Левина ЕС. Сталинские «суды чести»: «Дело «КР». М.: Наука; 2005. 423 с.

100. Ефремов ИА. Тафономия и геологическая летопись. Книга 1. Захоронение наземных форм в палеозое. Труды Палеонтологического ин-та АН СССР. М.; 1950. Т. XXIV. 178 с.
101. Жидкие кристаллы в медицине. Отв. ред. ОА Пятак, МВ Курик. Киев: Наукова думка; 1981.90 с.

102. Жирнов Е. Дело о девяти банках морфия. Коммерсантъ. Деньги. 2012;(39(896).01-072012):49-56.

103. Жмуров ВА. Психопатология. Часть 2. Психопатологические синдромы. Иркутск: Изд-во Иркутского ун-та; 1994. 290 с.

104. Жуковский ПМ. Культурные растения и их сородичи. Систематика, география, цитогенетика, иммунитет, экология, происхождения, использование. 3-е изд., перераб. и доп. Л.: Колос; 1971. $752 \mathrm{c.}$

105. Зазулин Г. Союз «За общество без наркотиков». Антинаркотическая политика: шведские ответы на российские вопросы. СПб.: Изд-во СПбГУ; 2008. с. 137-70.

106. Закревский ВВ. Генетически модифицированные источники пищи растительного происхождения. Практическое руководство по санитарно-эпидемиологическому надзору. СПб.: Диалект; 2006. 152 с.

107. Заугольников СД, Кочанов МM, Лойт ДО, Ставчанский ИИ. Экспрессивные методы определения токсичности и опасности химических веществ. Л.: Медицина; 1978. $184 \mathrm{c}$.

108. Захаров ВИ. Жабий яд. Кишенев: Картя молдовеняскэ; 1961. $161 \mathrm{c.}$

109. Зацепилова ТА, Пашин ЮВ. Мутагенный потенциал лекарственных средств. Успехи современной генетики. Сборник 9. Отв. ред. НП Дубинин. М.: Наука; 1980. с. 163-70.

110. Зейгарник БВ. Патопсихология. М.: Издво МГУ; 1976. 238 с.

111. Зеленина ОН. О безнаркотичности сортов конопли, внесенных в Государственный реестр селекционных достижений. Жизнь. Безопасность. Экология. СПб. 2009;(3-4):37-40.

112. Золотницкая СЯ. Лекарственные ресурсы флоры Армении. Т. 1. Ереван: изд-во АН Армянской ССР; 1958. 327 с.

113. Зюбин БИ. Фитонематоды лекарственного мака Киргизии. Фрунзе: Илим; 1969. 99 с.

114. Иваненко ЕФ. Биохимия мозга при наркозе. Л.: Медицина; 1972. 240 с.

115. Иванич Ю. Наркотики и терроризм. Паутина зла. М.: Вече; 2005. 464 с.

116. Иванов АВ. Пауки, их строение, образ жизни и значение для человека. Л.: Изд-во ЛГУ; 1965. $304 \mathrm{c.}$

117. Иванов ВП. Состояние и насущные вопросы контроля за оборотом наркотиков в РФ. Жизнь. Безопасность. Экология. СПб. 2009;(12):37-41.

118. Иванов ВП. О новой парадигме антинаркотической политики, отрицающей насилие и реализующей право на развитие. Биосфера. 2013;(5(2)):234-6.

119. Илюк РД, Крупицкий ЕМ, Торбан МН. Феноменология передозировок у потребителей опийных наркотиков. В кн.: Теория и практика противодействия незаконному обороту наркотиков. Материалы Всероссийской научно-практической конференции 15-16 декабря 2009 г. 
Ч. 1. Ленинградская обл.: СЗ ИПК ФСКН России; 2011. с. 167-8.

120. Исследования по генетике психических болезней. Доклад научной группы ВО3. Всемирная Организация Здравоохранения. Серия технических докладов. № 346. Всемирная Организация Здравоохранения. Женева (М.: Медицина); 1967. 24 с.

121. Кабанов ММ. Реабилитация психических больных. Л.: Медицина; 1985. 216 с.

122. Кабанов ММ. Шизофрения и неврозы проблема этикетирования. В кн.: Сборник научных трудов «Диагностика и реабилитация в психиатрии». Ред. ММ Кабанов, ВИ Кашкаров, БЕ Алексеев. СПб.: Психоневрологический ин-т им. ВМ Бехтерева; 1993. с. 22-30.

123. Кабановъ Н. Роль наследственности и этиологии болезней внутренних органов. Из госпитальной терапевтической клиники Императорского Московского Университета. Дис. ... д-ра медицины. М.: Типо-Литография ГИ Простакова; 1899. 545 с.

124. Каймак ЕВ. Угрозы наркотизма на критически важных и потенциально опасных объектах инфраструктуры России. Биосфера. 2012;(4(2)):225-33.

125. Калинникова ВД. Противоопухолевые свойства жгутикового простейшего Trypanosoma cruzi. Тула: Гриф ИК; 2004. 280 с.

126. Карпенко ЮА, Сиренко ЛА, Орловской ВМ, Лукина ЛФ. Токсины сине-зеленых водорослей и организм животного. Киев: Наукова думка; 1977. 251 с.

127. Карпов ЯС, Чистяков ИН. К вопросу о контроле за оборотом сильнодействующих химических веществ, не являющихся прекурсорами, лекарственными средствами и не включенными в состав пищевых или биологически активных добавок (на примере химического вещества «гамма-бутиролактона»). В кн.: Деятельность правоохранительных органов и специальных служб в сфере борьбы с незаконным оборотом наркотиков. Материалы Всероссийской научно-практической конференции 18 19 декабря 2008 г. Часть 3. Раскрытие и расследование преступлений в сфере незаконного оборота наркотиков: состояние, проблемы и перспективы. Ленинградская обл.: СЗ ИПК ФСКН России; 2009. с. 25-40.

128. Касенов К. Змеиные яды и реактивность организма. Алма-Ата: Казахстан; 1977. 104 с.

129. Квитко КВ. К генетике пола у конопли (Cannabis sativa L.). В кн.: Исследования по генетике. Ред. МЕ Лобашев. Сб. 1. Л.: Изд-во ЛГУ; 1961. с. 106-15.

130. Киселев АС, Сочнева ЗГ. Закономерности начала, течения и исходов основных психических заболеваний (статическое исследование). Рига: Зинатне; 1988. 236 с.

131. Клиническая токсикология детей и подростков. Под ред. ИВ Марковой, ВВ Афанасьева, ЭК Цыбулькина, МВ Неженцева. СПб.: Интермедика; 1998. 304 с.

132. Клюева НГ, Роскин ГИ. Биотерапия злокачественных опухолей. М.: Изд-во АМН CCCP; 1946. 224 c.
133. Клюева НГ, Роскин ГИ. Проблема противораковых антибиотиков. Обратное развитие злокачественных опухолей под влиянием факторов микробного происхождения. М.: Гос. контрольный ин-т сывороток и вакцин им. ПА Тарасевича; 1957. 247 с.

134. Клиот ЕА. Почем путевка в жизнь (литературная запись ЛН Аникина). СПб.: Дмитрий Булавин; 2008. 224 с.

135. Кокряков ВН. Биология антибиотиков животного происхождения. СПб.: Наука; 1999. $162 \mathrm{c}$.

136. Комитет экспертов ВОЗ по лекарственной зависимости. 20-й доклад. Всемирная Организация Здравоохранения. Серия технических докладов. № 551. Всемирная Организация Здравоохранения. Женева (М.: Медицина); 1975. 109 с.

137. Комитет экспертов ВОЗ по лекарственным средствам, вызывающим зависимость. 14 доклад. Всемирная Организация Здравоохранения. Серия технических докладов. № 312 . Всемирная Организация Здравоохранения. Женева (М.: Медицина); 1966. 20 с.

138. Кондрашенко ВТ. Девиантное поведение у подростков: социально-психологические и психиатрические аспекты. Минск: Беларусь; 1988. 207 c.

139. Конечный Р, Боухал М. Психология в медицине. Прага: Авиценум; 1974. 405 с.

140. Корнилов КН. Учение о реакциях человека с психологической точки зрения (Реактология). М.: Госиздат; 1921. 228 с.

141. Косарев СЮ. Ядовитые вещества как средство совершения противоправных деяний. В кн.: теория и практика противодействия незаконному обороту наркотиков. Материалы Всероссийской научно-практической конференции 15-16 декабря 2009 г. Часть 2. Ленинградская обл.: СЗ ИПК ФСКН России; 2011 с. 168-72.

142. Костюченко АЛ, Дьяченко ПК. Внутривенный наркоз и антинаркотики. СПб.: ДЕАН; $1998.240 \mathrm{c}$.

143. Кочерина НВ, Драгавцев ВА. Введение в теорию эколого-генетической организации полигенных признаков растений и теорию селекционных индексов. СПб.: Салезианский центр «Дон Боско»; 2008. 88 с.

144. Коэн ШТ, Вейсс Р. Злоупотребление наркотическими веществами и психические заболевания. В кн.: Наркология. М.: Бином; СПб.: Невский проспект; 1998. с. 275-85.

145. Крафтъ-Эбингъ Р. Учебник психиатрии. 3-е русск. изд. СПб.: Издание КЛ Риккера; $1897.889 \mathrm{c}$.

146. Кречетович ЛМ. Ядовитые растения, их польза и вред. М.; Л.: Сельхозиздат; 1931. 317 с.

147. Кронтовский АА. Наследственность и конституция. Практическое пособие к исследованию патологической наследственности и конституции человека. Киев: Гос. из-во Украины; 1925. 189 с.

148. Куприянов ВВ, Бородин ЮИ, Караганов ЯЛ, Выренков ЮЕ. Микролимфология. М.: Медицина; 1983. 288 с.

149. Куприянов ВВ, Караганов ЯЛ, Козлов 
ВИ. Микроциркуляторное русло. М.: Медицина; 1975. 216 с.

150. Купцов АИ. Введение в географию культурных растений. М.: Наука; 1975. 295 с.

151. Курение и здоровье (Материалы МАИР). Ред. ДГ Заридзе, Р Пето. М.: Медицина; 1989. $384 \mathrm{c.}$

152. Лазарев НВ. Наркотики. Л.: Изд-во Инта гигиены труда и профессиональных заболеваний Ленгорздравотдела; 1940. 400 с.

153. Лазарев НВ. Общее учение о наркотиках и наркозе. Пять публичных лекций. Л.: Изд-в BMA; 1958. 124 c.

154. Лазурский АФ. Классификация личностей. Петроград: Гос. изд-во; 1922. 401 с.

155. Лайне М. Криминология и социология отклоненного поведения. Вып. 1. Хельсинки: Центр обучения тюремных служащих; 1994. 173 с.

156. Лакин КМ, Крылов ЮФ. Биотрансформация лекарственных веществ. Общие вопросы. М.: Медицина; 1981. 342 с.

157. Лакосина НД, Трунова ММ. Неврозы, невротические развития личности. Клиника и лечение. М.: Медицина; 1994. 192 с.

158. Лапин ИП. Личность и лекарство. Введение в психологию фармакотерапии. СПб.: ДЕАН; 2001. 416 с.

159. Лафицкая НВ. Феномен агрессии у вида Homo sapiens. Пытки и казни. СПб.: Невская жемчужина; 2006. 223 с.

160. Лебединский МС, Мясищев ВН. Введение в медицинскую психологию. Л.: Медицина; 1966. 430 с.

161. Лильин ЕТ, Трубников ВИ, Ванюков ММ. Введение в современную фармакогенетику. М.: Медицина; 1984. 157 с.

162. Листов МВ. Химическая защита у членистоногих и изменчивость организмов. Л.: Наука; 1989. 157 с.

163. Лосев ИВ. Комплексное исследование и оценка наркоситуации (мониторинг). В кн.: Теория и практика противодействия незаконному обороту наркотиков. Материалы Всероссийской научно-практической конференции 15-16 декабря 2009 г. Часть 2. Ленинградская обл.: СЗ ИПК ФСКН России; 2010. c. $7-13$.

164. Лужников ЕА. Клиническая токсикология. М.: Медицина; 1994. 225 с.

165. Любченко ПН. Интоксикационные заболевания органов пищеварения. Воронеж: Издво Воронежского ун-та; 1990. 182 с.

166. Майский АИ, Ведерникова НН, Чистяков ВВ, Лакин ВВ. Биологические аспекты наркоманий. М.: Медицина; 1982. 256 с.

167. Маккьюсик ВА. Наследственные признаки человека. М.: Медицина; 1976. 684 с.

168. Максимов МТ. Защита от сильнодействующих ядовитых веществ. М.: Энергоатомиздат; 1993. 175 с.

169. Мальцева ММ, Котов ВВ. Опасные действия психических больных. Психопатологические механизмы и профилактика. М.: Медицина; 1995. $256 \mathrm{c.}$

170. Малюхин ДМ. Некоторые аспекты рационального использования растений рода Can- nabis, а также меры, способствующие эффективному противодействию их неправильного культивирования на территории Российской Федерации. Жизнь. Безопасность. Экология. СПб. 2011;(1-2):85-9.

171. Маляревская АЯ. Обмен веществ у рыб в условиях антропогенного евтрофирования водоемов. Киев: Наукова думка; 1979. 256 с.

172. Мариковский ПИ. Тарантул и каракурт. Морфология, биология, ядовитость. Фрунзе: Изд-во АН Киргизской ССР; 1956. 281 с.

173. Матвеев ВФ. Психические нарушения при дефектах зрения и слуха. М.: Медицина; 1987. $184 \mathrm{c}$.

174. Матюхин BA, Разумов АН. Экологическая физиология человека и восстановительная медицина. М.: ГЕЭТАР Медицина; 1999. 336 с.

175. Машковцев МФ. Химия табака. М.: Пищевая промышленность; 1971. 271 с.

176. Медведев ЮА. Танатологический анализ в патологоанатомической практике. СПб.: Российский нейрохирургический ин-т им. проф. АЛ Полевнова; 2006. 174 с.

177. Международная классификация болезней (десятый пересмотр). Классификация психических и поведенческих расстройств. Клинические описания и указания по диагностике. Перев. под ред. ЮД Нуллера и СЮ Циркина. МКБ-10. ВОЗ. СПб.: АДИС; 1994. $300 \mathrm{c.}$

178. Мерфи ЭА, Чейз ГА. Основы медико-генетического консультирования. М.: Медицина; $1979.398 \mathrm{c.}$

179. Механизмы воздействия зоотоксинов. Межвузовский сборник. Ред. кол. БН Орлов (отв. ред.) и соред. Вып. 4. Горький: Горьковский гос. ун-т им. НИ Лобачевского; 1976. 106 с.

180. Механизмы воздействия зоотоксинов. Межвузовский сборник. Ред. кол. БН Орлов (отв. ред.) и соред. Вып. 5. Горький: Горьковский гос. ун-т им. НИ Лобачевского; 1977. 159 с.

181. Механизмы воздействия зоотоксинов. Межвузовский сборник. Ред. кол. БН Орлов (отв. ред.) и соред. Горький: Горьковский гос. ун-т им. НИ Лобачевского; 1978. 133 с.

182. Механизмы воздействия зоотоксинов. Межвузовский сборник. Ред. кол. БН Орлов (отв. ред.) и соред. Горький: Горьковский гос. ун-т им. НИ Лобачевского; 1980. 157 с.

183. Механизмы воздействия зоотоксинов. Межвузовский сборник. Ред. кол. БН Орлов (отв. ред.) и соред. Горький: Горьковский гос. ун-т им. НИ Лобачевского; 1981. 127 с.

184. Микава АГ. Наркоконтроль в ЛПУ. Работа над ошибками необходима. (Беседовала В Захарова). Медицина Петербурга. 2010; (1(308)):2-3.

185. Миллер Дж, Галантер Е, Прибрам К. Планы и структура поведения. М.: Прогресс; 1965. $238 \mathrm{c}$.

186. Мильштейн ГИ, Спивак ЛИ. Психомиметики. Л.: Медицина; 1971. 149 с.

187. Минюков Д, Теплов Э, Теплова Н. Пьянство, алкоголизация, политика и национальная безопасность. Жизнь и безопасность. СПб. 1999;(3-4):77-93. 
188. Молоковский ДС, Григорьев ВА. Принудительное лечение больных опийной наркоманией. Фармакотерапевтические возможности доказательной наркологии для удержания больных в лечебно-реабилитационных программах. В кн.: Деятельность правоохранительных органов и специальных служб в сфере противодействия незаконному обороту наркотиков: вопросы организации, координации, взаимодействия и международного сотрудничества. Материалы Международной научнопрактической конференции 15-16 декабря 2010 года. Часть 1. Государственная политика, взаимодействие органов власти, общественно-государственное партнерство и международное сотрудничество в сфере противодействия незаконному обороту наркотиков. Ленинградская обл.: СЗ ИПК ФСКН России; 2011. с. 146-57.

189. Мосунов СА, Цапенко ЛВ. Изучение частоты встречаемости двойных гамет у сортов табака коллекции ВНИИТТИ. В кн.: Тезись докладов II Павловской международной конференции 26-30 ноября 2007 г. «Генетические ресурсы культурных растений в XXI веке. Coстояние, проблемы, перспективы». СПб.: Всероссийский ин-т растениеводства им. НИ Вавилова; 2007. с. 314-5.

190. Муцениеце АЯ. Онкотропизм вирусов и проблема виротерапии злокачественных опухолей. Рига: Зинатне; 1972. 443 с.

191. Надеждин АВ. Токсикомания, вызванная летучими углеводородами: Эпидемиология, клиника, лечение. М.: Медпрактика; 2004. 28 с.

192. Наркология. Ред. ЛС Фридман, НФ Флеминг, ДХ Робертс, СЕ Хайман. М.: Бином; СПб.: Невский диалект; 1998. 317 с.

193. Незаконный оборот наркотиков. Глобальные тенденции и проблемы. Сборник докладов Международного комитета по контролю над наркотиками. Сост. АВ Федоров. М.: Астрея-центр; 2007. 296 с.

194. Никитин АВ, Щербич АН, Щербич ЛА. Мониторинг в сфере оборота наркотиков. СПб.: Филиал Всероссийского научно-исследовательского ин-та Мин. внутр. дел России по СЗФО, СПб. ун-т Министерства внутренних дел России; 2009. 104 с.

195. Никитин АВ, Щербич АН, Щербич ЛА Нормативно-правовое обеспечение профилактики возникновения чрезвычайных ситуаций, связанных с незаконным оборотом наркотиков. СПб.: Федеральная служба РФ по контролю за оборотом наркотиков, Филиал Всероссийского научно-исследовательского ин-та Мин. внутренних дел России по СЗФО; 2010. 180 с.

196. Обезболивание при раке. Перев. на рус. яз. ВА Косаренковой. Женева: ВОЗ; 1988. 75 с.

197. Обеспечение экологической безопасности при использовании генетически модифицированных организмов. Сборник материалов Круглого стола Всероссийской конференции по экологической безопасности (4-5 июня 2005 г.). Ред. кол. АС Баранов, ОН Кревер, OA Разбаш. М.: Росс. регион. экологич. центр, Ин-т биологии развития РАН, Центр экологич. политики России, представительство МСОП -
Всемирного Союза Охраны Природы для России и стран СНГ; 2002. 255 с.

198. Обращение к родителям и учителям об опасности наркомании. Жизнь и безопасность. 1998;(4):369.

199. Обуховский К. Психология влечений человека. М.: Прогресс; 1971. 247 с.

200. Озерецковский ДС. Навязчивые состояния. М.: Медгиз; 1950. 168 с.

201. Ойгензихт ВА. Воля и волеизъявление (очерки теории, философии и психологии права). Душанбе: Дониш; 1983. 256 с.

202. Оксенгендлер ГИ. Антидоты высокотоксичных веществ. Л.: 1-й Медицинский ин-т им. ИП Павлова; 1979. 84 с.

203. Оксенгендлер ГИ. Яды и противоядия. Л.: Наука; 1982. 191 с.

204. Оксенгендлер ГИ. Яды и противоядия. Проблемы химической опасности. СПб.: Наука; 1991. 320 с.

205. Онкотропизм вирусов. Ред. кол. ТЭ Стурис, АЯ Муцениеце, МА Александрова, ИД Чернобаева, АА Волрат. Рига: Зинатне; 1969. $222 \mathrm{c}$.

206. Операция «Допинг». Жизнь и безопасность. СПб. 1999;(304):216-9.

207. Орлов БН, Гелашвили ДБ. Зоотоксинология (ядовитые животные и их яды). М.: Высш. школа; 1985. 280 с.

208. Орлов БН, Гелашвили ДБ, Ибрагимов ДН. Ядовитые животные и растения СССР. М.: Высш. школа; 1990. 272 с.

209. Орлов БН, Гелашвили ДБ, Кузнецова МА. Ядовитые беспозвоночные животные и их яды. Горький: Горьковский гос. ун-т им. НИ Лобачевского; 1981. 93 с.

210. Орлов БН, Гелашвили ДБ. Зоотоксинология (Ядовитые животные и их яды). М.: Высш. школа; 1985. 280 с.

211. Павловский ЕН. К вопросу о строении ядовитых желез суставчатоногих. В кн.: Труды Санкт-Петербургского общества естествоиспытателей. СПб. 1912-1913;(43(2)):1-190.

212. Павловский ЕН. К строению и развитию ядовитых желез скорпионов. Русское энтомологическое обозрение. 1914;(14(1)):57-69.

213. Павловский ЕН. Руководство по паразитологии человека с учением о переносчиках трансмиссивных болезней. Т. 1. 5-е изд. М.; Л.: Изд-во АН СССР; 1946. 521 с.

214. Павловский ЕН. Руководство по паразитологии человека с учением о переносчиках трансмиссивных болезней. Т. 2. 5-е изд. М.; Л.: Изд-во АН СССР; 1948. с. 527-1022.

215. Павловский ЕН. Природная очаговость трансмиссивных болезней в связи с ландшафтной эпидемиологией зооантропонозов. М.; Л.: Наука; 1964. 211 с.

216. Палилова АН. Нехромосомная наследственность. Минск: Наука и техника; 1981. 184 с.

217. Парк Деннис В. Биохимия чужеродных соединений. М.: Медицина; 1973. 288 с.

218. Педли Т. Гидродинамика крупных кровеносных сосудов. М.: Мир; 1983. 400 с.

219. Петрович СВ. Микотоксикозы животных. М. Росагропромиздат; 1991. 238 с. 
220. Познанский АС. Влияние кофеина на галлюцинации. Сов. психоневрология. 1936;(7):18-22.

221. Попов ЮВ. Профилактика и коррекция саморазрушающего поведения у подростков. Пособие для врачей. СПб.: Санкт-Петербургский научно-исследовательский психоневрологический ин-т им. ВМ Бехтерева; 1995. 21 с.

222. Потапов А. О наших ядовитых животных. Жизнь и безопасность. СПб. 1999;(34):441-51.

223. Потапов ЛП. Охотничий промысел алтайцев (Отражение древнетюркской культуры в традиционном охотничьем промысле алтайцев). СПб.: Музей антропологии и этнографии им. Петра Великого (Кунсткамера) РАН; 2001. 167 с.

224. Пошивалов ВП. Экспериментальная психофармакология агрессивного поведения. Л.: Наука, 1986. 175 с.

225. Примроуз С, Тваймен Р. Геномика. Роль в медицине. М.: Бином. Лаборатория знаний; 2008. 277 c.

226. Противораковый антибиотик круцин. Ред. ЛБ Левинсон, НГ Клюева. М.: Изд-во МГУ; 1968. 360 с.

227. Радкевич ПЕ. ветеринарная токсикология. М.: Колос; 1972. 231 с.

228. Раут ЧП, Стефен А, Косовски Б. Внутриутробные последствия злоупотребления наркотическими веществами. Наркология. М.: Бином; СПб.: Невский проспект; 1998. с. 257-74.

229. Ревуненкова ЕВ. Ритуально-символическая роль бетеля в малайско-индонезийском регионе в прошлом и настоящем. В кн.: Научные исследования и музейные проекты Музея антропологии и этнографии им. Петра Великого (Кунсткамеры) РАН в 2008 г. Радловский сборник. СПб.: Музей антропологии и этнографии РАН; 2008. с. 459-63.

230. Реньяр П. Умственные эпидемии. Демонизм, истерия, гипнотизм и мания величия. M.: Emergency Exit; 2004. 296 c.

231. Руководство по психиатрии. Т. 1. Ред. АВ Снежневский. М.: Медицина; 1983a. 480 с.

232. Руководство по психиатрии. Т. 2. Ред. АВ Снежневский. М.: Медицина; 1983б. 544 с.

233. Русалов ВМ. Биологические основы индивидуальных психологических различий. М.: Наука; 1979. 352 с.

234. Рутовский БН. Эфирные масла. Т. 1. Способы получения эфирных масел и их анализ. М.; Л.: Гос. изд-во сельскохозяйственной и колхозно-кооперативной литературы; 1931. $594 \mathrm{c}$.

235. Рыбальский МИ. Иллюзии и галлюцинации. Систематика, семиотика, нозологическая принадлежность. Баку: Маариф; 1983. 303 с.

236. Сакевич АИ. Экзометаболиты пресноводных водорослей. Киев: Наукова думка; 1985. $199 \mathrm{c}$.

237. Сапин МР, Борзяк ЭИ. Внеорганные пути транспорта лимфы. М.: Медицина; 1982. 264 c.

238. Сафаев РД, Заридзе ДГ, Белицкий ГА, Джорджеви М, Бруннеман К. Канцерогенные вещества в табаке и дыме сигарет: полицикли- ческие ароматические углеводороды, металлы, пестициды. Экспериментальная онкология. 1992;(3):25-9.

239. Сафьянов ВА, Медведев ВН. К вопросу о противодействии незаконному обороту наркотических средств, изготавливаемых из семян пищевого мака. В кн.: Деятельность правоохранительных органов и специальных служб в сфере борьбы с незаконным оборотом наркотиков. Материалы Всероссийской научно-практической конференции 18-19 декабря 2008 года. Часть 3. Раскрытие и исследование преступлений в сфере незаконного оборота наркотиков. Ленинградская обл.: С3 ИПК ФСКН России; 2009. с. 19-21.

240. Сахаров ГП. Методология патологии. М.: Изд-е научно-исследовательской лаборатории экспериментальной терапии; 1934. 112 с.

241. Светлов ПГ. Теория критических периодов развития и ее значение для понимания принципов действия среды на онтогенез. Вопросы цитологии и общей физиологии. Ред. ЮИ Полянский. М.; Л.: Изд-во АН СССР; 1960. c. 263-85.

242. Сидякин ВГ. Влияние глобальных экологических факторов на нервную систему. Киев: Наукова думка; 1986. 160 с.

243. Синицкий ВН. Депрессивные состояния (патофизиологическая характеристика, клиника, лечение, профилактика). Киев: Наукова думка; 1986. 272 с.

244. Синская ЕН. Историческая география культурной флоры (на заре земледелия). Л.: Колос; 1969. 479 с.

245. Сиренко ЛА, Гавриленко МА. «Цветение» воды и евтрофирование (методы его ограничения и использования сестона). Киев: Наукова думка; 1978. 231 с.

246. Сиренко ЛА, Козицкая ВН. Биологически активные вещества водорослей и качество воды. Киев: Наукова думка; 1988. 256 с.

247. Слепянъ СН (отец Сергий). «О пьянстве». СПб.; 1886.16 с.

248. Слепянъ СН (отец Сергий). «О табаке». Беседа. 3-е изд. СПб.: Тип. ПП Сойкина; 1897. $16 \mathrm{c}$.

249. Слепянъ СН (отец Сергий). «Поученіе противъ пьянства». 9-е изд. М.: Отдел распространения духовно-нравственных книг; 1891. 15 с.

250. Слепянъ СН (отец Сергий). «Пьянствоокаянство». 5-е изд. СПб.: Тип. АВ Пожаровой; 1893. $16 \mathrm{c}$.

251. Слепян ЭИ. К вопросу об изученности растений флоры России, содержащих психотропные вещества (в связи с проблемой наркомании, обусловленной потреблением фитонаркотических средств). В кн.: Деятельность правоохранительных органов и специальных служб в сфере борьбы с незаконным оборотом наркотиков. Материалы Всероссийской научно-практической конференции 18-19 декабря 2008 г. Ч. 1. Ленинградская обл.: СЩ ИПК ФСКН России; 2009. с. 65-81.

252. Слепян ЭИ. Критерии ненасилия и насилия и интеллектуальное развитие. VII Международный конгресс Международной ассо- 
циации работников просвещения За мир во всем мире 22-27 мая 1994 г. Тезисы. Ч. 1. СПб. c. $152-62$.

253. Слепян ЭИ. Магнолиофиты и их психотропное воздействие. В кн.: Теория и практика противодействия незаконному обороту наркотиков. Материалы Всероссийской научно-практической конференции 15-16 декабря 2009 г. Ч. 1. Ленинградская обл.: СЗ ИПК ФСКН России; 2010. с. 49-61.

254. Слепян ЭИ. Преморбидная диагностика при экологической экспертизе - основа контроля за состоянием биоты. В кн.: Проблемы донозологической гигиенической диагностики. Материалы научной конференции 23-25 мая 1989 г. Л.: Наука; 1989. с. 49-51.

255. Слепян ЭИ. Система патогенных агентов, факторов риска и патотропных ситуаций в аспекте Естественно-научной картины Мира. В кн.: Биологическая индикация в антропоэкологии. Материалы Второго Всесоюзного совещания по космической антропоэкологии 2-6 июня 1984 г. Л.: Наука; 1984. с. 6-62.

256. Слепян ЭИ. Стратегия озеленения, категории растений-озеленителей и проблемы сохранения и оздоровления городской природной среды. В кн.: Озеленение, проблемы фитогигиены и охрана городской природной среды. Л.: Зоологический ин-т АН СССР; 1984. с. 138-230.

257. Слепян ЭИ. Сущность экологии, экологический терроризм и экологическая информация, имеющая юридическое значение. В кн.: Правовые аспекты обеспечения экологической безопасности. Материалы эколого-правового форума 28-29 октября 2004 г. М.: ИД «Жизнь Безопасность. Экология». Спецвыпуск; 2004. c. $9-14$.

258. Слепян ЭИ. Экологическая опасность, экологическая безопасность и создание системы экологической защиты. В кн.: Экологическая адаптация общества на постсоветском пространстве. М.: Междисциплинарный институт экологических проектов; 2000. с. 14-27.

259. Слепян ЭИ. Экологический риск. Региональная экология. СПб. 2002;(1-2):62-82.

260. Слепян ЭИ. Экологический терроризм (предпосылки и система). Труды Девятой Всероссийской научно-практической конференции «Актуальные проблемы защиты и безопасности. Технические средства противодействия терроризму и оружие нелегального действия». Ред. ВА Петров, МВ Сильников, АГ Комяженко. Т. 1. СПб.: Научно-производственное объединение специальных материалов; 2206. с. 73-98.

261. Слепян ЭИ. Экологический терроризм как особая категория терроризма. В кн.: Научные аспекты экологических проблем России. Труды 2 Всероссийской научной конференции 29-31 мая 2006 г. Ред. ЮА Израэль. М.: Метеоагентство Федеральной службы по гидрометеорологии и мониторингу окружающей среды; 2006. С. 239-43.

262. Слепян ЭИ. Экологический терроризм: сущность, следствия и условия их ликвидации Жизнь и безопасность. СПб. 2002;(1-2):277-83.
263. Слепян ЭИ. Экология, экологическая опасность, экологическая безопасность и характеристики жизни человека. Повышение качества жизни населения - важнейшая проблема Российской Федерации. Сборник научных статей по материалам 2 Международного форума «Качество жизни: содружество науки, власти, бизнеса и общества». Москва 16-17 ноября 2004 г. Ч. 2. М.: Муниципальный мир; 2005. с. 203-20.

264. Слепян ЭИ. Экологический терроризм. Машины и механизмы. СПб. 2009;(7):101-4.

265. Слепян ЭИ, Петрова НР. Возможные проявления экологического терроризма в пространстве составляющих Единой транспортной системы и Единой транспортной системы в целом. Организация безопасности дорожного движения в крупных городах. Сборник докладов Пятой Международной конференции. Без ред. СПб.: Научно-исследовательский центр безопасности дорожного движения при Автомобильном дорожном институте СанктПетербургского гос. архитектурно-строительного университета; 2002. с. 86-103.

266. Слепян ЭИ. Зигмунд Фрейд и нейропсихотропный стимулятор наркотик кокаин - природное соединение, синтезируемое растениями - представителями родов Cola и Erythroxylon. Антинаркотическая безопасность: Ленинградская обл. Поселок Мурино. ФКОУ ДПО «Северо-Западный институт повышения квалификации ФСКН России». 2015;(1(4)январь-июнь):34-96.

267. Слепян ЭИ. Наркомания как социальная аномалия и ее экологическая зависимость. Аналитическое рассмотрение проблемы. В кн.: Слепян ЭИ. Сборник научных статей по проблемам наркомании. Ленинградская обл. Всеволожский район, поселок Мурино: С3 ИПК ФСКН России; 2013. с. 49-181.

268. Смирнов ВП, Фадеев МЮ. Болезни накопления (тезаурислозы). Н. Новгород: Изд-во НГМА; 2007. 102 с.

269. Смирнов ИВ. Психоэкология. М.: НИИ психотехнологий Российского университета дружбы народов; 2003. 336 с.

270. Смит Т, Смит К. Механизмы обратной связи в управлении поведением человека. В кн.: Человеческий фактор. Т. 1. Ред. АИ Назаренко. М.: Мир; 1991. с. 486-563.

271. Современные подходы к болезни Дауна. Под ред. Давида Лейна и Бриайна Стэтфорда. М.: Педагогика; 1951. 333 с.

272. Соколов ВЕ. Систематика млекопитающих. Отряды: китообразных, хищных, ластоногих, трубкозубых, хоботных, даманов, сирен, парнокопытных, мозоленогих, непарнокопытных. М.: Высш. школа; 1979. 528 с.

273. Спесивцева НА. Микозы и микотоксикозы. М.: Колос; 1964. 520 с.

274. Стенько ЮМ, Михельсон ДА, Родников АВ. Опасные морские животные. М.: Пищевая промышленность; 1984. 65 с.

275. Столяров ГВ. К вопросу о кофеиномании (теизме). В кн.: Психические нарушения при интоксикациях и органических поражениях головного мозга. Труды 1-го Московско- 
го медицинского института им. ИМ Сеченова. T. 27. Ред. ВМ Банщиков, ВВ Русских. М.: 1-й Московский медицинский институт им. ИМ Сеченова; 1963. с. 31-7.

276. Султанов МН. Укусы ядовитых животных. М.: Медицина; 1977. 192 с.

277. Сусков ИИ, Сазонова ЛА. Мутагенные эффекты химических соединений у человека. В кн.: Успехи современной генетики. Вып. 11. М.: Наука; 1983. с. 93-132.

278. Сухановъ СА. О галлюцинаторных навязчивых представлениях и навязчивых галлюцинациях. Русский врачъ. 1904;(45):1503-7.

279. Талызин ФФ. Ядовитые животные суши и моря. М.: Знание; 1970. 96 с.

280. Тамбиев AX. Летучие вещества, запахи и их биологическое значение. М.: Знание (Новое в жизни, науке, технике. Сер. «Биология». № 8); 1974. 64 c.

281. Танасиенко ФС. Эфирные масла. Содержание и состав в растениях. Киев: Наукова думка; 1985. 264 с.

282. Тангиев ББ. Криминология экологической преступности (криминологический уголовно-правовой анализ). СПб.: ГеоГраф; 2004. 156 с.

283. Тангиев ББ. Экологическая преступность - основная угроза национальной безопасности России (уголовно-правовое исследование). СПб.: ГеоГраф; 2004. 179 с.

284. Ташмухамедов БА, Усманов ПБ. Нейротоксины в исследовании биологических мембран. М.: Высш. школа; 1991. 113 с.

285. Ткаченко ЕС. Токсическое действие микроскопических грибов. М.: Медицина; 1973. $135 \mathrm{c}$.

286. Томилин МГ. Взаимодействие жидких кристаллов с поверхностью. СПб.: Политехника; 2001. 325 с.

287. Томилин МГ, Невская ГЕ. Фотоника жидких кристаллов. СПб.: Изд-во Политехнического университета; 2011. 742 с.

288. Трошин ВД, Шубина ЛП. Теоретические и методологические основы нейропрофилактики. Новосибирск: Наука; 1988. 236 с.

289. Тутельян ВА, Кравченко ЛВ. Микотоксины (медицинские и биологические аспекты). М.: Медицина; 1985. 319 с.

290. Тыщенко ВП. Определитель пауков Европейской части СССР. Определители по фауне СССР, издаваемые Зоологическим институтом АН СССР. Вып. 105. Л.: Наука; 1971. 281 с.

291. Тюкавкина НА, Литвиненко ВИ, Шостаковский МФ. Хроматография на полиамидных сорбентах в органической химии. Новосибирск: Наука; 1973. 176 с.

292. Улитин АЮ, Олюшин ВЕ, Иванова НЕ. Церебральные лимфомы, иммунодефицитные состояния, наркозависимость. В кн.: Теория и практика противодействия незаконному обороту наркотиков. Материалы Всероссийской научно-практической конференции 15-16 декабря 2009 года. Ленинградская обл.: СЗ ИПК ФСКН России; 2010. с. 182-6.

293. Уфлянд ЮМ. Теория и практика хронаксиметрии. Л.: 2-й Ленинградский медицинский институт; 1938. 298 с.
294. Ушман Г. Определение Эрнстом Геккелем понятия «экология». В кн.: Очерки по истории экологии. Ред. кол. ГА Новиков, СС Шварц, ЛВ Чеснова. М.: Наука; 1970. с. 10-21.

295. Федоров АлА, Федоров АнА. Два года в Саянах. М.: Географгиз; 1951. 348 с.

296. Федоров АлА, Пименов МГ. Хемосистематика, ее проблемы и практическое значение. Сообщение 1. Растительные ресурсы. 1967;(III(1)):3-16.

297. Федоров АлА, Пименов МГ. Хемосистематика, ее проблемы и практическое значение. Сообщение 2. Растительные ресурсы. 1970;(VI(1)):19-25.

298. Федоров ЛЮ. Рассказы о ядах, противоядиях, лекарствах и ученых. М.: Знание (наука и прогресс); 1983. 124 с.

299. Флеминг НФ, Поттер Д, Кэттил С. Злоупотребление наркотическими веществами и пристрастие к употреблению наркотических веществ. Наркология. М.: Бином; СПб.: Невский диалект; 1998. с. 15-26.

300. Фрейд 3. По ту сторону принципа удовольствия. В кн.: Фрейд 3. Психология бессознательного. Сборник произведений. Сост., научн. ред. и авт. вступ. ст. МГ Ярошевский. М.: Просвещение; 1990. с. 382-424.

301. Фролова Н, Халлберг Т, Зазулин Г. Практика антинаркотической деятельности городов и направления ее совершенствования. Вып. 1. М.: Орбита-М; 2005. 160 с.

302. Фролова НА, Зазулин ГВ. Актуальные вопросы антинаркотической политики: отечественный и зарубежный опыт. Научно-практическое издание. М.; СПб.; 2003. 272 с.

303. Фурст ДжБ. Невротик. Его среда и внутренний мир. М.: Изд-во иностранной литературы; 1957. 375 с.

304. Хагеман Р. Плазматическая наследственность. М.: Изд-во иностранной литературы; 1962. 111 с.

305. Харабет КВ. К вопросу о разработке концепции наркотической безопасности. В кн.: Деятельность правоохранительных органов и специальных служб в сфере противодействия незаконному обороту наркотиков: вопросы организации, координации, взаимодействия и международного сотрудничества. Материалы Международной научно-практической конференции 15-16 декабря 2010 года. Ленинградская обл.: СЗ ИПК ФСКН России; 2011 с. 222-8.

306. Харпер П. Практическое медико-генетическое консультирование. М.: Медицина; 1984. $302 \mathrm{c}$.

307. Худолей ВВ, Балански РМ. Курение табака как фактор онкологического риска. Вопросы онкологии. 1989;(11):1283-90.

308. Чеботарь АА, Ботнаренко ПМ. Дурман, систематика, биология развития, мутагенез. Кишенев: Штиинца; 1978. 60 с.

309. Черкесов ВВ, Михайлов АГ, Харичкин ОН, Целинский БП, Печанских ГВ, Саповский ММ, Миронов АС, Нестеров ВН, Кашинцев СВ, Стародубов ВИ, Какорина ВП, Егоров ВФ, Черешнев ВА, Россель ЭЭ, Ковалева ГА, Самкова НП, Духова НИ, Татаркин АИ, 
Куклин АА, Калина АВ, Нифантова РВ, Быстрай ГВ, Гурбан ИА, Комаровская АА, Михайлова ЮВ, Соя ИМ, Мейснер АФ, Леонов СА, Богатырев ЛЛ, Мызин АЛ, Левченко РЮ, Дьячков АA, Тетерина ИГ, Клевакин АН, Шмакова ИВ, Гибанова ТН, Штоль АВ, Ружников ЮН, Сердюк ЮВ. Наркоиммунитет региона: социально-экономический и медикобиологический аспекты. М.: Экономика; 2004. $324 \mathrm{c}$.

310. Чернух АМ, Александров ПН, Алексеев ОВ. Микроциркуляция. М.: Медицина; 1975. $456 \mathrm{c}$.

311. Шабанов ПД. Руководство по наркологии. СПб.: Лань; 1998. 352 с.

312. Шабунин ДА. Реальность получения биомассы продуцентов каннабиноидов в условиях in vitro. Жизнь. Безопасность. Экология. СПб. 2009;(3-4):187-9.

313. Шейнерман НМ, Сыровежко НВ, Слепян ЭИ. Об отсутствии бластомогенных углеводородов в «мумиё» и в препарате «нас». В кн.: Растения и химические канцерогены. Под ред. ЭИ Слепяна. Л.: Наука; 1979. с. 144-6.

314. Шор ГВ. О смерти человека. Введение в танатологию. СПб.: Изд-во Санкт-Петербургского государственного медицинского университета; 2002. 272 с.

315. Штерн К. Основы генетики человека. М. Медицина; 1965. 690 с.

316. Щербич АН. Определение профилактики возникновения чрезвычайных ситуаций, связанных с незаконным оборотом наркотиков. В кн.: Теория и практика противодействия незаконному обороту наркотиков. Материалы Всероссийской научно-практической конференции 15-16 декабря 2009 года. Ч. 2. Ленинградская обл.: СЗ ИПК ФСКН России; 2010. с. 84-91.

317. Щербич АН. Опыт противодействия шведского общества наркоэпидемии. В кн. Антинаркотическая политика: шведские ответы на российские вопросы. СПб.: Изд-во СПбГУ; 2008. с. 187-96.

318. Энтеросорбция. Ред. НА Беляков. Л.: Центр сорбционных технологий; 1991. 329 с.

319. Эпигенетика. Ред. СД Элпис, Т Джеювейн, Д Рейнберг. М.: Техносфера; 2010. 495 с.

320. Эпилепсия излечивается. Жизнь и безопасность. СПб. 1999;(3-4):334-40.

321. Эпштейн АЛ. Невротическая конституция (Общая часть). Л.: Практическая медицина; 1927. 127 с.

322. Эфроимсон ВП. Введение в медицинскую генетику. М.: Медицина; 1968. 395 с.

323. Юдин ТИ. Психопатические конституции. Выделение типов характера (типов сложных психических реакций) на основании наследственно-биологического и клинического анализа психозов. В кн.: Психопатические конституции. М.: Издание М и С Сабашниковых; 1926. $166 \mathrm{c}$.

324. Юнусов СЮ. Алкалоиды. Ташкент: ФАМ; 1974. 320 c.

325. Янин БТ. Основы тафономии. М.: Недра; 1983. $184 \mathrm{c}$
326. Ясан ЭВ. «Комплекс вины» (киносценарий). Жизнь. Безопасность. Экология. СПб. 2009;(1-2):291-315.

327. Ясперс К. Общая психопатология. М.: Практика; 1997. 1056 с.

328. ECAD. Союз «За общество без наркотиков» (RN5). Ред. ГВ Зазулин. СПб.: Изд-во СПбГУ; 2001.99 с.

\section{Общий список литературы/Reference List}

1. Azhgihin IS, Shpakov JN, Kipiani RE, Gandel KV. Morskaya Pharmaciya (Teoriya i Praktika Novogo Napravleniya v Pharma cev ticheskoi Nauke). Kishinev: Shtiinza; 1982.

2. Alekperov UK. Osobennosti Deystviya Antimutagenov i Pespektivi Ikh Primememiya. Uspehi Sovremennoy Genetiki. Sbornik 8. Moscow: Nauka; 1979. p.168-81.

3. Alexandrovskiy AYu. Pogranichnie Psikhicheskie Rasstroistva. Rukovodstvo dla Vrachei. Moscow: Meditsyna; 1993.

4. Albert A. Izbiratelnaya Toksichnost. Physikokkhimicheskie Osnovi Terapii. T. 1. Moscow: Meditsyna; 1989.

5. Albert A. Izbiratelnaya Toksichnost Physikokkhimicheskie Osnovi Terapii. T. 2. Moscow: Meditsyna; 1989.

6. Androsenko GF. Anasha Pod Oknami Milicii. Zhizn i Bezopasnost. 1988;(2-3):210-1.

7. Anichkov SV. Neurofarmakologiya. Rukovodstvo. Leningrad: Meditsyna; 1982.

8. Anichina IP. Neurokhimicheskie Mehanismi Psikhicheskikh Zabolevaniy. Moscow: Meditsyna; 1975.

9. Antonyan YM, Borodin SV. Prestupnost i Psikhicheskie Anomalii. Moscow: Nauka; 1987.

10. Arias F. Beremennost i Rody Vysokogo Riska. Moscow: Meditsyna; 1989.

11. Aristovich VJ, Aristovich JV, Sokolov AJ, Toropkov VV, Bahiz VM, Panicheva SA, Altshul EV. Russkaya vodka - vpered v proshloe. Zhizn i Bezopasnost. 1999;(3-4):94-6.

12. Kava, Kola, Chat, Zhevatelnie Rituali I Mifologii Narodov Mira. Maklaevskiy Sbornik. Vypusk 5. Stanukovich MV, ed. Saint Petersburg. MAE RAN; 2015.

13. Astahova VG. Zagadki Yadovitikh Rasteniy. Moscow: Lesnaya Promishlennost; 1977.

14. Baboyan EA. Putevka AD. Mezhdunorodnie Otnosheniya; Moscow: 1974.

15. Baboyan EA, Gonopolskiy MN. Narkologiya. Moscow: Meditsyna; 1987.

16. Bagrova ND. Factor Vremeni v Vospriyatii Chelovekom. Leningrad: Nauka; 1980.

17. Badalyan LO. Neuropatologiya. Moscow: Prosveshenie; 1982.

18. Badalian LO, Tabolin VA, Veltishev JuE. Nasledstvennie Bolezni U Detei. Moscow: Meditsyna; 1971.

19. Bajkova VG, Brun EA, Garanskiy AN, Kolesnikova TI, Jasonov OV. Narkomania v Rossii: Sostoianie, Tendencii, Puti Preodoleniya. Posobie dla Pedagogov i Roditelei. Moscow: Vlados-Press; 2003.

20. Bakin AA. Vliyanie narkoticheskich preparatov na formirovanie kriminalnoi agressii. Teoriya 
i praktika protivodeistviya nezakonnomu oborotu narkotikov. In: Materialy Vserossiskoi NauchnoPrakticheskoi Konferencii 15-16 Decabrya 2009 G. Chast 1. Murino: SZ IPK FSKN Rossii; 2010. p. 91-4.

21. Balandin RK. Narcozivilizaciya. Mnimaya Realnost. Moscow: Algoritm-Kniga; Eksmo; 2003.

22. Baliekiy KP, Veksler LG, Vinnickiy VB, Syromyatnikov AV, Shmalko JP. Nervnaya Sistema i Protivoopuholevaya Zaschita. Kiev: Naukova Dumka; 1983.

23. Baltkais YaYa, Fateev VYa. Vzaimodeistvie Lekarstvinnikh Veschestv (Farmakoterapevticheskie Aspekti). Moscow: Meditsyna; 1991.

24. Banschikov VM, Stolyarov GV. Novoe psikhomimeticheskoe sredstvo - psilocybin. Psikhicheskie narusheniya pri intoksikaciyah i organicheskikh porazheniyah golodnogo mozga. In: Trudy 1-go Moskovskogo Medicinskogo Instituta Im. IM Sechenova. Tom XXVII. Banschikov VM, Russkikh VV, eds. Moscow: 1-iy Moskovskiy Medicinskiy Institute Im. IM Sechenova; 1963. p 21-30.

25. Bazanov AA, Kuchma VR, Zvezdina IV. Tabakokurenie Detey i Podrostkov. Gigienicheskie i Medico-Sotsyalnie Problem i Puti Ikh Resheniya. Moscow: Literra; 2007.

26. Baranov VS, Baranova EV, Ivaschenko GE, Aseev TV. Genom Cheloveka I Geni Predraspolozhennosti. Vvedenie V Prediktivnuju Medicinu. Saint Petersburg: Intermedika; 2000.

27. Barbie M. Vvedeniye v kkhimicheskuju Ekologiyu. Moscow: Mir; 1978.

28. Barkovskaya EV, Pavlov DV. Narkosituaciya: problemi controlya i monitoringa. Teoriya i praktica protivodeysrviya nezakonnomu oborotu narkotikov. In: Materialy Vserossiskoy NauchnoPrakticheskoi Konferencii 15-16 Dekabrya 2009 G. Chast 2. Murino: SZ IPK FSKN Rossii; 2010. p. 19-23.

29. Barlou R. Vvedenie v Khimicheskuyu Farmakologiyu. Moscow: Izdatelstvo Inostrannoi Literature; 1959.

30. Belenkiy R. Vysokoeffectivniy Kapillarnjy Elektroforez. Saint Petersburg: Nauka, 2009.

31. Belkov O (Otec Sergiy). Vzaimodeistvie Russkoi Pravoslovnoi Cerkvi i Fedaralnoi Sluzbi Rossiskoi Federacii po Kontrolu za Jborotom Veschestv v sfere snizheniya sprosa na antinarkoticheskoi politiki. In: Deyatelnost Pravoohranitelnikh Organov i Specialnikh Sluzb v Sfere Protivodeistviya Nezakonnomu Oborotu Narkotikov: Voprosi Organizacii i Koordinacii, Vzaimodeistviya i Mezhdunarodnogo Sotrudnichestva. Materialy Vsrossiiskoi NauchnoPrakticheskoi Konferencii 15-16 Dekabria 2010 g. Chast 1. Gosudarstvennaya Politika, Vzaimodeistvie Organov Vlasti, ObschestvennoGjsudarstvennoe Partnerstvo i Mezhdunarodnoe Sotrudnichestvo v Sfere Protivodeistviya Nezakonnomu Oborotu Narkotikov. Murino: SZ IPK FSKN Rossii; 2011. p. 8-11.

32. Berdieva FT. K Patogenezu Intoksikacii Yadami Sredneaziatskikh Zmei - Gurzi i Kobri. Ashabad; Ilim; 1972.
33. Bernstein LM. Onkoendocrinologia Kurenia. Saint Petersburg: Nauka; 1995.

34. Behtel EE. Donosologicheskie Formi Zloupotrebleniya Alkogolem. Moscow: Meditsyna; 1986.

35. Beal G, Noulz G. Vneyadernaya Nasledstvennost. Moscow: Mir; 1981.

36. Bilai VI. Biologicheski Aktivnie Veschestva Mikroskopicheskikh Gribov i Ikh Priminenie. Kiev: Naukova Dumka; 1965.

37. Bilai VI. Mikroskopicheskie Gribi Producenti Antibiotikov. Kiev: Izd-vo AN UkrSSR; 1961.

38. Biogeokhimicheskie Cikli v Biosphere. Materialy VII Plenuma SKOPE. Moskva, 15-22 Noyabria, 1974. Kovda VA. ed. Moscow: Nauka; 1976.

39. Biockhimiya Psikhozov. Materialy Simpoziuma Po Khimicheskim Koncepciyam Psikhoza. II Mezdunarodnogo Psikhiatricheskogo Kongressa V Curihe (Schveizaria) 1-7 Sentyabrya 1957 G. Fedotov DD, ed. Moscow: Medgiz; 1963.

40. Birukov DA. Ekologicheskaya Fiziologiya Nervnoi Deyatelnosti (Nekotorye Voprosy Biologicheskikh Osnov Teorii Meditsyny). Leningrad: Medgiz; 1960.

41. Bodrov VE. Nikotinovaya narcomania i posledstbiya tabakokureniya. Teoriya i praktica protivodeistviya nezaconnomu oborotu narkotikov. In: Materialy Vserossiskoi NauchnoPrakticheskoy Conferencii 15-16 Decabrya 2009 G. Chast 1. Murino: SZ IPK FSKN Rossii, 2010. p. 95-100.

42. Boyco EI. Vremya Reakcii Cheloveka. Istoriya, Teoriya, Sovremennoe Sostoianie i Praktichescoe Znachenie Hronometrichescoh Issledovaniy. Moscow: Meditsyna; 1964.

43. Davidenkova EF, ed. Bolezn Dauna Clinichescie i Citogenetichescie Issledovaniya. Leningrad: Meditsyna; 1966.

44. Borba s Potrebleniem Bezdimnogo Tabaca. Doclad Nauchnoi Gruppi VOZ. Seriya Tekhicheskikh Dokladov, N 773. Geneva: VHO; 1991.

45. Bratco AA. Modelirovanie Psikhiki. Moscow: Nauka; 1969.

46. Bratus IN. Khimiya Dushistikh Veschestv. Moscow: Argopromizdat; 1992.

47. Breznev DD, Shmaraev GE. Rastenievodstvo Avstralii. Moscow: Kolos; 1974.

48. Brushlinskiy AV. O nekotorych metodah modelirovaniya $\mathrm{V}$ psyhologii. In. Metodologicheskie i Teretocheskie Problemi. Shorohova EV, ed. Moscow: Nauka; 1969.

49. Burnazian GA. Psikhofarmakoterapiya. Erevan: Ayastan; 1985.

50. Berov JuV, Vedernikova NN. Neurokhimiya i Farmakologiya Alkogolisma. Moscow: Meditsyna; 1985.

51. Bebson SG, Benson RK, Pernoll MP, Benda GI. Vedenie Beremennich S Povichennim Riskom I Intensivnaya Terapiya Novorozhdennogo. Moscow: Meditsyna; 1979.

52. Vavilov NI. Centri Proishozhdeniya Culturnykh Rastenij. Trudy po Prikladnoi Botanike, Genetike i Selekcii. T. 16, N 2. Leningrad; 1926. 
53. Vavilov NI, Bukinich DD. Zemledelcheskiy Afganistan. Trudy po Prikladnoy Botanike, Genetike i Selekcii. Prilozhenie 33. Leningrad; 1929.

54. Vaisov SB. Narkoticheskaya I Alcogolnaya Zavisimost. Prakticheskoe Rukovodstvo dla Detei i Podrostkov. Saint Petersburg: Nauka i Tekhika; 2008.

55. Vaisman GJa, Jampolskaya MM. Priminenie Ionobmennyh Adsorbentov V Farmacevtiheskom Analize. Kiev: Gosmedizdat SSSR; 1959.

56. Valdman AV, Baboyan EA, Zvartau EE. Psikhofarmakologicheskie i Medikopravovie Aspekty Toksicomaniy. Moscow: Meditsyna; 1988.

57. Vasilkov BP. Siedobnie I Iadovitie Gribi Srebnei Polosi Evropeiskoi Chasti SSSR. Opredelitel. Moscow, Leningrad: Izd-vo AN SSSR; 1948

58. Vernadskiy VI. Zhivoe Veschestvo. Moscow: Nauka; 1978.

59. Vernadskiy VI. Razmyshleniya Naturalista. Prostranstvo i Vremya v Nezhivoy i Zhivoy Prirode. Moscow: Nauka; 1975.

60. Vilner AM. Kormovie Otravleniya. Leningrad: Kolos; 1974.

61. Vladimirov VJu. Narkotiki Kak Oruzhie Massovogo Porazhenia Prolongirovannogo I Izbiratelnogo Deystviya. In: Aktuaknye Problemy Biologii i Ekologii. Sbornik Nauchnikh Trudov. Saint Petersburg: Sankt-Peterburgskaya Gosudarstvennaya

Akademiya; 2010. p. 51-64.

62. Vladimirov VYu, Kaimak EV. Rost ispolzovaniya glaznikh kapel «Tropikamid» V kachestve zamenitelya narkoticheskikh sredstv. Biosfera. 2012;(4(1)):86-9.

63. Gasparyan SA, Ostroverhov GE, Trapeznikov NN. Regionarnaya Dlitelnaya Vnutriarterialnaya Khimioterapiya Zlokachestvennikh Opuholey. Moscow: Meditsyna; 1970.

64. Gelashvili DB. Neurogumaralnie Mehanizmi Stressornogo Deystviya Zootoksinov I Fisiologicheskie Osnovi Korrekcii Ikh Povrezhdauschikh Effectov. Tbilisi: Institut Fiziologii im. IS Beritashvili AN GruzSSR; 1989. 65. Genomika - Medicine. Moscow: Akademkniga, 2005.

66.Genofond i Genogeografiya Narodonaseleniya. T. 1. Genofond, Naseleniya Rossii I Sopredelnikh Stran. Richkov JuG, ed. Saint Petersburg: Nauka; 2000.

67. Genofond I Genogeografiya Narodonaseleniya. T. 2. Genogeograficheskiy Atlas Naseleniya Rossii i Sopredelnikh Stran. Richkov JuG, ed. Saint Petersburg: Nauka; 2003.

68. Giliarovskiy VA. Psikhiatriya. Moscow: Medgiz; 1954.

69. Golender VE, Rosenblit AB. Vychislitelnie Metodi Konstruirovaniya Lekarsv. Riga: Zinatne; 1978.

70. Golovkin BN. Istoriya Introdukcii Rasteniy v Botanicheskyh Sadah. Moscow: MGU; 1981.

71. Golosnickiy AK. Profilaktika Otravleniya Zhivotnikh Rastitelnimi Yadami. Moscow: Kolos; 1979.
72. Goncharova OA. Narodnaya Meditsyna Gornogo Altaya. Gorno-Altaisk: Jg-SumerBeluha; 2005.

73. Gorchakov VD, Sergienko VI, Vladimirov VG. Selektivnie Gemosorbenti. Moscow: Meditsyna; 1989.

74. Gisunova SV, Demina NS. Vodorosli Producenti Toksicheskyh Veschestv. Moscow: Nauka; 1974

75. Gorialev MI. Efirnie Masla Flori SSSR. Alma-Ata: Izd-vo AN Kazakhskoy SSR; 1952.

76. Goryaev M, Pliva I. Metody Issledovaniya Efirnyh Masel. Alma-Ata: Izd-vo AN Kazakhskoy SSR; 1962.

77. Grischin AG. Narkotrafik - problema naschego vremeni. In: Deyatelnst Pravoohranitelnikh Organov i Specialnikh Sluzhb v Sfere Protivodeistviya Nerakonnomu Oborotu Narkotikov: Voprosi Organizacii, Koordinacii, Vzaimodeistvia i Mezhdunarodnogo Sotrudnichestva. Materialy Mezhdunarodnoi Nauchno-Prakticheskoi Conferencii 15-16 Dekabrya 2010 Goda. Chast 1. Gosudarstvennaya Politika, Vzaimodeistvie Organov, Obschestvenno-Gosudarstvennoe Partnerstvo i Mezhdunarodnoe Sotrudnichestvo V Sfere Protivodeistviya Nezakonnomu Oborotu Narkotikov. Murino: SZ IPK FSKN Rossii; 2010. p. 27-43.

78. Grischenko EV. Chto Nuzhno Znat O Yadovitych Ribah Tadzhikistana. Duschanbe: Donisch; 1984.

79. Grummer G. Vzaimnoe Vliyanie Vysschikh Rasteniy - Allelopatiya. Moscow: Izd-vo Inostrannoy Literatuty; 1957.

80. Gudman M, Morhanz F. Orhanicheskie Molekuly v Deystvii. Moscow: Mir; 1977.

81. Gusinin IA. Toksikologiya Yadovitykh Rasteniy. Moscow: Selkhozizdat; 1951.

82. Davidenkov SN. Problema Polimorfizma Nasledstvennikh Boleznei Nervnoi Sistemi. Kliniko-Geneticheskoe Issledovanie. Leningrad: Izd-vo Vsesosouznogo Instituta Eksperimentalnoi Meditsyny; 1934

83. Davidenkov SN. Evolucionno-Geneticheskie Problemi Nevropatologii. Leningrad: GIDUV; 1947.

84. Davidenkova EF. Bolezn Dauna. Leningrad: Meditsyna; 1966.

85. Davidenkova EF, Liberman IS. Klinicheskaya Genetika. Leningrad: Meditsyna; 1975.

86. Davitaschvili LSch. Kurs Paleontologii. Moscow, Leningrad: Gos. Izd-vo Geologicheskoi Literaturi; 1949

87. Davitaschvili LSch. Prichini Vimiraniya Organismov. Moscow: Nauka; 1969.

88. Danilin AG. LSD. Gallicinogeni, Psikhodelia i Fenomen Zavisimosti. Moscow: Tsentropolygraf; 2001.

89. De Crui P. Borba s Bezumiem. Moscow: Izdvo Inostrannoy Literury; 1960.

90. Demchuk SD. Obschestvo potrebleniha, deviantnoe povedenie i ugrozi blagopoluchi $\mathrm{u}$ prirodi. Biosfera. 2012;(4(2)):217-24.

91. Demyanov NYa, Nilov VI, Vilyams VV. Efirnie Masla. Ikh Sostav i Analiz. Moscow, Leningrad: Gossudarstvennoye KhimikoTekhologicheskoe Izd-vo; 1933. 
92. Dimitrov S, Zhmurov A, Antonov S. Diagnostika Otravleniy Zhivotnykh. Moscow: Agropromizdat; 1986.

93. Dinamika Populacionnikh Genofondov pri Anthropogennikh Vozdeistviyakh. Moscow: Nauka; 2004.

94. Dmitriev MT, Rastyanniakov EG, Malicheva AG. Tabachniy dim. Gigienichescaya ocenka organicheskikh veschestv $\mathrm{v}$ tabachnom dime. Zhizn i Bezopasnost 1998;(2-3):452-4.

95. Dragavzev VA, Chesnokov YuV. Perspektivi geneticheskikh experimentov po udaleniju gashishnosti u konopli. Zhizn Bezopasnost Ekologiya. 2009;(3-4):41-5.

96. Drozhzhin AI, Ivanenkov VV, Mityagin SA, Krisanov VP. Organizaciya sistemi monitoringa i kompleksnogo analiza narcosituacii v regione. In: Deyatelnost Pravoohranitelnikh Organov i Specialnikh Sluzb V Sfere Protivodeistviya Nezakonnomu Oborotu Narcotikov; Voprosi Organizacii, Koordinacii, Vzaimodeistviya i Mezhunarodnogo Prakticheskoi Konferenci 15-16 Dekabrya. 2010 God. Chast 1. Gosudarstvennaya Politika, Vzaimodeystvie Organov Vlasti, Obschestvenno-Gosudarstvennoe Partnerstvo I Mezhdunarodnoe Sotrudnichestvo V Sfere Protivodeystviya Nezaconnomu Oborotu Narkotikov. Murino: SZ IPK FSKA Rossii; 2011. p. 50-65.

97. Dudar AK. Yadovitie Rasteniya Lugov i Pastbisch. Moscow: Rosselkhozizdat; 1980.

98. Yevteev SP. Nezakonniy Oborot Narkoticheskikh Sredstv, Psikhotropnih, Silnodeystvujuschikh i Yadovitysh Veschesv. Entsyklopedicheskiy Slovar-Spravochnik dla Operativnikh i Sledstvennikh Podrazdeleniy. Moscow: FKU NIZ FSKN Rossii; 2015.

99. Yesakov VD, Levina ES. Stalinskie «Sudi Chesti»: «Delo "KP"». Moscow: Nauka; 2005.

100. Yefremov IA. Tafonomia i Geologisskaya Letopis. Kniga 1. Zahoronenie Nazemnikh Form v Paleozoe. Moscow; 1950.

101. Zhidkie Kristalli v Medicine. Kiev: Naukova dumka; 1980.

102. Zhirnov E. Delo o devyati bankah morfiya. Kommersant Dendi. 2012;39(896):49-56.

103. Zhmurov VA. Psikhopatologiya. Chast 2. Psikhopatologicheskie Sindromi. Irkutsk: Izd-vo Irkutskogo Universiteta; 1994.

104. Zhukovskiy PM. Kulturnie Rasteniya I Ikh Sorodichi. Sistematika, Geografiya, Citogenetica, Immunitet, Ekologiya, Proishozhdenie, Ispolzovanie. Leningrad: Kolos; 1971.

105. Zazulind G. Soyuz «Za Obschetvo Bez Narcotikov». In: Antinarkoticheskaya Politika: Schvedskiye Otvety na Rossiyskiye Voprosi. Saint Petersburg: SPbGU; 2008. p. 137-70.

106. Zakrevskiy VV. Geneticheski Modificirovannie Istochniki Pischi Rastitelnogo Proishozdeniya. Prakticheskoe Rukovodstvo Po Sanitarno-Epidemiologichskomu Nadzoru. Saint Petersburg: Dialekt; 2006.

107. Zaugolnkov SD, Kochanov MM, Loyt DD, Stavhansky II. Ekspressnie Metodi Opredeleniya Toksichnosti i Opasnosti Khimicheskikh Veschestv. Leningrad: Meditsyna; 1978.
108. Zaharov VV. Zhabiy Yad. Kishinev: Kartya Moldovenyaske; 1978.

109. Zacepilova TA, Paschin UV. Mutagenniy Potencial Lekarstvennikh Sredstv. Moscow: Nauka; 1980.

110. Zeigarnik BV. Patopsikhologiya. Moscow: MGU; 1976.

111. Zelenina ON. O beznarcotichnosti sortov konopli, vnesennikh v Gosudarstvenniy reestr selekcionnikh dostizheniy. Zhizn Bezopasnost Ekologiya. 2009;(3-4):37-40.

112. Zolotnickaya SJa. Lekarstvennie Resursi Flori Armenii. T. 1. Yerevan: Izd-vo AN Armyanskoi SSR; 1958.

113. Zubin BI. Fitonematodi Lekarstvennogo Maka Virgizii. Frunze: Ilim; 1969.

114. Ivanenko EF. Biokhimiya Mozga Pri Narkoze. Leningrad: Meditsyna; 1972.

115. Ivanich Ju. Narcotiki i Terrorizm. Pautina Zla. Moscow: Veche; 2005.

116. Ivanov VP. Pauki, Ikh Stroenie, Obraz Zhizni I Znachenie Dlya Cheloveka. Leningrad: LGU; 1965.

117. Ivanov VP. Sostoyanie i nasuschnie voprosi kontrolya za oborotom narcotikov v RF. Zhizn Besopasnost Ekologiya. 2009;(1-2):37-41.

118. Ivanov VP. O novoi paradigme antinarcoticheskoi politiki, orrazhau schei nasilie i realizujuschei pravo na razvitie. Biosfera. 2013;5(2):234-6.

119. Iluk PD, Krupizkiy EM, Torlan MN. Fenomenologia peredozirovok i potrebiteley opiynikh narkotikov. Teoriya i praktica protivodeistviya nezakonnomu oborotu narkotikov. In: Meteriali Vserossiskoy Nauchno-Prakticheskoi Conferencii 15-16 Dekabrya 2009 G. Chast 1. Murino: SZ IPK FSKN Rossii; 2011. p. 167-8.

120. Issledovaniya po Genetike Psikhicheskikh Bolezney. Doklad Nauchnoy Gruppy VOZ. Vsemirnaya Organizaciya Zdravoohraneniya. Moscow: Meditsyna; 1967.

121. Kabanov MM. Reabilitaciya Psikhicheskikh Bolnih. Leningrad: Meditsyna; 1985.

122. Kabanov MM. Schizofreniya i nevrozi problema etiketirovaniya. In: Diagnistika i Reabilitatsiya v Psikhiatrii. Saint Petersburg: 1993. p. 22-30.

123. Kabanov N. Rol Nasledstvennosti v Etiolologii Boleznei Vnutrennikh Organov. Moscow: Tipo-Litografiya GI Prostakova; 1899.

124. Kaymak EV. Ugrozi narcotizma na kriticheski vazhnikh i potencialno opasnikh obektah infrastrukturi Rossii. Biosfera. 2012:4(2):225-33.

125. Kalinnikova VD. Protivoopuholevie Svoystva Zhgutikovogo Prosteishego Trypanosoma Cruzi. Tula: Gris IK; 2004.

126. Karpenko YuA, Sjrenko LA, Ozlovskiy VM, Lukina LF. Toksini Sine-Zelenikh Vodorosley i Organism Zhivotnogo. Kiev: Naukova dumka; 1977.

127. Kerpov YaS, Chistyakov IN. K voprosu o kontrole za oborotom silnodeystvuiuschikh khimicheskikh veschestv, ne yavlyauschihsya precursarami, lekarstvennimi sredstvami i ne vkluchennimi v sostav pischevikh ili biologicheski aktivnikh dobavok (na primiri khimicheskogo 
veschestva

«gamma-butirolaktona»).

In:

Deiatelnost Pravoohranitelnikh Organov

Specialnikh Sluzhb V Sfere Borbi S Nezakonnim

Oborotom Narkotikov. Materialy Vserossiyskoy

Nauchno-Prakticheskoi Conferencii 18-

19 Dekabria 2008 G. Chast 3. Raskritiei

Rassledovanie Prestupleniy v Sfere Nezakonnogo

Oborota Narkotikov: Sostoyanie I Perspektivi.

Murino: SZ IPK FSKN Rossii; 2009. p. 25-40.

128. Kasenov K. Zmeinie Yadi i Reaktivnost

Organizma. Alma-Ata: Kazahstan; 1977.

129. Kvitko KV. K genetike pola i konopli

(Cannabis sativa L.). In: Issledovaniya Po Genetike.

Leningrad: LGU; 1961. p. 106-15.

130. Kiselev AS, Sochneva ZG. Zakonomernosti

Nachala, Techeniya i Iskhodov Osnovnikh

Psikhicheskikh Zabolevaniy (Statisticheskoe

Issledovanie). Riga: Zinatne; 1988.

131. Klinicheskaya Toksikologiya Detey i

Podrostkov. Saint Petersburg: Intermedika; 1998.

132. Kliot EA. Pochem Putevka v Zhizn

(Linteraturnaya Zapis L.N. Anikina). Saint

Petersburg: Dmitriy Bulavin; 2008.

133. Klueva NG, Roskin GI. Bioterapiya

Zlokachestvennikh Opuholey. Moscow: Izd-vo

AMN SSSR; 1946.

134. Klueva NG, Roskin GI. Problema

Protivorakovikh Antibiotikov. Obratnoe Razvitie

Zlokachestvennikh Opuholey Pod Vliyaniem

Faktorov Mikrobnogo Proishozhdeniya. Moscow:

Institut Vaktsin im. PA Tarasevicha; 1957.

135. Komitet ekspertov VOZ po lekarstvennoy zavisimosti. 20-y doklad. Vsemirnaya Organizaciya Zdravoohraneniya. Seriya tekhicheskikh dokladov. N 551. Vsemirnaya Organizaciya Zdravoohraneniya. Moscow: Meditsyna; 1975

136. Komitet Ekspertov VOZ po Lekaestvennim

Sredstvam, Vizivauschim Zavisimost. 14-Y Doklad. Vsemirnaya Organizaciya Zdravoohraneniya. Seriya Tekhicheskikh Dokladov. N 312. Vsemirnaya Organizaciya Zdravoohraneniya. Moscow: Meditsyna; 1966.

137. Kondrachenko VT. Deviantnoe Povedenie

Podrostkov: Sotsyalno-Psikhologicheskie i

Psigologicheskie Aspekti. Minsk: Belarus; 1988.

138. Konechniy R, Biuhal M. Psikhologia V Medicine. Praha: Avicenum; 1974.

139. Kornilov KN. Uchenie o Reaktsiyakh Cheloveka s Psikhologicheskoy Tochki Zreniya (Reaktologiya). Moscow: Gosizdat; 1921.

140. Kozarev SJu. Yadovitie veschestva kak sredstvo sovershenuya protivopravnikh deyaniy. In: Teoriya i Praktika Protivodeistviya Nezakonnomu Oborotu Narkotikov. Materialy Vserossiskoy Nauchno-Prakticheskoi Conferencii 15-16 Decabrya 2009 G. Chast 2. Murino: SZ IPK FSKN Rossii; 2011. p. 168-72.

141. Kostuchenko AL, Dyachenko PK. Vnutrivenniy narcoz i antinarcotiki. Saint Petersburg: DEAN; 1998.

142. Kocherina NV, Dragavtsev VA. Vvedenie v Teoriu Ekologo Geneticheskoy Organizacii Poligennikh Priznakov Rasteniy I Teorii Selekcionnikh Indeksov. Saint Petersburg: Salezianskiy Centr «Don Bosco»; 2008. 88 s.
143. Koen SchT, Veiss R. Zloupotreblenie narcoicheskimi veschestvami i psikhicheskie zabolevaniya. In: Narcologia. Moscow: Binom; 1998. p. $275-85$.

144. Kraft-Ebing R. Uchebnik Psikhiatrii. 3-e Russkoe Izdanie. Saint Petersburg: Izdanie KL. Rikkera; 1897.

145. Krechetovich LM. Yadovitie Rasteniya, Ikh Polza i Vred. Moscow, Leningrad: Selhozizdat; 1931.

146. Kroncovskiy AA. Nasledstvennost I Konstituciya. Praktichescoe Posobie K Issledovaniju Patologichescoi Nasledstvennosti I Konstitucii Cheloveka. Kiev: Gosudarstvennoye Izdatelstvo Ukraini; 1925.

147. Kupriyanov VV, Borodin YuI, Karaganov YaL, Virenkov YuE. Mikrolimfologiya. Moscow: Meditsyna; 1983.

148. Kupriyanov VV, Karaganov YaL, Kozlov VI. Microcirculatornoe Ruslo. Moscow: Meditsyna; 1975.

149. Kuptsov AI. Vvedenie v Geografiu Kulturnykh Rasteniy. Moscow: Nauka; 1975.

150. Kureniye i Zdorovie (Materialy MAIR). Moscow: Meditsyna; 1989.

151. Lazarev NV. Narkotiki. Leningrad: Izdvo Instituta Gigieni Truda i Professionalnikh Zabolevaniy Lengorzdravotdela; 1940.

152. Lazarev NV. Obschee Uchenie o Natcoticah i Narcoze. Pyat Publichnikh Lektsiy. Leningrad: Izd-vo Voenno-Medicinskoy Akademii; 1958.

153. Lazjursciy AF. Classificaciya Lichnostei. Petrograd: Gosudarstvennoye Izd-vo; 1922.

154. Laine M. Criminologiya I Sotsyologiya Otclonennogo Povedeniya. Helsinki: Centr Obucheniya Turemnikh Sluzhaschih; 1994.

155. Lakin KM, Krilov YuF. Biotrasfotmaciya Lecarstvennikh Veschestv. Obschie Voprosi. Moscow: Meditsyna; 1981.

156. Lacoshina ND, Trunova MM. Nevrozi I Nevroticheskoe Razvitije Lichnosti. Clinica I Lechenie. Moscow: Meditsyna; 1994.

157. Lapin IP. Lichnost I Lekarstva. Vvedenie V Psikhologiju Farmacoterapii. Saint Petersburg: DEAN; 2001.

158. Lafickaya NV. Fenomen Agressii u Vida Homo Sapiens. Pytki i Kazni. Saint Petersburg: Nevskaya Zhemchuzhina; 2006.

159. Lebedinskiy MS, Myasischev VN. Vvedeniye v Medicinskuju Psikhologiyu. Leningrad: Meditsyna; 1966.

160. Liljin ET, Trubnikov VI. Valukov MM. Vvedeniye v Sovremennjuj Farmakogenetiku. Moscow: Meditsyna; 1984.

161. Listov MV. Khimicheskaya Zaschita u Chlenistonogikh i Izmenchivost Organizov. Leningrad: Nauka; 1989.

162. Losev IV. Kompleksnoye issledovanie i ocenka narcosituacii (monitoring). In: Teoriya i Praktika Protivodeystviya Nezaconnomu Oborotu Narkotikov. In: Materialy Vserossiskoy NauchnoPrakticheskoi Konfarancii 15-16 Dekabria 2009 G. Chast 2. Murino: SZ IPK FSKN Rossii; 2010. p. $7-13$.

163. Luzhnikov EA. Klinicheskaya Toksikologiya. Moscow: Meditsyna; 1994. 
164. Lubchenko PN. Intoksikacionie Zabolevaniya Organov Pischevareniya. Voronezh: Izd-vo Voronezhskogo Universiteta; 1990.

165. Majskiy AI, Vedernikova NN, Chistyakov VV, Lakin VV. Biologicheskie Aspekti Narcomanii. Moscow: Meditsyna; 1982.

166. Makkusik VA. Nasledstvennie Priznaki Cheloveka. Moscow: Meditsyna; 1976.

167. Macsimov MT. Zaschita ot Silnodeystvujuschikh Yadovitikh Veschestv. Moscow: Energoatomisdat; 1993.

168. Malseva MM, Kotov VV. Opasnie Deystviya Psikhicheskikh Bolnih. Psikhopatologicheskie Mehanizmi i Profilactica. Moscow: Meditsyna; 1995.

169. Maluhin DM. Necotorie aspecti racionalnogo ispolzovaniya rasteniy roda Cannabis, a tagzhe meri, sposobstvujuschie effectivnisti protivodeystviu ikh nepravilnigi cultivirovaniya na territorii Rossiscoy Federacii. Zhizn Bezopasnost Ekologiya. 2011;(1-2):85-9.

170. Malyarevskaya AYa. Obmen Veschestva Ryb v Usloviyah Antropogennogo Evtrofirovaniya Vodoemov. Kiev: Naukova Dumka; 1979.

171. Marikovskiy PI. Tarantul i Karakurt. Morfologiya, Biologiya, Yadovitost. Frunze: Izdvo AN Kirgizskoy SSR; 1956.

172. Matveev VF. Psikhicheskie Naruscheniya Pri Defectah Zreniya i Sluha. Moscow: Meditsyna; 1987.

173. Matveev VA, Razumov AN. Patologicheskaya Fiziologiya Cheloveka i Vosstanovitelnaya Meditsyna. Moscow: GEOTAR Meditsyna; 1999.

174. Maschkozev MF. Khimiya Tabaka. Moscow: Pischevaia Promischlennost; 1971.

175. Medvedev YuA. Tanatologicheskiy Analiz v Patologoanatomicheskoi Praktike. Saint Petersburg; 2005.

176. Mezhdunarodnaya Klassifikaciya Boleznei (Desyatiy Peresmotr). Klassifikaciya Psikhicheskikh i Povedencheskikh Rastroistv. Klinicheskie Opisaniya I Ukazaniya Po Diagnostike. Saint Petersburg: Adis; 1994.

177. Merfi EA, Cheiz GA. Osnovi MedikoGeneticheskogo Konsultirovaniya. Moscow: Meditsyna; 1979.

178. Mehanizmi Vozdeystviya Zootoksinov. Mezhvuzovskiy Sbornik. Gorkiy: 1975.

179. Mehanizmi Vozdeistviya Zootoksinov. Mezhvuzvskiy Sbornik. Gorkiy; 1977.

180. Mehanizmi Vozdeystviya Zootoksinov. Mezhvuzvskiy Sbornik. Gorkiy; 1978.

181. Mehanismi Vosdeystviya Zootoksinov. Mezhvuzvskiy Sbornik. Gorkiy; 1980.

182. Mehanismi Vosdeystviya Zootoksinov. Mezhvuzvskiy Sbornik. Gorkiy; 1981.

183. Mikava AG. Narkokontrol v LPU. Rabota nad Oshibkami Neobhodima. Meditsyna Peterburga. 2010;(1(308)):2-3.

184. Miller Dzh, Galanter E, Pribram K. Plani I Struktura Povedeniya. Moscow: Progress; 1965.

185. Milstein GI, Spivak LI. Psikhomimetiki. Leningrad: Meditsyna; 1971.

186. Minukov D, Teplov E, Teplova N. Pyanstvo, alkogolizacuya, politika i nacionalnaya bezopasnost. Zhizn i Bezopasnost. 1999;(3-4):77-93.
187. Molokovskiy DS, Grigoryev VA. Prinuditelnoe lecheniye bolnykh opiynoy narkomaniyey. Farmakoterapevticheskie vozmozhnosti dokazatelnoi narcologii dlia uderzhaniya bolnikh v lechebno-reabilitacionnikh programmah. In: Deyatelnost Pravoohranitenikh Organov i Specialnikh Sluzhb v Sfere Protivodeistviya Nezakonnomu Oborotu Narkotikov: Voprosi Organizacii, Koordinacii, Vzaimodeystviya. Materialy Mezhdunarodnaya Nauchno-Prakticheskoy Konferencii 15-16 Dekabrya 2010 Goda. Chast 1. Gosudarstvennaya Politika, Vzaimodeystvie Organov Vlasti, ObschestvennoGosudarstvennoe Partnerstvo I Mezhdunarodnoe Sotrudnichestvo v Sfere Protivodeystviya Nezakonnomu Oborotu Narkotikov. Murino: SZ IPK FSKN Rossii; 2011. p. 146-57.

188. Mosunov SA, Cacenko LV. Izuchenie chastoti dvoynykh gamet jusortov tabaca kollekcii VNIITTI. In: Tezisy Dokladov II Vavilovskoy Mezhdunarodnoy Konferencii 26-30 Noyabriya 2007 g. «Genetiheskiye Resursy Kulturnykh Rasteniy v XXI Veke. Sostoyanie, Problemi, Perspektivi». Saint Petersburg: VIR; 2007. p. 314-5. 189. Muceniece AYa. Onkotropism Virusov i Problema Viroterapii Zlokachestvennikh Opuholey. Riga: Zinatne; 1972.

190. Nadezhdin AV. Toksikomaniya, Vizvannaya Letuckhimi Juglevodorodami: Epidemiologiya, Klinika, Lechenie. Moscow: Medpraktika; 2004. 191. Narkologiya. Moscow: Binom; 1998.

192. Nezakonniy Oborot Narkotikov. Globalie Tendencii I Problemi. Sbornik Dokladov Mezhdunarodnogo Komiteta po Kontrolu nad Narkotikami. Moscow: Astreya-Tsentr; 2007.

193. Nikitin AV, Scherbich AN, Scherbich LA. Monitoring V Sfere Oborota Narkotikov. Saint Petersburg; 2009.

194. Nikitin AV, Scherbich AN, Scherbich LA. Normativno-Pravovoye Obespecheniye Profilaktiki Vozniknoveniya Chrezvichainikh Situatsiy, Svyazannykh s Nezakonnym Oborotom Narkorikov. Saint Petersburg; 2010.

195. Obezbolivaniye pri Rake. Geneva: VOZ; 1988.

196. Obespecheniye Ekologichskoy Bezopasnosti pri Ispolzovanii Geneticheski Modificirovannykh Organizmov. Sbornik Materialov Kruglogo Stola Vserossiyskoy Konferencii po Ekologicheskoy Bezopasnosti (4-5 Iunya 2005 g). Moscow; 2002.

197. Obraschenie k Roditelyam i Uchitelyam ob Opasnosti Narkomanii. Zhizn i Bezopasnost. 1998;(4):369.

198. Obuhovskiy K. Psikhologiya Vlecheniy Cheloveka. Moscow: Progress; 1971.

199. Ozerezkovskiy DS. Navyazchevie Sostoyaniya. Moscow: Medgiz; 1950.

200. Oygenziht VA. Volya i Voleizyavlenije (Ocherki Teorii, Filosofii I Psikhologii Prava). Duschanbe: Donisch; 1983.

201. Oksengendler GI. Antidoty Visokotoksichnikh Veschestv. Leningrad; 1979.

202. Oksengendler GI. Yady i Protivoyadiya. Leningrad: Nauka; 1982.

203. Oksengendler GI. Yady i Protivoyadiya. Problemi Khimicheskoy Opasnosti. Saint Petersburg: Nauka; 1991. 
204. Onkotropism Virusov. Riga: Zinatne; 1969. 205. Operaciya «Doping». Zhizn i Bezopasnoat. 1999;(3-4):216-9.

206. Orlov BN, Gelaschvili DB. Zootoksinologiya (Yadovitie Zhivotnie i Ikh Yadi). Moscow: Visshaya Shkola; 1985.

207. Orlov BN, Gelaschvili DB, Ibragimov DN. Yadovitie Zhivotnie i Rasteniya SSSR. Moscow: Vyshaya Shkola; 1990.

208. Orlov BN, Gelaschvili DB, Kuznecova MA. Yadovitie Bezpozvonochnie i Ikh Yadi. Gorkiy: 1981.

209. Orlov BN, Gelascjvili DV. Zootoksinologiya (Yadovitie Zhivotnie i Ikh Yadi). Moscow: Vyschaya Skola; 1985.

210. Pavlovskiy EN. K voprosu o stroenii yadovitykh zhelez sustavchatonogikh. Trudy Sankt-Petersburgskogo Obschestva Yestestvoispitateley. 1912-1913;43(2):1-190.

211. Pavlovskiy EN. K stroeniyu i razvitiyu yadovitykh zhelez skorpionov. Russkoye Entomologicheskoye Obozreniye; 1914;14(1):57-69.

212. Pavlovskiy EN. Rukovodstvo po Parazitologii Cheloveka s Ucheniem o Perenoschikakh Transmissivnikh Bolezney. Tom 1. Moscow, Leningrad: Izd-vo AN SSSR; 1946.

213. Pavlovskiy EN. Rukovodstvo Po Parazitologii Cheloveka s Ucheniem O Perenoschikakh Transmissionnykh Bolezney. Tom 2. Moscow, Leningrad; Izd-vo AN SSSR; 1948.

214. Pavlovskiy EN. Prirodnaya Ochagovost Transmissionnykh Bolezney v Svyazi s Landschaftnoy Epidemiologiyey Zooantroponozov. Moscow, Leningrad: Nauka; 1964.

215. Palilova AN. Vnekhromosomnaya Nasledstvennost. Minsk: Nauka i Tekhika; 1981.

216. Park DV. Biokhimiya Chuzherodnykh Soyedineniy. Moscow: Meditsyna; 1973.

217. Pedli T. Gidrodinamika Krupnykh Krovenosnikh Sosudov. Moscow: Mir; 1983.

218. Petrovich SV. Mikotoksikozi Zhivotnykh. Moscow: Rosagropromizdat; 1991.

219. Poznanskiy AS. Vliyaniye Kofeina na Gallucinatsii. Sovezkaya Psikhonevrologiya. 1936;(7):18-22.

220. Popov YuV. Profilaktika i Korrekciya

Samorazruchauschego Povedeniya u Podrostkov.

Posobiye dlya Vrachey. Saint Petersburg; 1995.

221. Potapov A. O nashikh yadovitykh zhivotnykh. Zhizn i Bezopasnost. 1999;(3-4):441-51.

222. Potapov LP. Okhotnichiy Promisel Altaitsev (Otrazheniye Drevneturkskoy Kulturi v Tradicionnom Okhotnichyem Promysle Altaitsev). Saint Petersburg; 2001.

223. Poshivalov VP. Eksperimentalnaya Psikhofarmakologiya Agressivnogo Povedeniya. Leningrad: Nauka; 1986.

224. Primrojuz S, Tvaimen R. Genomika. Rol v Medicine. Moscow: Binom; 2008.

225. Protivorakoviy Antibiotik Krucin. Moscow: MGU; 1968.

226. Radkevich PE. Veterinarnaya Toksikologiya. Moscow: Kolos; 1972.

227. Rajut ChP, Stefen A, Kosovski B. Vnutrijutrobnie posledstvya. In: Narkologiya. Moscow: Binom; 1998. p. 257-74.
228. Revunenkova YeV. Ritualnosimvilicheskaya rol betelya $\mathrm{V}$ malaysko indoneziscom regione $\mathrm{v}$ proschlom i nastoyaschem. In: Nauchnie Issledovaniya I Muzeinie Proekti Muzeya Antropologii i Etnografii Im. Petra Velikogo (Kunstkamera) RAN v 2008 g. Radlovskiy Sbornik. Saint Petersburg: Muzey Antropologii i Etnografii RAN; 2008. s. 459-63.

229. Renyar P. Umstvennie Epidemii. Demonism, Isteriya, Gipnotizm i Maniya Velichiya. Moscow: Emergency Exit; 2004.

230. Snezhnevskiy AV, ed. Rukovodstvo po Psikhiatrii. Tom 1. Moscow: Meditsyna; 1983.

231. Snezhnevskiy AV, ed. Rukovodstvo po Psikhiatrii. Tom 2. Moscow: Meditsyna; 1983.

232. Rusalov VM. Biologicheskie Osnovi Individualnikh Psikhologicheskikh Razlichiy. Moscow: Nauka; 1979.

233. Rutovskiy BN. Efirnie Masla. Tom 1. Sposobi Poljucheniya Efirnikh Masel i Ikh Analiz. Moscow, Leningrad: Gosudarstvennoye Izd-vo Selskohozyastvennoy i Kolhozno-Kooperativnoy Literaturi; 1931.

234. Ribalskiy MI. Illuzii I Gallucinacii. Sistematika, Semiotika, Nozologicheskaya Prinadlezhnost. Baku: Maarif; 1983.

235. Sakevich AI. Ekzometaboliti Presnovodnikh Vodorosley. Kiev: Naukova Dumka; 1985.

236. Sapin MR, Borziak YeI. Vneorgannye Puti Transporta Limfy. Moscow: Medcina; 1982.

237. Safaev RD, Zaridze DG, Belickiy GA, Dzhordzhevi M, Brunneman K. Kancerogennie veschestva $v$ tabake i dime sigaret: policiklicheskie aromaticheskie uglevorodi, metalli, pesticidi. Eksperimentalnaya Onkologia. 1992;(3):25-9.

238. Safiyanov VA, Medvdev VN. K voprosju o protivodeystvii nezakonnomu oborotu narcoticheskikh sredstv, izgotavlivaemikh iz semyan pischevogo maka. In: Deyatelnost Pravoohranitelnikh Organov i Specialnikh Sluzhb v Sfere Borby s Nezakonim Oborotom Narkotikov. Materialy Vserossiskoy Nauchno-Prakticheskoy Konferencii 18-19 Dekabria 2008 Goda. Chast 3. Raskritie i Issledovanie Prestupleniy v Sfere Nezakonnogo Oborota Narkotikov. Murino: SZ IPK FSKN Rossii; 2009. p. 19-21.

239. Saharov GP. Metodologiya Patologii. Moscow; 1934.

240. Svetlov PG. Teoriya kriticheskikh periodov razvitiya i ee znachenie dlya ponimaniya principov deistviya sredi na ontogenez. In: Voprosi Tsytologii i Obschey Fiziologii. Moscow, Leningrad: Izd-vo AN SSSR, 1960. p. 263-85.

241. Sidhakin VG. Vliyanie Globalnikh Ekologicheskikh Faktorov na Nervnuju Sistemu. Kiev: Naukova Dumka; 1986.

242. Sinitskiy VN. Depressovnie Sostohaniya (Patofiziologicheskaya Harakteristika, Klinika, Lechenie, Profilaktika). Kiev: Naukova Dumka; 1986.

243. Sinskaya EN. Istoricheskaya Geografiya Kulturnoy Flory (Na Zare Zemledeliya). Leningrad: Kolos; 1969.

244. Sirenko LA, Gavrilenko MA. «Cvetenie» Vodi I Evtrofirovanie (Metod Yego Ogranicheniya i Ispolzovanie Sestona). Kiev: Naukova Dumka; 1978. 
245. Sirenko LA, Kozickaya VN. Biologicheski Aktivnie Veschestva Vodorosley i Kachestvo Vody. Kiev: Naukova Dumka; 1988.

246. Slepyan SN (Otets Sergiy). O Piyanstve. Saint Petersburg; 1886.

247. Slepyan SN (Otets Sergiy). Beseda o Tabake. Saint Petersburg: Tipografiya PP Soykina; 1887.

248. Slepyan SN (Otets Sergiy). Pouchenie Protiv Piyanstva. Moscow: Otdel Rasprostraneniya Duhovno-Nravstvennikh Knig; 1891.

249. Slepyan SN (Otets Sergiy). PiyanstvoOkayanstvo. Saint Petersburg: Tipografiya AV Pozharovoy; 1893.

250. Slepyan EI. K voprosu ob izuchennosti rasteniy flori Rossii, soderzhaschikh psikhotropnie veschestva (v svyazi s problemoi narkomanii, obuslovlennoy potrebleniem fitonarcoticheskikh sredstv). In: Deyatelnost Pravoohranitelnikh Organov i Specialnikh Sluzhb v Sfere Borbi s Nezakonnim Oborotom Narkotikov. Materialy Vserossiskoy Nauchno-Prakticheskoy Konferencii 18-19 Dekabrya 2008 G. Chast 1. Murino: SZ IPK FSKN Rossii; 2009. p. 65-87.

251. Slepyan EI. Kriterii nenasiliya i nasiliya i intellektualnoe razvitie. In: VII Mezhdunarodniy Kongress Mezhdunarodnoy Assotsyatsyi Rabotnikov Prosvescheniya za Mir vo Vsem Mire 22-27 Maya 1994 g. Tezisi. Chast 1. Saint Petersburg. p.152-62.

252. Slepyan EI. Magnoliofiti i ikh psikhotropnoe vozdeistvie. In: Teoriya i praktika protivodeystviya nezakonnomu oborotu narkotikov: Materialy Vserossiysky Nauchno-Prakticheskoy Konferencii 15-16 Dekbrya 2009 G. Chast 1. Murino: SZ IPK FSKN Rossii; 2010. p. 49-61.

253. Slepyan EI. Premorbidnaya diagnostika pri ekologicheskoy expertize - osnova kontrolya za sostoyaniem bioti. In: Problemi Donozologicheskoy i Gigienicheskoy Diagnostiki. Materialy Nauchnoy Konferentsyi 23-25 Maya 1989 g. Leningrad: Nauka; 1989. p. 49-51.

254. Slepyan EI. Sistema patogennikh agentov, faktorov riska i patotropnikh situaciy $\mathrm{v}$ aspekte yestestvenno-nauchnoy kartini Mira. In: Biologicheskaya Indikaciya v Antropoekologii. Materialy Vtorogo Vsesouznogo Soveschaniya po Kosmicheskoy Antropoekologii 2-6 Iunya 1984 G. Leningrad: Nauka; 1984. p. 6-62.

255. Slepyan EI. Strategii ozeleneniya, kategorii rasteniy-ozeleniteley i problemi sohraneniya i ozdorovleniya gorodskoy prirodnoy sredi. In: Ozelenenie, Problemi Fitogigieni i Okhrana Gorodskoy Prirodnoy Sredi. Leningrad: ZIN AN SSSR; 1984. p. 138-230.

256. Slepyan EI. Suschnost ekologii, ekologicheskiy terrorizm i ekologicheskaya informaciya, imeyuschaya yuridicheskoye znacheniye. In: Pravovye Aspekty Obespecheniya Ekologicheskoy Bezopasnosti. Materialy EkologoPravovogo Foruma 28-29 Oktyabrya 2004 g. Moscow: Izdatelskiy Dom Zhizn Bezopasnost Ekologiya; 2004. p. 9-14.

257. Slepyan EI. Ekologicheskaya opasnost, ekologicheskaya bezopasnost i sozdanie sistem ekologicheskoy zaschiti. In: Ekologicheskaya Adaptatsiya Obschestva na Postsovetskom
Prostranstve. Moscow: Mezhdistsyplinarniy

Institut Ekologicheskikh Proyektov; 2000. p. 14-27.

258. Slepyan EI. Ekologicheskiy risk. Regionalnaya Ekologiya. 2002;(1-2):62-82.

259. Slepyan EI. Ekologicheskiy terrorizm (predposilki i sistema). In: Trudy Devyatoy Vserossiskoy Nauchno-Prakticheskoy Konferencii «Aktualnie Problemi Zaschiti I Bezopasnosti. Tekhicheskie Sredstva Protivodeystviya Terrorizmu i Oruzhie Neletalnogo Deystviya». Tom 1. Saint Petersburg: Nauchno-proizvodstvennoe Objedinenie Specialnikh Materialov; 2006. p. 73-98.

260. Slepyan EI. Ekologicheskiy terrorism kak osobaya kategoriya terrorisma. In: Nauchnie Aspekti Ekologicheskikh Problem Rossii. Trudy 2 Vserossiyskoy Nauchnoi Conferencii 21-31 Maya 2006 G. Moscow: Meteoagentstvo Federalnoy Sluzhbi po Gidrometeorologii i Monitoringu Okruzhauschey Sredi; 2006. p. 239-43.

261. Slepyan EI. Ekologicheskiy terrorism: sushnost, sledstviya i usloviya ikh likvidacii. Zhizn i Bezopasnost. 2002;(1-2):277-83.

262. Slepyan EI. Ekologiya, ekologicheskaya opasnost, ekologicheskaya bezopasnost i kharakteristiki zhizni cheloveka. Povishenie kachestvazhizninaseleniya-vazhneishaya problema Rossiyskoy Federacii. In: Sbornik Nauchnikh Statey po Materialam 2 Mezhdunarodnogo Foruma «Kachestvo Zhizni: Sodruzhestvo Nauki, Vlasti, Biznesa i Obschestva». Moskva, 16-17 Noyabrya 2004 G. Chast 2. Moscow: Municipalniy Mir; 2005. p. 203-20.

263. Slepyan EI. Ekologicheskiy terrorism. Mashiny i Mekhanismy. 2009;(7):101-4.

264. Slepyan EI, Petrova NR. Vozmozhnie proyavleniya ekologicheskogo terrorisma $\mathrm{V}$ prostranstve sostavlyauschikh edinoy transportnoy sistemi i edinoy transportnoy sistemi v celom. In: Organizaciya Bezopasnosti Dorozhnogo Dvizheniya v Krupnikh Gorodah. Sbornik Dokladov Pyatoy Mezhdunarodnoy Konferencii. Saint Petersburg; 2002. p. 86-103.

265. Slepyan EI. Zigmund Freid i neyropsikhotropniy stimulator narkotik kokain - prirodnoe soedinenie, obrazuemoe rasteniyami - predstavitelyami rodov Cola i Erythroxylon. Antinarkoticheskaya Bezopasnost. 2014;1(4):94-6.

266. Smirnov VP, Fadeev MYu. Bolezni Nakopleniya (Tezaurismosi). Nizhniy Novgorod: Izd-vo NG MI; 2007.

267. Slepyan EI. Narcomaniya kak sotsyalnaya anomaliya i ee ekologicheskaya zavisimost. In: Slepyan EI, ed. Sbornik Nauchnikh Statey po Problemam Narkologii. Murino: SZ IPK FSKN Rossii; 2013. p. 49-181

268. Smirnov IV. Psikhoekologiya. Moscow; 2003.

269. Smit T, Smit K. Mehanizmi odratnoy svyazi v upravlenii povedeniem cheloveka. In: Chelovecheskiy Faktor. Tom 1. Moscow: Mir; 1991. p. 486-563.

270. Lein D et al., eds. Sovremennie Podkhody k Bolezni Dauna. Moscow: Pedagogika; 1951.

271. Sokolov VYe. Sistematika Mlekopitajuschih. Otryadi: Kitoobraznih, Hischnih, Lastonogih, Trubkozbih, Hobotnih, Damanov, Siren, 
Parnokopitnih, Mozolenogih, Neparnokopitnih. Moscow: Vysshaya Shkola; 1979.

272. Spesivtseva NA. Mikozi i Mikotoksikozi. Moscow: Kolos; 1964.

273. Stenko YuM, Mihelson DA, Rodnikov AV. Opasnye Morskiye Zhivotnye. Moscow: Pischevaya Promishlennost; 1984.

274. Stoliarov GV. K voprosu o kofeinomanii (teizme). In: Psikhicheskie Narusheniya pri Intoksikaciyah i Organicheskikh Porazheniyah Golovnogo Mozga. Moscow; 1963. p. 31-7.

275. Sultanov MN. Ukusi Yadovitikh Zhivotnih. Moscow: Meditsyna; 1977.

276. Suskov LI, Sazonova LA. Mutagennye effekty khimicheskikh soyedineniy u cheloveka. Uspekhi Sovremennoy Genetiki. 1983;(11): 93 132.

277. Suhanov SA. O gallucinatornikh navyazchivikh gallucinaciyah. Russkiy Vrach. 1904;(45):1503-7.

278. Talizin FF. Yadovitie Zhivotnye Sushi i Morya. Moscow: Znaniye; 1970.

279. Tambiev AH. Letuchiye Veschestva, Zapakhi i Ikh Biologicheskoye Znacheniye. Moscow: Znaniye; 1974. .

280. Tanasienko FS. Efirnye Masla. Soderzhanie i Sostav v Rasteniyah. Kiev: Naukova Dumka; 1985.

281. Tangiev BB. Kriminologiya Ekologicheskoy Prestuonosti (Kriminologicheskiy JugolovnoPravovoy Analiz). Saint Petersburg: GeoGraf; 2004.

282. Tangiev BB. Ekologicheskaya PrestjupnostOsnovnaya Ugroza Nacionalnoy Bezopasnosti Rossii (Jugolovno-Pravovoe Issledovanie). Saint Petersburg: GeoGraf; 2004.

283. Tashmukhamedov BA, Jusmanov PB. Neyrotoksini V Issledovanii Biologicheskikh Membran. Moscow: Vysshaya Shkola; 1991.

284. Tkachenko ES. Toksicheskoye Deystviye Mikroskopicheskikh Gribov. Moscow: Meditsyna; 1973.

285. Tomilin MG. Vzaimodeystviye Zhidkikh Kristallov s Poverhhnostyu. Saint Petersburg: Politekhika; 2001.

286. Tomilin MG, Nevskaya HE. Fotonika Zhidkikh Kristallov. Saint Petersburg: Izd-vo Politekhicheskogo Universiteta; 2011.

287. Troshin VD, Shibina LP. Teoreticheskie Metodologicheskie Osnovy Neyroprofilaktiki. Novosibirsk: Nauka; 1988.

288. Tischenko VP. Opredelitel Paukov Yevropeyskoy Chasti SSSR. Leningrad: Nauka; 1971.

289. Tutelyan VA, Kravchenko LV. Mikotoksini (Medicinskie i Biologicheskie Aspekti). Moscow: Meditsyna; 1985.

290. Tiukavkina NA, Litvinenko VZ, Shostakovskiy MF. Hromatografiya na Poliamidnikh Sorbentah v Organicheskoy Khimii. Novosibirsk: Nauka; 1973.

291. Ulitin AYu, Olushin VE, Ivanova NE. Cerebralnie limfomi, immunodeficitnie sostoyaniya, narkozavisimost. In: Teoriya i Praktika Protivodeystviya Nezakonnomu Oborotu Narcotikov. Materialy Vserossiyskoy Nauchno-
Prakticheskoy Konferencii 15-16 Dekabrya 2009 G. Murino: SZ IPK FSKN Rossii; 2010. p. 182-6.

292. Juglyand YuM. Teoriya i Praktika Khronaksimetrii. Leningrad; 1938.

293. Ushman G. Opredelenie Ernstom Gekkelem ponyatiya «ekologiya». In: Ocherki Po Istorii Ekologii. Moscow: Nauka; 1970. p. 10-21.

294. Fedorov AYa, Fedorov AA. Dva Goda v Sayanah. Moscow: Geografgiz; 1951.

295. Fedorov AyA, Pimenov MG. Hemosistematika, ee problemi i prakticheskoe znachenie. Soobschenie 1. Rastitelnie Resursi. 1967;3(1):3-16.

296. Fedorov AyA, Pimenov MG. Hemosistematika, ee problemi i prakticheskoe znachenie. Soobschenie 2. Rastitelnie Resursi. 1970;6(1)):17-25.

297. Fedorov LYu. Rasskazi o Yadah, Protivyadiyah, Lekarstvah I Uchenykh. Moscow: Znaniye; 1983.

298. Fleming NF, Potter D, Kettil S. Zloupotrebleniye narkoticheskimi veschestvami $\mathrm{i}$ pristrastie $\mathrm{k}$ jupotreblenie narkoticheskikh veschestv. In: Narkologiya. Moscow: Binom; 1988. p. 15-26.

299. Freud Z. Po tu storonju principa udovolstviya proizvedeniy. In: Freud Z. Psikhologiya Bessoznatelnogo. Moscow: Prosvescheniye; 1990. p. $382-424$.

300. Frolova N, Hallberg T, Zazulin G. Praktika Antinarkoticheskoi Deyatelnosti Gorodov i Napravleniya Yeyo Sovershenstvovaniya. Vypusk 1. Moscow: Orbita-M; 2005.

301. Frolova NA, Zazulin GV. Aktjualnye Voprosy Antinarkoticheskoy Politiki: Otechestvenniy i Zarubezhniy Opyt. Nauchno-Prakticheskoe Izdaniye. Moscow, Saint Petersburg; 2003.

302. Furst DB. Nevrotik, Yego Sreda i Vnutrenniy Mir. Moscow: Izd-vo Inostrannoy Literatury; 1957.

303. Hageman P. Plasmaticheskaya Nasledstvennost. Moscow: Izd-vo Inostrannoy Literatury; 1962.

304. Karabet KV. K voprosu o razrabotke koncepcii narkoticheskoy bezopasnosti. In: Deyatelnost Pravoohranitelnikh Organov i Specialnikh Sluzhb v Sfere Protivodeystviya Nezakonnomju Oborotu Narkotikov: Voprosi Organizacii, Koordinacii, Vzaimodeystviya i Mezhdunarodnogo Sotrudnichestva. Materialy Mezhdunarodnoy Najuchno-Prakticheskoy Konferencii 15-16 Dekabrya 2010 Goda. Murino: SZ IPK FSKN Rossii; 2011. p. 222-8.

305. Harper P. Prakticheskoe Mediko-Geneticheskoe Konsultirovaniye. Moscow: Meditsyna; 1984.

306. Khudoley VV, Balanski RM. Kurenie tabaka kak faktor onkologicheskogo riska. Voprosy Onkologii. 1989;(11):1283-90.

307. Chebotar AA, Botnarenko PM. Durman, Sistematika, Biologiya Razvitiya, Mutagenez. Kishinev: Shtiinza; 1978.

308. Cherkesov VV, Mihailov AG, Harichkin ON, Celinsky BP, Peschanskikh GV, Sapovskiy MM, Mironov AS, Nesterov VN, Kashinzev SV, Starodjubov VI, Kakorina VP, Egorov VF, 
Chereshnev VA, Rossel EE, Kovaleva GA, Samkova NP, Djuhova NI, Tatarkin AI, Kuklin AA, Kalina AV, Nifantova RV, Bistray GV, Gurban IR, Komarvskaya AA, Mihailova JuV, Son IM, Meisner AF, Leonov SA, Bogatirev LL, Mizin AL, Levchenko RJu, Diachkov AA, Teterina IG, Klevakin AN, Shmakova IV, Gribanova TN, Shtol AV, Ruzhnikov JuN, Serdjuk JuV. Narkoimmunitet Regiona: Sotsyalno-Ekonomicheskiy i Mediko-Biologicheskiy Aspekt. Moscow: Ekonomika; 2004.

309. Chernukh AM, Aleksandrov PN, Alekseev OV. Mikrotsyrkulyatsiya. Moscow: Meditsyna; 1975.

310. Shabanov PD. Rukovodstvo po Narkologii. Saint Petersburg: Lan; 1998.

311. Shabunin DA. Realnost polucheniya biomassi producentov kannabinoidov $\mathrm{v}$ usloviyakh in vitro. Zhizn Bezopasnost Ekologiya. 2009;(34):187-9.

312. Charikov KE. Kak Sozdavalis Kulturnye Rasteniya. Minsk: Urazhay; 1976.

313. Sheinerman NM, Sirovezhko NV, Slepyan EI. Ob otsutstvii blastomogennikh uglevodorodov V «mumie» i v preparate «NAS». In: Slepyan EI, ed. Rasteniya i Khimicheskie Kantserogeny. Leningrad: Nauka; 1979. p. 144-6

314. Shor GV. O Smerti Cheloveka. Vvedeniye v Tanatologiyu. Saint Petersburg; 2002.

315. Shtern K. Osnovy Genetiki Cheloveka. Moscow: Meditsyna; 1965.

316. Scherbich AN. Opredelenie profilaktiki vozniknoveniya chrezvichainih, svyazannikh s nezakonnim oborotom narkotikov. In: Teoriya i Praktika Protivodeistviya Nezakonnomu Oborotu Narkotikov. Materialy Vserossiyskoy Nauchno-Prakticheskoy Konferencii 15-16 Dekabrya 2009 Goda. Chast 2. Murino: SZ IPK FSKN Rossii; 2010. p. 84-91.

317. Scherbich AN. Opyt protivodeystviya shvedskogo obschestva narkoepidemii. In: Antinarkoticheskaya politika: Shvedskie Otveti $\mathrm{Na}$ Rossiyskiye Voprosy. Saint Petersburg: Iz-vo SPbGU; 2008. p. 187-96.
318. Belyakov NA, ed. Enterosorbtsiya. Leningrad: Tsentr Sorbtsyonnykh Tekhologiy; 1991.

319. Elpis SD, Dzhenvein T, Reynberg D, eds. Epigenetika. Moscow: Tekhosfera; 2010.

320. Anonimous. Epilepsiya izlechivaetsya. Zhizn i Bezopasnost. 1999;(3-4):334-40.

321. Epshteyn AL. Nevroticheskaya Konstitutsiya (Obschaya Chast). Leningrad: Prakticheskaya Meditsyna; 1927.

322. Efroimson VP. Vvedenie v Medicinskuyu Genetiku. Moscow: Meditsyna; 1968.

323. Yudin TI. Psikhopaticheskiye Konstitutsii. Vydeleniye Tipov Kharaktera (Tipov Slozhnykh Psikhicheskikh Reaktsiy) na Osnovanii Nasledstvenno-Biologicheskogo i Klinicheskogo Analiza Psikhozov. Moscow: Izdaniye M i S Sabashnikovykh; 1926.

324. Yunusov SYu. Alkaloidy. Tashkent: FAM; 1974.

325. Yanin BT. Osnovi Tafonomii. Moscow: Nedra; 1983.

326. Yasan EV. «Kompleks vini» (kinoscenariy). Zhizn Bezopasnost Ekologiya. 2009;(1-2):291-315.

327. Yasters K. Obschaya Psikhopatologiya. Moscow: Praktika; 1997.

328. Zazulin GV, ed. Sojuz «Za Obschestvo bez Narkotikov». Saint Petersburg: Izd-vo SPbGU; 2001.

329. Haeckel E. Generelle Morphologie der Organismen. Allgemeine Grundzüge der Organishcen Formen Vissenschaft, mechanisch begründet dürch die von Charles Darvin reformierte Deszendent Theorie. Band II. Entvickelung Geschichte der Organismen. Berlin: Verlag von G. Reimer; 1866.

330. Jamasaki E, Ames BP. Concentration of mutagens from urine by adsorption by nonpolar resin XAD-2. Cigarette smokers have mutagenic urine. Proc Natl Acad Sci USA, 1977;(74)3555-9.

331. Moyer KE. The Psychobiology of Aggression. New York: Harper and Row Publ. 1976.

332. Scott YP. Aggression. Chicago: Univ Chicago Press; 1975.

333. Valzelli L. Psychopharmacology of aggression. Int Phatmacopsychiatry. 1981;(16):39-48.

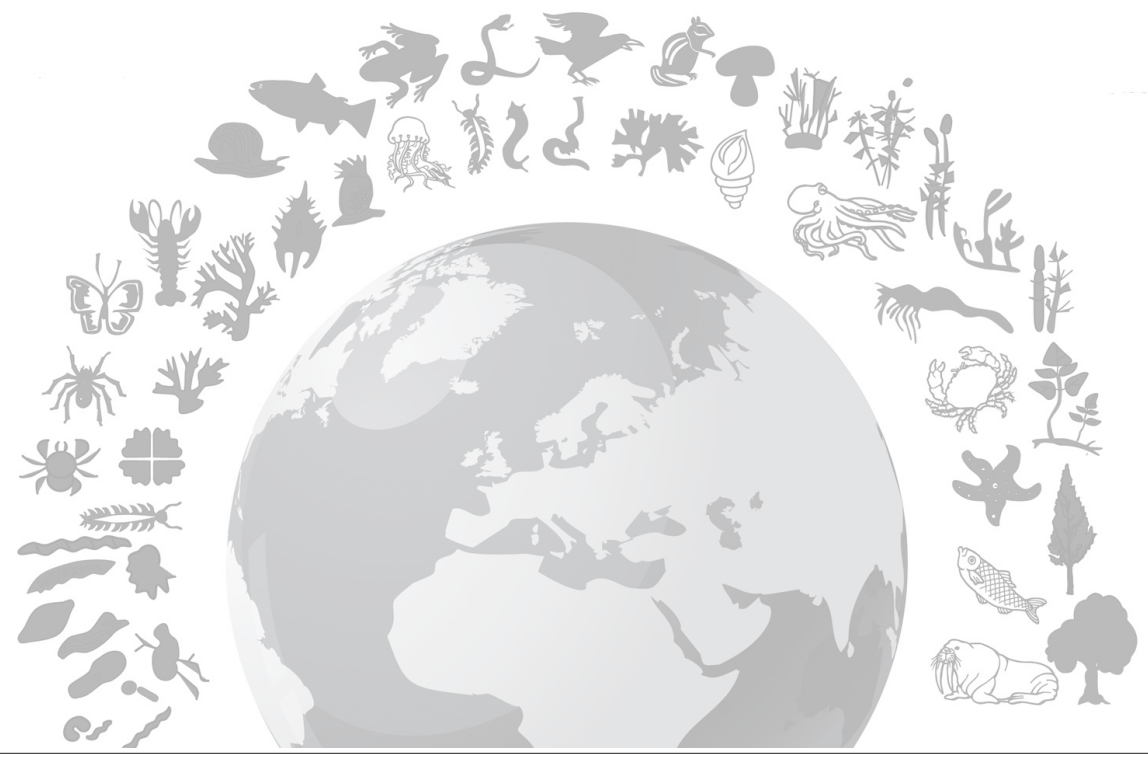

